San Jose State University

SJSU ScholarWorks

Master's Theses

Master's Theses and Graduate Research

Spring 2013

\title{
Foraging behavior, habitat, health, and survival of resident and translocated Hawaiian monk seals at Nihoa Island, Hawaii
}

Tenaya A. Norris

San Jose State University

Follow this and additional works at: https://scholarworks.sjsu.edu/etd_theses

\section{Recommended Citation}

Norris, Tenaya A., "Foraging behavior, habitat, health, and survival of resident and translocated Hawaiian monk seals at Nihoa Island, Hawaii" (2013). Master's Theses. 4301.

DOI: https://doi.org/10.31979/etd.ectv-a4u4

https://scholarworks.sjsu.edu/etd_theses/4301

This Thesis is brought to you for free and open access by the Master's Theses and Graduate Research at SJSU ScholarWorks. It has been accepted for inclusion in Master's Theses by an authorized administrator of SJSU ScholarWorks. For more information, please contact scholarworks@sjsu.edu. 
FORAGING BEHAVIOR, HABITAT, HEALTH, AND SURVIVAL OF RESIDENT AND TRANSLOCATED HAWAIIAN MONK SEALS AT NIHOA ISLAND, HAWAII

A Thesis

Presented to

The Faculty of Moss Landing Marine Laboratories

San José State University

\author{
In Partial Fulfillment \\ of the Requirements for the Degree \\ Master of Science
}

by

Tenaya A. Norris

May 2013 
(C) 2013

Tenaya A. Norris

\section{ALL RIGHTS RESERVED}


The Designated Thesis Committee Approves the Thesis Titled

FORAGING BEHAVIOR, HABITAT, HEALTH, AND SURVIVAL OF RESIDENT AND TRANSLOCATED HAWAIIAN MONK SEALS AT NIHOA ISLAND, HAWAII

by

Tenaya A. Norris

APPROVED FOR MOSS LANDING MARINE LABORATORIES SAN JOSÉ STATE UNIVERSITY

May 2013

Dr. James T. Harvey

Dr. Michael H. Graham

Dr. Frances M.D. Gulland

Dr. Charles L. Littnan

Dr. Scott A. Shaffer
Moss Landing Marine Laboratories

Moss Landing Marine Laboratories

The Marine Mammal Center

NOAA Pacific Islands Fisheries Science Center

Department of Biological Sciences 


\begin{abstract}
FORAGING BEHAVIOR, HABITAT, HEALTH, AND SURVIVAL OF RESIDENT AND TRANSLOCATED HAWAIIAN MONK SEALS AT NIHOA ISLAND, HAWAII

by Tenaya A. Norris

Translocations aimed at promoting population recovery for threatened and endangered species also can function as forced dispersals. To assess the efficacy of translocating Hawaiian monk seals (Monachus schauinslandi) and examine post-dispersal effects on monk seals, in 2008-2009, 12 weanling seals were translocated from French Frigate Shoals (FFS) to Nihoa Island (NIH). In addition, nine adult and eight weanling resident seals were captured at NIH. Satellite instrument attachment, biological sampling, and morphometry were conducted on seals at capture. Focal video camera drops also were conducted at 45 sites around $\mathrm{NIH}(<100 \mathrm{~m})$ in 2010-2011. Translocated and resident weanlings primarily dove to $40-60 \mathrm{~m}$ and used sandy-bottomed habitat $<13$ $\mathrm{km}$ from NIH. In contrast, resident adults had greater variability in foraging behavior and habitat use. There also was a low prevalence of infectious disease in translocated and resident seals, excluding Chlamydophila abortus and enteric bacteria. First-year survival was greater for translocated weanlings $(50 \%, \mathrm{n}=12)$ than non-translocated weanlings at FFS $(31 \%, n=36)$ but was slightly less than non-translocated weanlings at NIH $(69 \%, n$ =16). The results of this study supported four main conclusions that have important consequences on population-level trends: 1) translocations are a viable conservation strategy for monk seals, 2) there was a low risk of spreading pathogens, 3) an abundance of benthic monk seal foraging habitat may exist at NIH, and 4) individuals that disperse with limited foraging experience may adapt rapidly to their post-dispersal habitat.
\end{abstract}




\section{ACKNOWLEDGMENTS}

This project would not have been possible without the support and funding of the NOAA Pacific Islands Fisheries Science Center Hawaiian Monk Seal Research Program and The Marine Mammal Center, including the Geoffrey Hughes Fellowship. The Donald M. Slager Sunset Foundation and the David and Lucile Packard Research and Travel Grant also generously provided project funding.

I sincerely thank my committee members: Jim Harvey, Frances Gulland, Charles Littnan, Mike Graham, and Scott Shaffer. Thank you Jim for encouraging me to be a self-sufficient scientist and for always providing tremendously helpful discussions and feedback when I was feeling overwhelmed or stuck. To Frances, your support and belief in my abilities have largely gotten me where I am today, and I can't thank you enough for everything you've done for me over the years. Thank you Charles for trusting me with this project, ensuring all the fieldwork happened (and keeping me in the dark when things looked questionable), and for being a patient and supportive mentor. Thank you Mike for always being willing to talk about my project and for your constant enthusiasm. Scott, thank you for helping me navigate the complicated world of spatial statistics and for putting me in touch with others that also helped me in this area. I have learned so much from each one of you and am grateful you all agreed to be on my thesis committee.

In addition, thank you Denise Greig for being an amazing mentor and friend since you first introduced me to the world of marine science. To Sara Maxwell and Carey Kuhn, thank you both for helping me understand the intricacies of working with spatial data. 
There were so many fantastic people that helped with the fieldwork portion of this project and I thank each one of you: Bob Braun, Chad Yoshinaga, Sean Guerin, Mark Sullivan, Shawn Farry, Monica Bond, Derek Lee, Erin Moreland, Jason Jones, Scott Ferguson, Stephanie Floyd, Kenady Wilson, Jessie Lopez, Tracy Wurth, Angie Kaufmann, Jennie Schultz, Gretchen Johnson, Sarah Chinn, Colleen Siudzinski, Lisa White, Marie Chapla, Kathleen Gobush, Heather Harris, Amanda Boyd, Kelaulani Souza, Walterbea Aldeguer, and Jamie Barlow. I am grateful to all the people that provided additional project support: Liz Kashinsky, Thea Johanos-Kam, Jason Baker, Frank Parrish, Brenda Becker, Bert Harting, Darin Padula, Spencer Jang, Hon Ip, Tracey Goldstein, Sam Simmons, the officers and crew of the NOAA Ship Oscar Elton Sette, and the Littenberg family and crew of the M/V Searcher. I am fortunate to call many of you friends and truly appreciate all your support of this project.

And last, but certainly not least, thank you to my family for always being my biggest supporters. Mom and Dad, thank you for always encouraging me to pursue my dreams. Thank you Coral for always being so understanding and helping me keep things in perspective. To Brandon, your unconditional love and patience have kept me afloat during this journey. 


\section{TABLE OF CONTENTS}

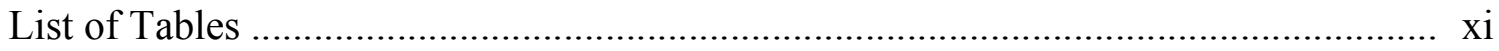

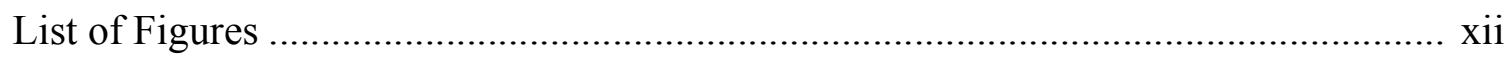

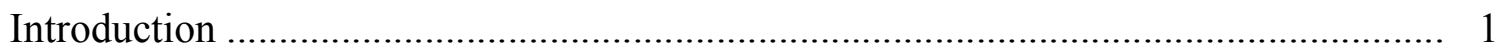

Materials and Methods ................................................................................... 5

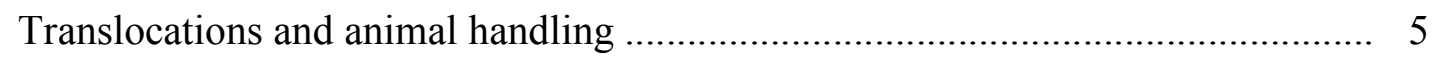

Satellite instrument programming and data processing ................................ 7

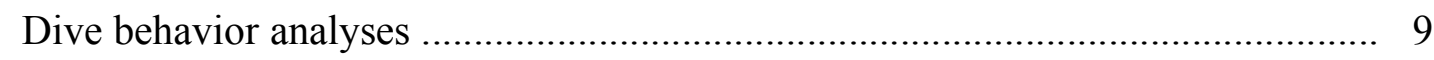

Horizontal spatial use analyses ........................................................... 9

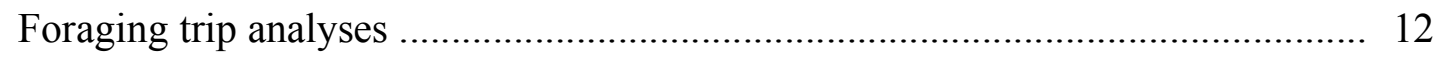

Foraging habitat use analyses ............................................................ 12

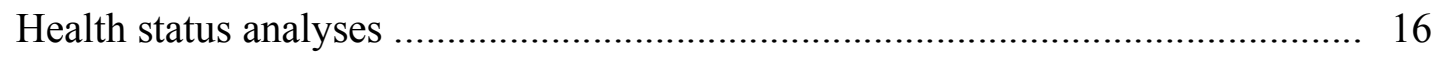

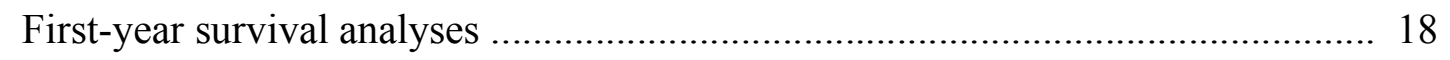

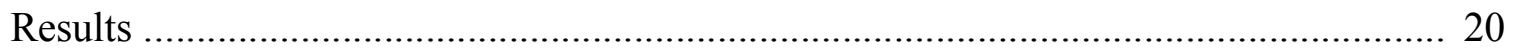

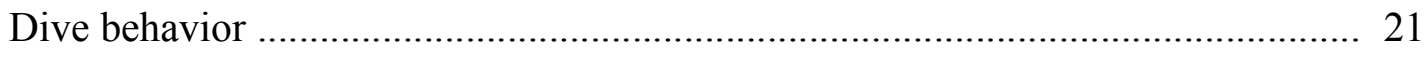

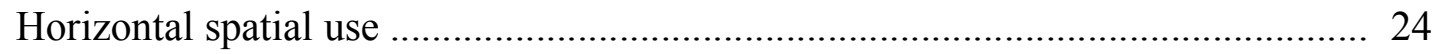

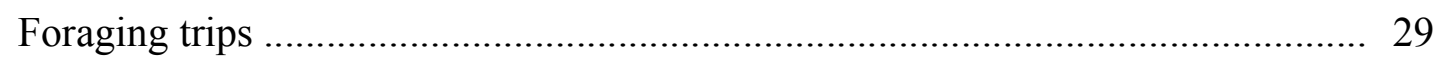

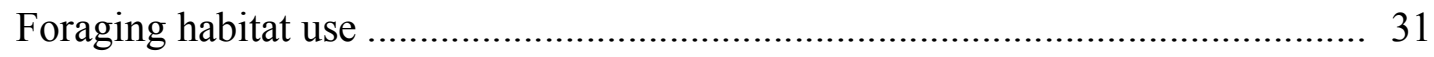

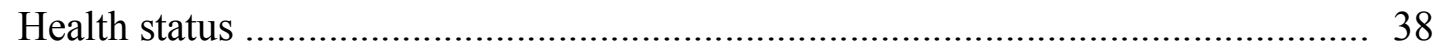

Re-sights and first-year survival .......................................................... 43

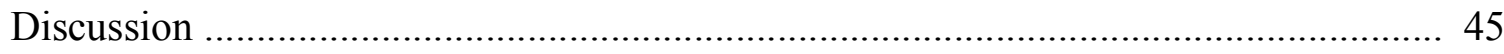

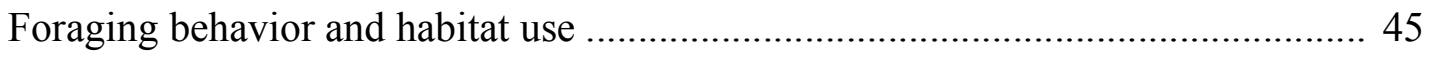


Health status 51

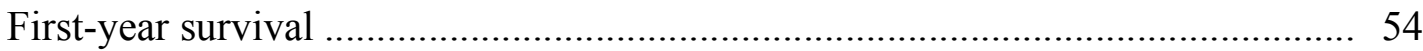

Conclusions ….................................................................................. 56

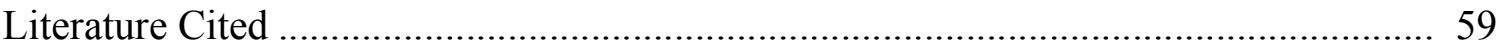

Appendix 1. Weaning and pre-translocation capture data for weanling seals

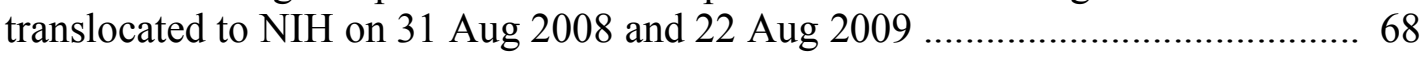

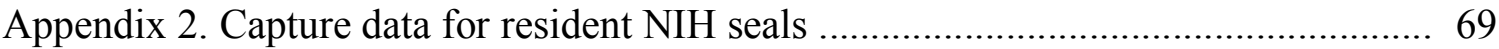

Appendix 3. Fast-GPS filtering algorithm steps ........................................... 70

Appendix 4. Spatial grid cell methods to create utilization distributions (UDs) ........... 71

Appendix 5. Summary of 28 video camera drop sites on NIH terrace ........................ 72

Appendix 6. Summary of 17 video camera drop sites on WNB terrace ....................... 73

Appendix 7. Manual techniques used to perform complete blood counts and partial

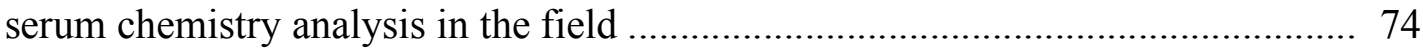

Appendix 8. Post-weaning acclimation period summary …................................ 75

Appendix 9. Satellite tracking summary for individuals excluded from analyses ........ 76

Appendix 10. Filtered Fast-GPS locations for individuals excluded from analyses ..... 77

Appendix 11. Satellite tracking summary for individuals included in analyses ............ 78

Appendix 12. Maximum dive depth and duration bins used by each individual ........... 80

Appendix 13. TW seals' dive depth frequency histograms for each six-hour period ..... 81

Appendix 14. RW seals' dive depth frequency histograms for each six-hour period .... 82

Appendix 15. RA seals' dive depth frequency histograms for each six-hour period .... 83

Appendix 16. Individual dive depth frequency histograms ................................... 84

Appendix 17. TW seals' time-at-depth frequency histograms for each six-hour period 85 
Appendix 18. RW seals' time-at-depth frequency histograms for each six-hour period 86

Appendix 19. RA seals' time-at-depth frequency histograms for each six-hour period 87

Appendix 20. Individual time-at-depth frequency histograms ..................................... 88

Appendix 21. TW seals' dive duration frequency histograms for each six-hour period 89

Appendix 22. RW seals' dive duration frequency histograms for each six-hour period 90

Appendix 23. RA seals' dive duration frequency histograms for each six-hour period 91

Appendix 24. Individual dive duration frequency histograms ..................................... 92

Appendix 25. Filtered Fast-GPS locations for TW seals ............................................. 93

Appendix 26. Filtered Fast-GPS locations for RW seals .............................................. 94

Appendix 27. Filtered Fast-GPS locations for RA seals ............................................. 95

Appendix 28. Interpolated locations with two-hour sampling interval ........................ 97

Appendix 29. Utilization distributions (UDs) for TW seals .......................................... 98

Appendix 30. Utilization distributions (UDs) for RW seals .......................................... 99

Appendix 31. Utilization distributions (UDs) for RA seals ......................................... 100

Appendix 32. Percentage utilization distribution versus percentage area plots to determine dividing point between home range core and periphery for TW seals .. 102

Appendix 33. Percentage utilization distribution versus percentage area plots to determine dividing point between home range core and periphery for RW seals .. 103

Appendix 34. Percentage utilization distribution versus percentage area plots to determine dividing point between home range core and periphery for RA seals .. 104

Appendix 35. Home range (HR) and core area summary statistics for each seal ......... 105

Appendix 36. Percentage utilization distribution versus percentage area plots to determine dividing point between home range core and periphery for each group 106

Appendix 37. Foraging trip statistics for each individual 107 
Appendix 38. Habitat classifications for 28 camera drop sites on NIH terrace 108

Appendix 39. Habitat classifications for 17 camera drop sites on WNB terrace

Appendix 40. Relationship between depth and proportion of locations per area of influence for resident adults (RA) and all seals combined

Appendix 41. Hematology statistics for wild monk seals translocated and resident to $\mathrm{NIH}$

Appendix 42. Hematology values for each individual

Appendix 43. Serum chemistry statistics for wild monk seals translocated and resident to NIH

Appendix 44. Serum chemistry values for each individual

Appendix 45. Last sighting date and location for re-sighted translocated and resident monk seals

Appendix 46. Discriminant function scores for weaning body size

Appendix 47. Relationship between girth and first-year survivorship 120

Appendix 48. First-year survivorship models for subset of weanling seals with axillary girth $(\mathrm{AG}) \geq 97 \mathrm{~cm}$ 


\section{LIST OF TABLES}

Table 1. Group home range (HR) and core area summary statistics ......................... 27

Table 2. Core and home range (HR) area overlap between groups of seals ................. 29

Table 3. Generalized linear models that best predicted foraging habitat use of each group of seals for the three surface texture variables ....................................... 34

Table 4. Generalized linear model coefficients $(B)$ for each group's best fitting habitat use model ............................................................................... 35

Table 5. Prevalence of infectious agents or antibodies to them ................................. 41

Table 6. Prevalence $(\%)$ of enteric bacteria ....................................................... 42

Table 7. First-year survivorship models ............................................................. 45 


\section{LIST OF FIGURES}

Figure 1. Hawaiian Archipelago ....................................................................... 6

Figure 2. Group modal diving activity .............................................................. 23

Figure 3. Group utilization distributions (UDs) ................................................ 28

Figure 4. Group foraging trip statistics ......................................................... 30

Figure 5. Surface texture classifications for camera drop sites ................................ 32

Figure 6. Relationship between each term in the best fitting habitat use models and proportion of locations per area of influence ................................................... 36

Figure 7. Values for blood parameters selected as broad indicators of health ............... 39 


\section{INTRODUCTION}

In wild animal populations, natural dispersal of individuals may influence genetic structure and spatial distribution patterns of a population (Bowler \& Benton 2005, Clobert et al. 2012) and contribute to the spread of pathogens (Hess 1994, Dietz et al. 2012). Dispersal also may have important consequences on individual fitness and consequently population dynamics (Clobert et al. 2012). To examine the effects of dispersal on individual fitness, the survival and reproduction of dispersing and philopatric, or non-dispersing, individuals often are compared, but there are many practical limitations associated with the empirical study of dispersal (Bélichon et al. 1996, Kokko \& López-Sepulcre 2006). For example, it is difficult to simultaneously sample dispersing individuals at the time of settlement and philopatric individuals at the dispersal site because the destinations of naturally dispersing individuals are unpredictable and variable. Thus, dispersal studies often are theoretical and use modeling approaches to predict population-level effects of dispersal (Bowler \& Benton 2005). Another way to overcome the practical problems of studying dispersal is the use of a manipulative experiment that intentionally moves individuals to an unfamiliar location (Bélichon et al. 1996, Kokko \& López-Sepulcre 2006).

This approach of deliberating moving wild individuals from one location in their geographic range to another also is the definition of "translocation" in the context of wildlife management (IUCN 1998). As a commonly used wildlife management tool, the results of translocation studies typically are interpreted in the context of program success (Griffith et al. 1989, Wolf et al. 1996, Fischer \& Lindenmayer 2000). The outcome of 
many translocation programs, however, are uncertain because no standardized criteria for judging translocation success exist or the criteria for success, both short and long term measures, are not explicitly stated (IUCN 1998, Fischer \& Lindenmayer 2000, Sheean et al. 2012). Some criteria of translocation success include the immediate post-release survival of translocated individuals (Reinert \& Rupert 1999, Calvete \& Estrada 2004), establishment of a self-sustaining population (Griffith et al. 1989, Gusset et al. 2009), or demonstration of positive population growth (Matson et al. 2004). In addition, until recently, few translocation studies implemented experimental approaches with testable hypotheses and robust post-release monitoring (Fischer \& Lindenmayer 2000, Sheean et al. 2012). Despite the inconsistent assessment of program success, avian and terrestrial mammal translocations have been applied widely for a variety of purposes, one of which is reducing the risk of extinction for threatened and endangered species (e.g., Gusset et al. 2009, Reynolds et al. 2008). Conversely, there are few instances in which this conservation strategy has been used to promote the population recovery of marine mammals, with the exception of the sea otter (Enhydra lutris; Jameson et al. 1982) and Hawaiian monk seal (Monachus schauinslandi; Baker et al. 2011).

Hawaiian monk seals are critically endangered with a population of less than 1,200 individuals (Carretta et al. 2012). Since 1998, monk seal abundance has decreased at an annual rate of approximately $4 \%$ in the Northwestern Hawaiian Islands (NWHI; Carretta et al. 2012). Multiple factors have contributed to the NWHI monk seal population decrease, including shark predation, male aggression, marine debris entanglement, fisheries interaction, and disease (Banish \& Gilmartin 1992, Antonelis et 
al. 2006, Bertilsson-Friedman 2006). Extremely poor juvenile survivorship that has been linked to prey limitation, however, is considered the primary cause of the continued decrease in monk seal numbers (Craig \& Ragen 1999, Baker 2008). With its endangered status and continued population decrease, translocations have been used as an important monk seal conservation strategy to mitigate some of these sources of mortality (Baker et al. 2011). These include moving monk seal pups at French Frigate Shoals (FFS) that are at greater risk of Galapagos shark predation and adult males that display aggression towards conspecifics. In contrast, few monk seal translocation efforts have addressed the problem of prey limitation in the NWHI (Baker et al. 2011).

Juvenile monk seal survivorship varies in time and space in the NWHI and has been linked to ocean productivity (Schmelzer 2000, Baker \& Thompson 2007, Baker et al. 2007). The three southern-most NWHI - FFS, Necker Island (NEC), and Nihoa Island (NIH) - have similar oceanographic conditions (Schmelzer 2000, Desch et al. 2009) but different juvenile monk seal survival trends. Whereas juvenile monk seals at FFS have experienced $80 \%$ mortality in some years (Baker \& Thompson 2007), the monk seal populations at NEC and especially NIH appear to be increasing although they have been relatively understudied (Carretta et al. 2012). Monk seals at NEC and NIH also are in better body condition than conspecifics elsewhere in the NWHI (Baker \& Johanos 2004), and body condition and survivorship are correlated for juvenile monk seals (Craig \& Ragen 1999, Baker 2008). Because monk seals are opportunistic benthic and demersal foragers that use isolated summits of the Hawaiian ridge (Parrish et al. 2000, 2002, 2005, Stewart et al. 2006), the availability of suitable benthic foraging habitat for monk seals in 
their diving depth range $(<500 \mathrm{~m})$ may be a limiting resource that affects prey availability in addition to ocean productivity. Although the availability of suitable benthic foraging habitat for monk seals at NIH had not been examined, the limited data available indicate food resources may not be limiting population growth at this NWHI site in particular. Thus, translocating juvenile monk seals to NIH may improve their probability of survival as a result of improved foraging conditions. Conversely, the extremely poor survivorship of weanling monk seals at FFS and their young age, which has been associated with greater fidelity to the release site (Baker et al. 2011), make them ideal translocation candidates.

Here, in addition to assessing the short-term efficacy of translocating weanling monk seals within the NWHI from FFS to NIH, translocation also was considered to be synonymous with experimental dispersal (Stamps \& Swaisgood 2007) to examine how dispersal may affect aspects of the biology and ecology of monk seals. Specifically, the consequences of translocation and dispersal on the foraging behavior, habitat use, risk of spreading pathogens, and survival of monk seals were examined. The following hypotheses were tested. Translocated (dispersing) and resident (philopatric) seals at NIH were expected to primarily use shallow-water $(<200 \mathrm{~m})$ habitats with limited diving to subphotic depths (Parrish et al. 2000, 2002, 2005, Stewart et al. 2006). The foraging behavior and habitat use of translocated and resident NIH monk seals were hypothesized to reflect age-related differences in spatial use (Draulans \& Van Vessem 1985, Merrick \& Loughlin 1997). In particular, I expected more restricted foraging ranges for weanling seals compared with adults, immature seals to primarily forage in deep sand fields, and 
adult seals to use a variety of benthic foraging habitats (Parrish et al. 2000, 2002, 2005, Stewart et al. 2006, Cahoon 2011). The health status of translocated and resident monk seals at NIH was expected to be similar with a low prevalence of infectious disease (Aguirre et al. 2007, Littnan et al. 2007). Thus, the risk of spreading diseases as a result of translocation or dispersal was hypothesized to be minimal. With the expectation of improved foraging conditions at NIH, greater first-year survival was hypothesized for translocated and resident weanling seals at NIH relative to weanling seals that remained at FFS. As the first comprehensive study of the monk seal population and environment conditions at NIH, this study also provided a unique opportunity to gain additional insight into the factors that may be contributing to the decreasing abundance of Hawaiian monk seals and affecting population recovery efforts.

\section{Materials ANd Methods \\ Translocations and animal handling}

Twelve weanling monk seals were translocated $450 \mathrm{~km}$ from FFS to NIH in late August 2008 and 2009 (Figure 1, Appendix 1). Up to 10 days before translocation, weanling seals were captured for satellite instrument attachment, biological sampling, and morphometric measurements. Translocated seals were transported from FFS to NIH in cages via the NOAA research vessel Oscar Elton Sette (OES) and between the OES and each site in stretcher nets aboard small boats. During the $\leq 46.5 \mathrm{~h}$ transport, translocated seals were monitored continuously, but seals did not receive food or medical treatment. Translocated seals were released within $100 \mathrm{~m}$ of NIH because landing on the 
single beach was not logistically possible. In addition, 17 adult and weanling monk seals were captured at NIH (residents) in September 2008 and 2009 for instrumentation, sampling, and measurements (Appendix 2). Only one subadult seal was captured at NIH, and this seal was grouped with resident adult (RA) seals for all analyses.

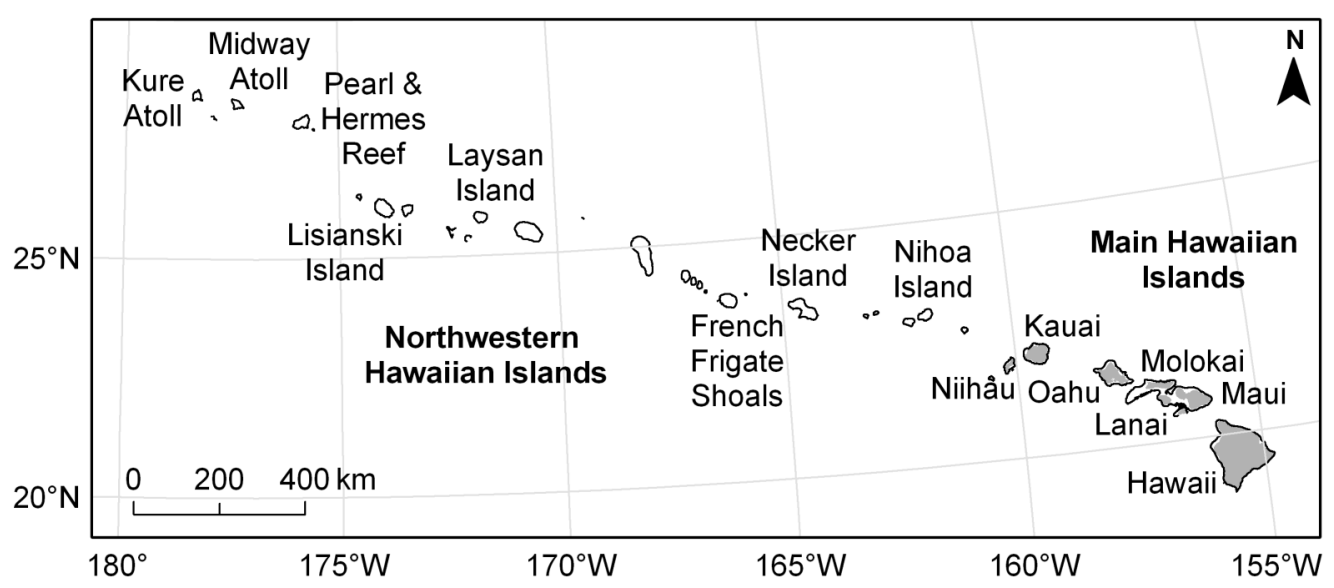

Figure 1. Hawaiian Archipelago. Nihoa Island is the southern-most Northwestern Hawaiian Island. Grey shading represents land, and black lines indicate the 200-m isobath.

All seals were captured using a hoop net and manually restrained until 0.1-0.2 $\mathrm{mg} / \mathrm{kg}$ of intravenous diazepam was administered. Blood was collected from the extradural vein into ethylene-diaminetetraacetic acid (EDTA), sodium heparin, and serum separator blood collection tubes (Becton, Dickinson and Company, Franklin Lakes, NJ). Dry swabs from the nares and rectum were collected and stored in viral transport media (VTM). Fecal samples were collected by rectal swab that were placed in modified Cary Blair media (C\&S Medium, Medical Chemical Corporation, Torrance, CA). Biological samples were stored at $4^{\circ} \mathrm{C}$ until processing. These samples were not collected from any resident weanling seals in 2008 due to logistical constraints. Axillary girth (AG) and 
dorsal standard length (DSL; $\pm 0.5 \mathrm{~cm}$ ) were determined for each seal, and all weanling seals also were weighed $( \pm 0.2 \mathrm{~kg})$ using a tripod and digital hanging scale. A satellitelinked time-depth recorder with a global positioning system (GPS; Mk10-AF Transmitting Fast-GPS tag, Wildlife Computers, Redmond, WA) was attached to the dorsal pelage between the shoulders using Devcon 10-Minute Epoxy (ITW Devcon, Danvers, MA).

\section{Satellite instrument programming and data processing}

Each satellite instrument was programmed to transmit 150-250 times per day during periods when orbiting NOAA satellites were in position to receive transmissions. If the wet/dry sensor was dry for $\geq 10 \mathrm{~min}$, the instrument switched to haul-out mode with a reduced transmission rate. To conserve battery power, transmissions paused when the tag was dry for more than two hours. The Mk10-AF satellite tags transmitted dive summaries binned into 14 frequency histograms for four 6-h periods of the day. Period start times were 00:00, 06:00, 12:00, and 18:00 local time (GMT - $10 \mathrm{~h}$ ). Dive summaries included the number of dives per maximum depth bin achieved per dive, number of dives in each duration bin, and proportion of time spent in each depth bin (time-at-depth, TAD). Histogram dive data were sampled every $10 \mathrm{~s}$. Dives $<2 \mathrm{~m},<30$ s (2008 data), and < 1 min (2009 data) were ignored for dive depth and duration but not TAD. Mk10-AF tags also use Fastloc ${ }^{\mathrm{TM}}$ technology (Wildtrack Telemetry Systems Ltd.) to rapidly acquire accurate GPS locations during seal surfacings. Error estimates were $<$ $140 \mathrm{~m}$ for $95 \%$ of GPS fixes when a signal was received by at least five satellites (Bryant 2007). Fast-GPS locations were attempted at 10-min intervals with a maximum of four 
successful (signal received by $\geq$ four satellites) and three failed transmissions per hour (maximum of 96 successful and 100 failed transmissions per day). Location data were transmitted as the top priority. Only Fast-GPS location and dive histogram data, transmitted via the Argos Data Collection and Location Service (Collecte Localisation Satellites 2008), were used because transmitter recovery was not possible in most cases. Transmitted data were extracted using Wildlife Computers's Data Analysis Program (WC - DAP) version 44.

Telemetry data from all weanling seals were processed to exclude the immediate post-weaning period in which their diving activity and movement patterns were restricted to habitats within $2.5 \mathrm{~km}$ of $\mathrm{NIH}$ (depth $<40 \mathrm{~m}$ ) because it was unlikely they were feeding regularly during this time. The post-weaning acclimation period was defined separately for each weanling seal as having ended when the seal first dove $>40 \mathrm{~m}$ deep and moved away from NIH for $>$ one day. The acclimation period duration was calculated using the weaning date for each translocated weanling (TW) seal. Because seven resident weanling (RW) seals had unknown weaning dates, the period from capture date to end of the post-weaning acclimation period also was calculated for each weanling seal. Additionally, telemetry data from the end of tracking periods that had extremely reduced transmission rates were excluded from all analyses. This resulted in the loss of $\leq$ 15 transmissions for three RA seals. All telemetry and other data processing were conducted in MATLAB 7.14 (Mathworks, Natick, MA) using custom-written and built-in codes. 


\section{Dive behavior analyses}

The 14 dive depth and duration frequency bins were condensed into six bins to reduce the number of bins with zero values and simplify the interpretation without losing the resolution necessary to investigate differences in diving activity among the three groups of seals (TW, RW, RA). Dives to depths $>80 \mathrm{~m}$ (maximum depth bin: $>350 \mathrm{~m}$ ) were infrequent $(<4 \%$ of dives for all seals). Thus, all bins greater than $80 \mathrm{~m}$ were combined to create six pooled depth bins: $<10,10-20,20-40,40-60,60-80$, and $>80 \mathrm{~m}$. Combined dive duration bins were: $<4$ min (four 1-min bins pooled), 4-6 min (two 1-min bins pooled), 6-7, 7-8, 8-10, and $>10$ min (five duration bins up to maximum bin of $>25$ min contained $5 \%$ of dives for all seals). The proportion of dives per bin was calculated for each dive depth and duration record to standardize for differences in number of dive records received. Mean dive depth, dive duration, and TAD frequency histograms were qualitatively compared among the: 1) four 6-h periods for each seal, 2) individuals within each group, and 3) groups (TW, RW, RA).

\section{Horizontal spatial use analyses}

Fast-GPS locations were filtered to remove outliers using a modified version of the filtering algorithm of Freitas et al. (2008; Appendix 3). Filtered Fast-GPS data were interpolated using the hermite spline method to obtain an equal sampling interval (Tremblay et al. 2006). Interpolated data were used because irregularities in the temporal spacing of satellite telemetry data may result from non-biological reasons or animal behavior that are not related to the study objectives (Fieberg et al. 2010), especially in marine telemetry studies in which satellite transmitters are frequently underwater. A 
two-hour interpolation interval was used because this interval resulted in interpolated data that were not over-sampled but still accurately represented fine-scale movements (Tremblay et al. 2006). Because interpolated tracks were not tangential to every raw location, some fine-scale movements may have been missed.

To examine at-sea horizontal spatial use of translocated and resident seals, the spatial grid cell method was used because it was transparent, easily manipulated, and allowed fine-scale movements and more precise utilization distributions (UDs) to be determined (Maxwell et al. 2011). In contrast, the widely applied kernel density estimator overestimates home range size and over-smoothes results, which was not appropriate for this study given its small spatial scale (Maxwell et al. 2011) and the increased transmission rate and spatial accuracy of GPS data (Kie et al. 2010). Grid cell size and positioning, however, can greatly affect the output, and no standardized method for selecting cell size exists (Kenward 1987). An optimal balance was achieved between making grid cells as small as possible to examine fine-scale movements, yet large enough to produce smooth contours that minimized gaps between used cells (Maxwell et al. 2011). A grid cell of $2 \mathrm{~km}^{2}$ was selected as the optimal size. Additionally, grid cells were positioned by dividing NIH $\left(0.69 \mathrm{~km}^{2}\right)$ in half with two cells longitudinally and centering these two cells on NIH latitudinally to minimize the number of cells with land. Individual and group UDs with 10\% isopleths were generated and represented the probability distribution of finding a seal in a given cell (Appendix 4; Maxwell et al. 2011). UDs representing the combined horizontal spatial use of all weanling seals and all seals also were created. The home range (HR) of each seal or group was defined by the 
95\% UD isopleth, which resulted in more stable HR estimates regardless of grid cell size than HRs including all cells used (100\% UD). Each HR was divided into a core and peripheral area using a more objective approach than the commonly used $50 \%$ UD (Bingham \& Noon 1997, Powell 2000). Briefly, the 10\% UD increment at which seal space use deviated the most from random use (i.e. farthest point on clumped-use curve of best fit in percentage UD versus percentage area plot from 1:1 line of random use) was defined as the dividing point between the HR core and periphery. Core and HR areas were determined for each individual, group, all weanling seals, and all seals combined. Percentage core and home range area overlap among the three groups of seals also were calculated (Robson et al. 2004). Geospatial data were analyzed using the Transverse Mercator projection and World Geodetic System (WGS) 1984 reference ellipsoid in MATLAB's Mapping Toolbox 3.5.

Differences in core and HR area size were tested between groups using twosample independent t-tests because these data met the assumptions of normality and equal variance. For this and all other between-group statistical testing, comparisons were conducted between: 1) weanling seal groups, and 2) adults and weanling seals. All weanling seals were grouped together for the second comparison to improve power and because comparing RW and TW seals separately against RA seals did not change the results. Effect sizes $(r)$ for t-tests were calculated (Cooper \& Hedges 1994). All statistical analyses were conducted using SPSS 20 (IBM Corporation, Armonk, NY). Unless otherwise stated, the significance level was $\alpha<0.05$, and all means were reported along with standard error (SE). 


\section{Foraging trip analyses}

To compare differences in foraging excursions among the three groups, trip distances, relative search index (RSI), duration, and direction were determined. Maximum trip distance was calculated as the great-circle path (GCP) distance from the center of $\mathrm{NIH}\left(23.0606^{\circ} \mathrm{N}, 161.9219^{\circ} \mathrm{W}\right)$ to the farthest GPS location for each trip. Trip direction was calculated as the compass heading along this GCP. Total trip distance was the sum of all straight-line distances between consecutive locations for each trip. RSI was total trip distance divided by maximum trip distance (Call et al. 2008). For all trip statistics, only complete trips with $\geq$ two locations and a total trip distance: 1) $\geq 2 \mathrm{~km}$, or 2) $\geq 4 \mathrm{~km}$ if trip duration was $\leq 4 \mathrm{~h}$ were included. Locations within $100 \mathrm{~m}$ of the island were considered to be on-land. To reduce the number of non-independent statistical tests, only differences in maximum trip distance, RSI, and trip direction were tested using twosample independent t-tests or, when the assumption of equal variance was rejected, randomization tests (10,000 iterations). All data were normally distributed.

\section{Foraging habitat use analyses}

To characterize the benthic habitat around $\mathrm{NIH}$, focal video camera drops were conducted at 45 sites on the terraces $(<100 \mathrm{~m})$ around $\mathrm{NIH}$ and at the bank nine $\mathrm{km}$ to the west of NIH (WNB) using a SplashCam Deep Blue Pro underwater video camera (Ocean Systems, Inc., Everett, WA). Camera drop sites were randomly determined and stratified by depth $(<40,40-60,60-80,80-100 \mathrm{~m})$ and intensity of use (more and less intensely used areas) based on the diving activity and spatial use of resident and 
translocated seals. The northeastern portion of the NIH terrace and western half of the WNB terrace were not surveyed because of their increased distance from the island.

Camera drops were conducted on five days in 2010 and 2011 (Appendices 5-6). At each camera drop site, the vessel platform (OES or M/V Searcher) drifted for one to five minutes with the camera oriented straight down, approximately one meter above the seafloor. The camera often could not be maintained at a distance of one meter off the bottom, even with additional weight attached, and camera distance from the seafloor typically increased throughout the drift (camera kiting). Drift durations were shortened to approximately one minute after an initial series of 13 camera drops demonstrated the benthic habitat was generally homogeneous throughout a five-minute drift. In addition to recording video footage from the time the camera entered the water until it was again on deck, GPS coordinates, vessel depth reading (OES: Simrad ES60 and Searcher: Furuno FCV292), and local time were recorded at the beginning and end of each drift. Drift distances were calculated as the GCP distances between the start and stop coordinates for each drift. Most camera drops $(80 \%)$ covered distances $<100 \mathrm{~m}($ range $=5-500 \mathrm{~m})$.

All video footage was viewed, and the physical and biological benthic habitat was characterized using a modified version of NOAA's Center for Coastal Monitoring and Assessment classification scheme (NOAA 2003). Induration, or the degree of surface hardness, of each site was defined as predominately hard-bottom (HB) or unconsolidated (UN) sediment. Sites were classified as coral colonized ( $>10 \%$ live coral coverage) or uncolonized (0-10\%). The presence of live coral was used to help determine whether sites were primarily HB (i.e. not periodically inundated by soft sediment). Surface 
roughness (rugosity, waviness, and complexity) of each site was categorized as none, low, moderate, or high. Three substrate types were used that combined induration, roughness, and coral colonization: 1) colonized HB (moderate-high roughness) or uncolonized HB with high roughness, 2) uncolonized HB with low-moderate roughness, and 3) UN (none-low roughness). The presence of large geomorphologic features (e.g., rocky ledges, caves, crevices, and overhangs) that often were associated with increased fish and invertebrate density was determined for each site. Because dense aggregations of heart urchins, likely Brissus latecarinatus, were observed in the study area, their presence also was classified. Additionally, macroalgal cover was quantified as sparse ( $<$ $10 \%$ coverage), moderate (10-50\%), or dense (> $50 \%)$.

Bathymetry data for NIH and the nearby banks had large spatial gaps (available at: www.soest.hawaii.edu/pibhmc/). Therefore, using remotely sensed data to estimate depth, slope, aspect, and rugosity at the scale of monk seal habitat use was not possible. Consequently, site depth was calculated by taking the mean vessel depth reading from the beginning and end of each drift. From the video footage, seafloor slope at all but one site (\# 37) was relatively flat; therefore, slope and aspect were not characterized. Rugosity was defined categorically as part of surface roughness. Because of the homogeneity of habitat within a drift, drift (line) data were condensed to point data using the coordinates at the start of the drift. Site distance to NIH was calculated as the GCP distance from the start of the drift to the center of NIH. Direction to NIH along this GCP also was determined for each site. 
To quantify the intensity of monk seal habitat use associated with the sites, a circular area of influence with a radius of $600 \mathrm{~m}$ was created around each site. This radius was used because it likely represented the maximum distance traveled by a monk seal during a dive (duration of $10 \mathrm{~min} *$ swim speed of $1 \mathrm{~m} / \mathrm{s}$, which was the average dive ascent and descent rate for juvenile monk seals; Parrish et al. 2005). Although monk seals likely cover shorter distances during foraging dives to the benthos, this area of influence also accounts for uncertainty associated with using interpolated seal locations and GPS location error estimates. The proportion of interpolated locations within each area of influence was calculated for each seal using that seal's total number of at-sea locations included in the analyses. Mean proportion of locations per area of influence was determined for the three groups (TW, RW, RA) separately and all seals combined with zeros for areas not used.

Generalized linear models (GLMs) were used to examine the effects of location and seafloor geomorphology on monk seal habitat use. GLMs were fitted to the mean proportion of locations per area of influence $\left(1.13 \mathrm{~km}^{2}\right)$ using a compound gamma and Poisson distribution for proportion data with zeros (Tweedie distribution) and log link function. A Tweedie parameter of 1.5 was used for all models. Four separate GLMs were conducted to examine the habitat use of: 1) TW seals, 2) RW seals using the 28 sites on the NIH terrace (NIH-only models); 3) RA seals, and 4) all seals combined using all 45 sites on the NIH and WNB terraces (All-sites models). Correlated continuous predictor variables were not included in the same model. Direction and distance to NIH were negatively correlated for all sites $(r=-0.792, p<0.001)$, whereas distance to NIH 
and depth were correlated for the NIH-only sites $(r=0.702, p<0.001)$. The three surface texture variables (induration, roughness, and substrate) were related and also were not included in the same GLMs. Macroalgal cover, live coral cover, and presence of heart urchin aggregations were excluded from all models because these data were represented within the surface texture variables and were missing for some sites. Therefore, the saturated All-sites models included: induration or roughness or substrate + features + depth + direction or distance, and the saturated NIH-only models included: induration or roughness or substrate + features + direction + depth or distance. The model with the least Akaike's Information Criterion for small sample sizes $\left(\mathrm{AIC}_{\mathrm{C}}\right)$, which penalizes for extra parameters (Burnham \& Anderson 2002), was selected as the best fitting model relative to those with the same null model.

\section{Health status analyses}

Biological samples were processed within six hours of sample collection, except for fecal samples that were maintained at $4^{\circ} \mathrm{C}$ for $6-16$ days until samples could be sent for analysis. To assess the health status of weanling seals before translocation, complete blood counts (CBCs) and partial serum chemistry analyses were performed in the field using manual techniques (Appendix 7). The same manual CBC methods were used for all samples collected from resident NIH seals. Additionally, in 2008, hemoglobin (HGB) concentrations were determined using the cyanmethemoglobin method (VillegasAmtmann \& Costa 2010). For all seals, ETDA blood smears were stored unstained at room temperature (RT) and used to determine white blood cell (WBC) differentials by University of California, Davis (UCD), School of Veterinary Medicine (Davis, CA). 
Serum separator tubes were centrifuged and aliquots of serum, along with the nasal and rectal swabs in VTM, were frozen in liquid nitrogen until these samples could be transferred to a $-80^{\circ} \mathrm{C}$ freezer. An aliquot of frozen serum collected from each seal was sent to IDEXX Laboratories (Sacramento, CA) for serum chemistry analysis.

For 35 blood variables measured, only one creatine kinase (CK) value $(14,771$ U/l) was considered to be an outlier (Schwacke et al. 2009). This value was verified by repeat analysis, and confounding factors that may affect CK concentrations were not noted for this individual (e.g., little struggle under restraint, no sample hemolysis). Therefore, this CK value was retained in the analysis. Mild to severe hemolysis, which affects various blood parameters, was noted for several samples. With the limited sample size and lack of other detectable outliers, all hematology and serum chemistry values from hemolyzed samples were retained in the analysis. Hematology values from one RW seal, however, were excluded because $25 \%$ of the cells on this seal's blood smear were apoptotic, suggesting a collection artifact occurred.

For TW, RW, RA, and all weanling seals, the median and range for each hematology and serum chemistry variable were calculated because blood variables often have asymmetrical distributions. To reduce the number of non-independent tests, four blood parameters were selected as broad indicators of health for statistical comparison: WBC counts (stress, inflammation, parasitism), albumin (nutritional status), alanine aminotransferase (ALT; liver damage, infection, trauma, fasting status), and HGB (diving capability). Randomization tests, with 10,000 iterations, were used to test if there was a 
difference in the mean values of these four parameters for the same between-group comparisons (TW vs. RW seals and RA vs. all weanling seals).

In addition, aliquots of frozen serum were sent to diagnostic laboratories to test for antibodies to various infectious agents. The nasal and rectal swabs in VTM were used to test for influenza A (2008 and 2009) and B (2008 only). To determine the presence of enteric bacteria, fecal samples were cultured at UCD Veterinary Medical Teaching Hospital (Davis, CA). Along with reporting prevalence of infectious disease and enteric bacteria for each group, a contingency table was used to test the null hypothesis that there was no difference in the frequency of pathogen occurrence between resident and translocated monk seals. To ensure that $\leq 20 \%$ of category combinations had expected frequencies $<5.0$, only five infectious agent categories were included in the analysis: Chlamydophila abortus antibodies, Clostridium perfringens, Escherichia coli, Salmonella spp., and all other enteric bacteria detected in at least one seal were grouped ("other enteric"). The likelihood ratio was used to test statistical significance because it is less affected by small sample sizes. Post-hoc subdividing contingency tables were used to examine which pathogens likely were responsible for differences in infectious disease between resident and translocated seals.

\section{First-year survival analyses}

The first-year survival of TW seals was compared with two control groups: 1) non-translocated weanling seals that remained at FFS (FFS control, $\mathrm{n}=36$ ), and 2) weanling seals born at NIH (NIH control, $\mathrm{n}=16$ ) in 2008 and 2009. Re-sight efforts at NIH were limited to only five days in both 2009 and 2010 and two additional days in 
2011, whereas at FFS more than three months of daily surveys were conducted each year. The number of seals in each treatment group that were re-sighted at age one, or in subsequent years, relative to the total number of seals in each group was calculated as percentage first-year survival.

Because size at weaning affects first-year survival (Baker 2008), differences in body size among treatment groups were examined. As part of the long-term Hawaiian monk seal population monitoring efforts, all weanling seals were handled for morphometric measurements (AG and DSL) and flipper tagging as soon after weaning as possible (Johanos \& Baker 2011). Using weaning AG and DSL, a one-factor multivariate analysis of variance (MANOVA) was used to compare the body size of TW, FFS-control, and NIH-control seals. All data met the assumptions of univariate (UV) and multivariate (MV) normality and equal variance. No MV outliers were detected using Mahalanobis distances $(p \geq 0.027)$. One AG $(71 \mathrm{~cm})$ from a FFS-control seal was a UV outlier $(\mathrm{Z}$-score $=-2.66)$ but was retained in the analysis because this individual was measured within two weeks of weaning (Johanos \& Baker 2011). If the null hypothesis for the MANOVA was rejected, follow-up analyses were conducted to determine the relative importance of each response variable using analysis of variance (ANOVA) with a Bonferroni correction factor $(\alpha<0.025)$ and discriminant analysis.

To determine whether weanling seals translocated to NIH had greater probabilities of survival than non-translocated seals from the same cohorts, a logistic regression was used with survival to age one as the binary response variable (alive, presumed dead). At FFS, sex also affects juvenile survival (Baker \& Thompson 2007). 
Therefore, size and sex were included in the model as predictors along with treatment group (translocated, FFS control, and NIH control) to determine if these factors influenced first-year survival. Because AG and DSL were correlated $(r=0.833, p<$ 0.001), only girth was included in the logistic regression because it better predicts juvenile monk seal survival than length (Baker 2008). All test assumptions were met, and model selection was based on $\mathrm{AIC}_{\mathrm{C}}$.

Because the smallest weanling seals were unlikely to survive, they were not considered potential translocation candidates. To minimize this size-selection bias, separate MANOVA and logistic regression analyses were conducted including only weanling seals with AGs greater than the AG for the smallest seal to survive to age one.

\section{RESULTS}

Seven female and five male weanling seals were translocated to NIH at an average age of $78.2 \pm 5.0 \mathrm{~d}$ and $39.3 \pm 5.1 \mathrm{~d}$ post-weaning (Appendix 1). One TW seal (YA22) had a superficial ventral abdominal shark bite inflicted on 15 Jul 2009 that appeared to be completely healed at the time of translocation. The post-weaning acclimation period for TW seals was approximately three months $(83.9 \pm 4.9 \mathrm{~d})$, but the shortest acclimation period was $64 \mathrm{~d}$ (Appendix 8). Time from RW seal capture date to end of the post-weaning acclimation period was greater for RW seals $(63.6 \pm 9.3 \mathrm{~d})$ than TW seals $(34.1 \pm 3.6 \mathrm{~d})$.

Telemetry data were excluded from all analyses for four TW, three RW, and two RA seals with tracking durations that were significantly reduced $(\leq 26 \mathrm{~d})$ or did not 
extend beyond the post-weaning acclimation period (Appendix 9). These individuals had few dive records and rarely moved beyond NIH (Appendix 10). Despite the near-shore release of TW seals, transmissions ceased four days post-release for one TW seal (YW27) that never hauled out at NIH. The twenty seals included in the foraging behavior and habitat use analyses were tracked for $132.9 \pm 15.0 \mathrm{~d}$ (Appendix 11). Satellite tracking durations for RA seals $(98.1 \pm 25.1 \mathrm{~d})$ were less than weanling seals (TW: $162.6 \pm 21.6 \mathrm{~d}, \mathrm{RW}: 133.8 \pm 29.4 \mathrm{~d}$ ).

\section{Dive behavior}

Resident and translocated seals did not dive to depths $>300$ m (Appendix 12). Many TW and RW seals logged several exploratory dives that were deeper than the majority of their dives. The maximum dive depth bin used by many weanling seals, therefore, was greater than that used by some RA seals.

Individual dive depth was more variable among the four 6-h periods for three TW (38\%), three RW (60\%), and five RA (71\%) seals compared with other seals (Appendices 13-15). A consistent diel pattern in dive depth was not observed among individual seals, but some individuals demonstrated deeper dives during daytime (R5EE) and others had deeper dives at night (YW07, RW64).

Most weanling seals (85\%) primarily dove between 40 and $60 \mathrm{~m}$ depth, whereas dive depth patterns were more variable among RA seals (Appendix 16). Compared with other weanling seals, one TW seal (YA26) had a greater proportion of dives $>60 \mathrm{~m}$ and two TW seals (YA10, YA42) and RW seals (RA52, RA54) had a greater proportion of dives between 60 and $80 \mathrm{~m}$. Less than $20 \%$ of dives for each weanling seal were $<10 \mathrm{~m}$. 
In contrast, several RA seals logged a greater proportion of dives $<10 \mathrm{~m}(0.24-0.42$ of dives for R2BK, R2BU, R2BY). Two RA seals (R2BU, R5EG) most frequently dove to $60-80 \mathrm{~m}$, and $44 \%$ of all dives for one adult female seal (R5EE) were $>80 \mathrm{~m}$ with only 6\% between 140 and $250 \mathrm{~m}$. Only one RA seal (R5EM) dove most frequently to 40-60 $\mathrm{m}$, similar to weanling seals.

For most individuals, particularly weanling seals, the greatest proportion of timeat-depth (TAD) was spent $<10 \mathrm{~m}$ and 40 to $60 \mathrm{~m}$ depth (Appendices 17-20). Although TAD frequency histograms emphasized the amount of time spent $<10 \mathrm{~m}$, which included time spent at the surface and on-land during each 6-h period, the TAD patterns otherwise closely aligned with the dive depth patterns.

The TW and RW seal groups had similar dive depth and TAD frequency histograms (Figure 2a-b). An average $0.58 \pm 0.06$ of all dives for TW seals were $40-60 \mathrm{~m}$ compared with $0.51 \pm 0.09$ for RW seals. RA seal diving activity was more variable, but this group most frequently dove to depths $<10 \mathrm{~m}$ and between 40 and $80 \mathrm{~m}$. The proportion of dives greater than $80 \mathrm{~m}$ was $<0.02$ for the weanling seal groups and $0.07 \pm$ 0.06 for RA seals. For all three groups, the proportion of TAD $<10 \mathrm{~m}$ was similar $(\sim$ 0.45). Proportion of time spent between 40 and $60 \mathrm{~m}$ was more similar between weanling seals (TW: $0.36 \pm 0.04$, RW: $0.34 \pm 0.04)$ compared with RA seals $(0.20 \pm$ $0.05)$. 

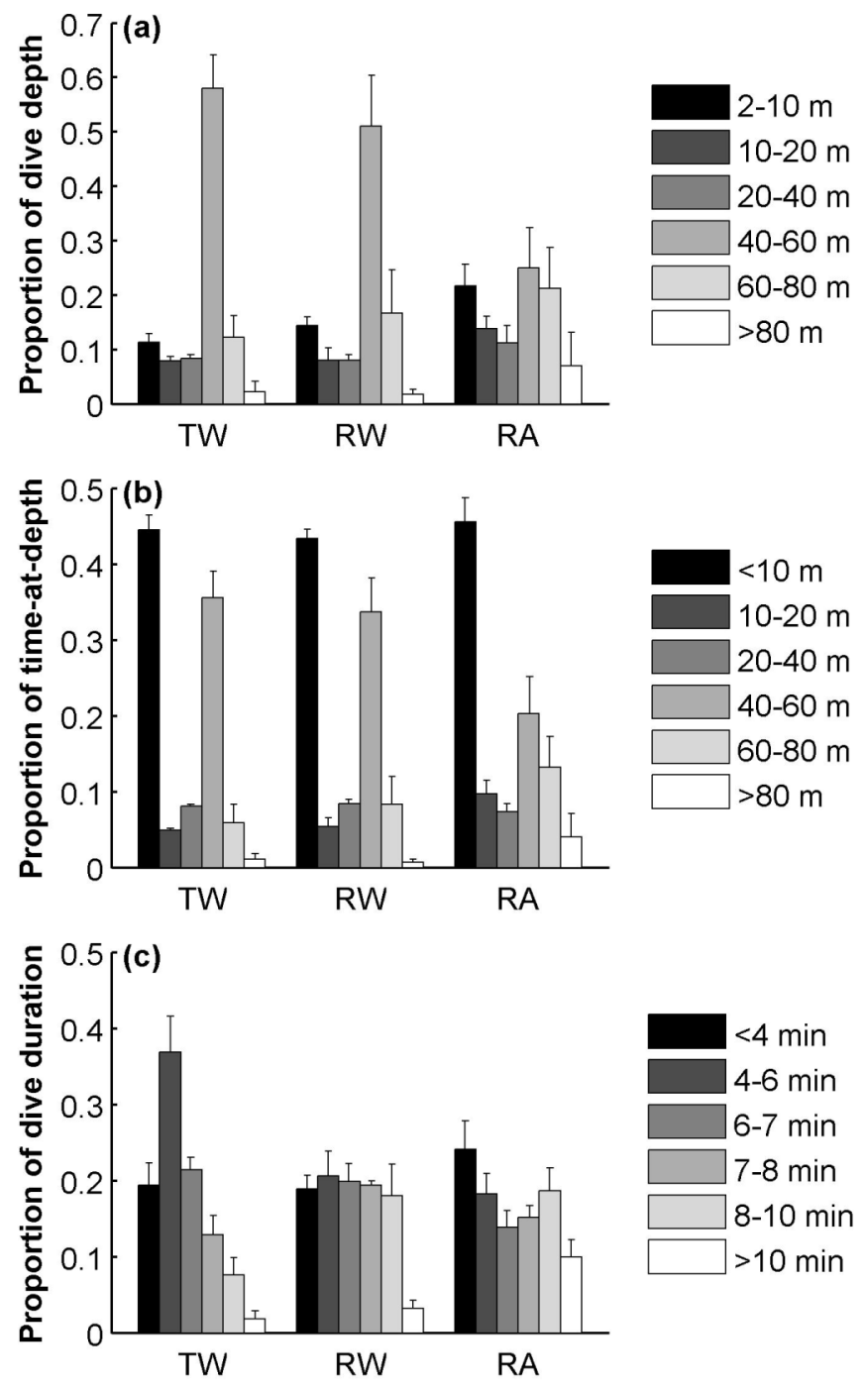

Figure 2. Group modal diving activity. Mean proportion of dives or time-at-depth to each depth (a-b) and duration (c) bin for translocated weanling (TW, $\mathrm{n}=8)$, resident weanling $(\mathrm{RW}, \mathrm{n}=5)$, and resident adult $(\mathrm{RA}, \mathrm{n}=7)$ monk seals. Error bars indicate SE.

Dive duration frequency histograms were consistent across the four 6-h periods for six TW (75\%) seals, but were more variable for RW and RA seals (Appendices 2123). Among individuals, however, there was no reliable pattern in the proportion of dives to each duration bin across the 6-h periods. Additionally, only one RW seal (RW64) 
demonstrated strong diel differences in the proportion of dives to each duration bin, with greater dive duration during nighttime (Appendix 22).

Among individuals, dive duration patterns were more variable for TW seals compared with RW and RA seals (Appendix 24). Five TW seals (YA20, YW19, YW07, YW24, YA42) had a greater proportion of dives that were 4-6 min with one of these individuals (YW19) also having a greater proportion of dives $<4$ min. Dives for the other three TW seals and four RW seals were similarly distributed among the five duration bins $<10 \mathrm{~min}$. One RW seal (RW64), however, dove most frequently for $<4$ min and 8-10 min. Two RA seals (R2BY, R2BU) were the only seals that dove $<4$ min most frequently. The other five RA seals had a similar proportion of dives to the six duration bins. Similar to weanling seals, dives $>10$ min were infrequent for two RA seals (R2BU, R5EG).

The dive duration frequency histograms were more similar between RW and RA seals, whereas TW seals more frequently dove for shorter durations with an average 0.37 \pm 0.05 of their dives between four and six min (Figure 2c). Although individual seals in each group dove for durations in excess of $25 \mathrm{~min}$ (Appendix 12), more than $90 \%$ of all dives for each group were $<10 \mathrm{~min}$.

\section{Horizontal spatial use}

Few Fast-GPS locations $(\leq 2.3 \%)$ were removed with filtering, however, the mean transmission interval between consecutive GPS locations was variable among seals (range $=2-8 \mathrm{~h}$; Appendix 11). For each individual, areas with the greatest density of filtered Fast-GPS locations corresponded to the areas of greatest use represented by the 
UDs created using interpolated locations (Appendices 25-31). The 50\% or $60 \%$ UD isopleth was defined as the dividing point between the HR core and peripheral areas for all individuals (Appendices 32-35). As expected, individual HRs excluded occasional forays; areas that were rarely used by each individual, which for weanling seals often included the most distant locations from NIH; and transit corridors between seamounts where seals spent little residence time.

Almost all of the movements of translocated and resident weanling seals occurred around NIH in water depths $<200 \mathrm{~m}$ (Appendices 25-26). Only three TW seals (YA26, YW19, YW24) briefly visited the terrace to the west of NIH (WNB terrace), and no RW seals used this nearby bank. The most intensely used area for many TW (YW24, YA20, YW19, YA10, YA42) and RW (RA54, RW68) seals was 8-13 km to the east of NIH (Appendices 29-30). Two weanling seals (YW07, RW64) spent a greater amount of time closer to but also east of NIH, whereas one TW seal (YA08) used an expanded area to the east of NIH most intensely. For the remaining weanling seals, the areas of greatest use were: to the west of NIH (YA26), within $4 \mathrm{~km}$ of NIH (RA52), and near the eastern to southern edge of the flat terrace habitat around NIH (RW62). Thus, there was substantial core and HR area overlap among weanling seals.

Similar to weanling seals, RA seals spent the majority of their time over the flat terrace habitat ( $<200 \mathrm{~m}$; Appendices 27, 31). The movements of the RA seals were concentrated further around the $60-\mathrm{m}$ depth contour. In contrast to weanling seals, however, significant spatial segregation was observed among RA seals. Five RA seals exclusively used the NIH and WNB terrace habitat, and two of these seals (R5EM, 
R2BY) primarily used the WNB. One adult male seal (R2BU) used an unnamed bank 90 $\mathrm{km}$ southeast of NIH. In addition, an adult female seal (R5EE) primarily used the shallow-water habitat at Twin Banks, > 100 km northwest of NIH, and also briefly traveled over deep water west of NIH. Two RA seals (R2BK, R5EM) with the shortest tracking durations (Appendix 11) had the most restricted HR areas. There was less overlap among HR and core areas for RA seals due to their increased spatial segregation.

The three groups of seals had similar individual core and HR areas despite the RA seals' use of more distant foraging areas because most RA seals visited the same areas repeatedly (Table 1, Appendix 35). Although RW seals had more restricted HRs than TW seals, this difference was not significant $\left(t_{11}=0.676, p=0.513, r=0.200\right)$. The HR areas of RA seals were slightly greater, but not significantly different $\left(t_{18}=-0.535, p=\right.$ $0.599, r=0.125)$, than those of weanling seals. There also were no differences in core area size between TW and RW seals $\left(t_{11}=0.755, p=0.466, r=0.222\right)$ or weanling and RA seals $\left(t_{18}=0.132, p=0.897, r=0.031\right)$. Core areas comprised a greater proportion of the HR areas for weanling seals compared with RA seals. 
Table 1. Group home range (HR) and core area summary statistics. Means \pm SEs were calculated for translocated weanling (TW), resident weanling (RW), resident adult (RA), all weanling (W), and all seals (All). The values representing the combined horizontal spatial use of each group are in parentheses. To separate the HR core and peripheral areas, the dividing point was rounded down to the nearest $10 \%$ utilization distribution (UD) isopleth. Core area was divided by HR area to calculate percent core area.

\begin{tabular}{lrccrcr}
\hline & $\mathrm{n}$ & $\begin{array}{c}\text { Dividing point } \\
(\% \mathrm{UD})\end{array}$ & Core area $\left(\mathrm{km}^{2}\right)$ & HR area $\left(\mathrm{km}^{2}\right)$ & Percent core area \\
\hline TW & 8 & $61.5 \pm 0.8(68.8)$ & $42.5 \pm 6.9(74)$ & $176.3 \pm 22.4$ & $(548)$ & $24.2 \pm 2.2(13.5)$ \\
RW & 5 & $59.8 \pm 1.5(63.8)$ & $34.4 \pm 7.9(60)$ & $149.2 \pm 36.1$ & $(322)$ & $23.2 \pm 1.6(18.6)$ \\
RA & 7 & $60.1 \pm 1.2(63.0)$ & $38.3 \pm 6.2(158)$ & $185.7 \pm 36.7$ & $(880)$ & $21.5 \pm 1.3(18.0)$ \\
W & 13 & $60.8 \pm 0.8(69.7)$ & $39.4 \pm 5.1(74)$ & $165.8 \pm 19.0$ & $(594)$ & $23.8 \pm 1.5(12.5)$ \\
All & 20 & $60.6 \pm 0.6(68.8)$ & $39.0 \pm 3.9(116)$ & $172.8 \pm 17.4(1096)$ & $23.0 \pm 1.1(10.6)$ \\
\hline
\end{tabular}

All group HRs were divided into core and peripheral areas at the $60 \%$ UD isopleth (Table 1, Appendix 36). The area immediately around NIH and $<13 \mathrm{~km}$ east of $\mathrm{NIH}$ were used to a greater degree by the weanling seal groups (Figure 3). Thus, there was substantial overlap between the core and HR areas of TW and RW seals (Table 2). RA seals rarely used the interior region of the NIH terrace that was primarily used by TW and RW seals, and consequently this area was largely excluded from their HR (Figure 3). Instead, RA seals predominately used the edges of the terraces, often in the southeastern or northwestern direction relative to the terrace center. As a result, core and HR areas for weanling and RA seals overlapped to a lesser extent (Table 2). In addition, HR area for all seals combined included almost all of the shallow-water terrace habitat available around NIH and at the four nearby banks (Figure 3). Core habitat for all seals also covered approximately half of the NIH terrace within $13 \mathrm{~km}$ of the island. 

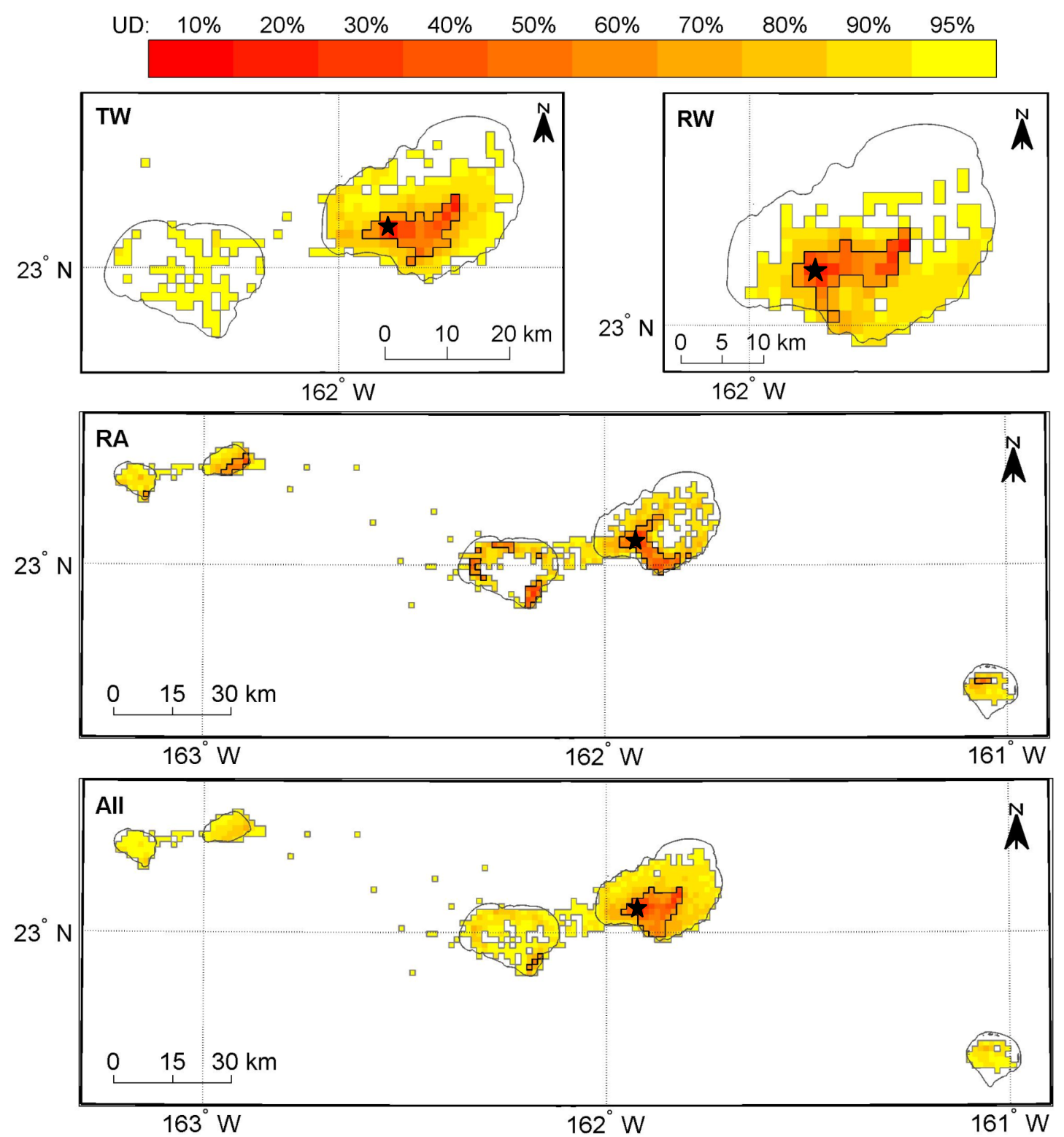

Figure 3. Group utilization distributions (UDs). Home ranges are the total colored area and core areas are outlined in black for translocated weanling (TW), resident weanling (RW), resident adult (RA), and all monk seals. Red indicates areas of greatest use, and yellow represents less intensely used areas. The grid cells are $2 \mathrm{~km}^{2}$, the black star marks the location of NIH, and the $200-\mathrm{m}$ isobath is indicated by the gray line. 
Table 2. Core and home range (HR) area overlap between groups of seals. TW= translocated weanlings, $\mathrm{RW}=$ resident weanlings, $\mathrm{RA}=$ resident adults, and $\mathrm{W}=$ all weanlings.

\begin{tabular}{lccllc}
\hline & \multicolumn{2}{c}{ Core overlap } & & \multicolumn{2}{c}{ HR overlap } \\
\cline { 2 - 3 } \cline { 6 - 6 } & $\mathrm{km}^{2}$ & $\%$ & & $\mathrm{~km}^{2}$ & $\%$ \\
\hline TW vs. RW & 48 & 55.8 & & 276 & 46.5 \\
RW vs. RA & 26 & 13.5 & & 246 & 25.7 \\
TW vs. RA & 38 & 19.6 & & 348 & 32.2 \\
W vs. RA & 38 & 19.6 & & 378 & 34.5 \\
\hline
\end{tabular}

\section{Foraging trips}

There were similar foraging trip distances, RSIs, durations, and directions among individual weanling seals (Appendix 37). TW seals that briefly visited the WNB terrace (YA26, YW19, YW24) did not have greater mean trip distances or durations than other weanling seals. Mean maximum trip distances were slightly greater for TW seals $(10.4 \pm$ $0.5 \mathrm{~km})$ compared with RW seals $(9.4 \pm 1.0 \mathrm{~km})$ as were mean total trip distances (TW: $40.6 \pm 3.9 \mathrm{~km}, \mathrm{RW}: 35.5 \pm 3.5 \mathrm{~km}$ ) and trip durations (TW: $3.1 \pm 0.3 \mathrm{~d}, \mathrm{RW}: 2.6 \pm 0.3 \mathrm{~d}$; Figure 4). In contrast, RSIs for RW seals were slightly greater $(3.6 \pm 0.4)$ than the TW seals' RSIs $(3.5 \pm 0.2)$. There were no differences, however, in mean maximum trip distance $\left(t_{11}=1.039, p=0.321, r=0.299\right)$ or RSI $\left(t_{11}=-0.245, p=0.811, r=0.074\right)$ between TW and RW seals. 

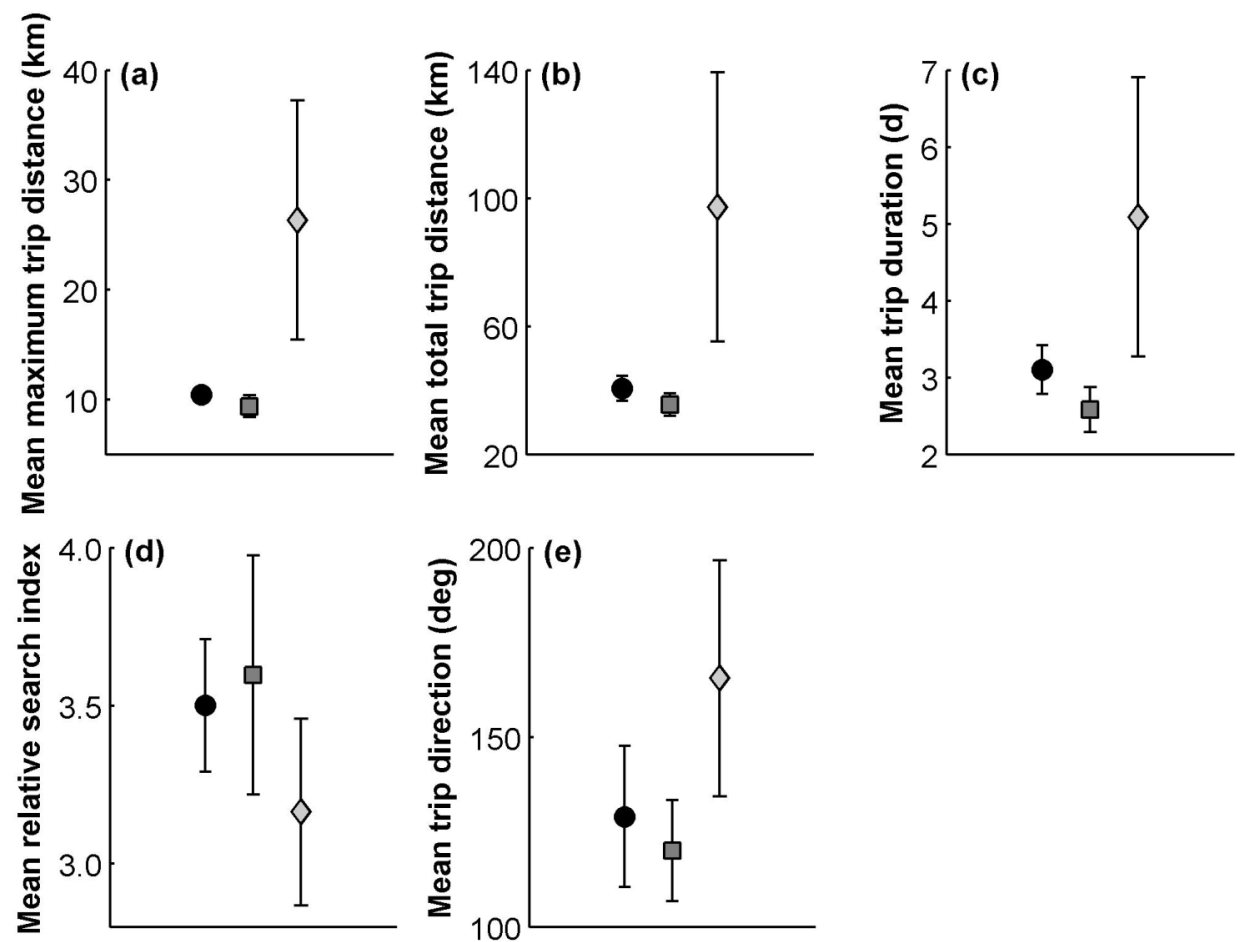

Figure 4. Group foraging trip statistics. Means were calculated for (a) maximum trip distance, (b) total trip distance, (c) trip duration, (d) relative search index, and (e) trip direction for translocated weanling $(\bullet)$, resident weanling $(\square)$, and resident adult $(\diamond)$ seals. Error bars represent SE.

Among RA seals, there was greater variability in foraging trips (Appendix 37).

Mean trip distances and duration for one adult male seal (R5EI) were considerably less than all other seals. In contrast, the adult female seal (R5EE) that made ten foraging trips to Twin Banks during eight months (Appendix 11) had significantly greater trip distances and durations. Although there was significant individual variability among RA seals, as expected, they had greater mean maximum $(26.3 \pm 10.9 \mathrm{~km})$ and total $(97.3 \pm 42.0 \mathrm{~km})$ trip distances and durations $(5.1 \pm 1.8 \mathrm{~d})$ than weanling seals (Figure 4). Variance for maximum trip distance was significantly greater for RA seals than weanling seals $\left(F_{6,12}=\right.$ 263.811, $p<0.001)$. Therefore, a randomization test was performed, and a significant 
difference in maximum trip distance was detected between weanling and RA seals $(p<$ $0.05)$. Weanling seals had slightly greater mean RSIs than RA seals ( $3.2 \pm 0.3)$, however this result was not statistically significant $\left(t_{18}=1.128, p=0.274, r=0.257\right)$.

Generally trip directions were to the southeast for TW $\left(129.1 \pm 18.6^{\circ}\right)$ and RW $\left(120.1 \pm 13.3^{\circ}\right)$ seals and more southerly for RA seals $\left(165.6 \pm 31.2^{\circ}\right)$, although there was greater variability among RA seals (range $=65-269^{\circ}$; Figure $4 \mathrm{e}$, Appendix 37 ). Mean trip direction was not significantly different between TW and RW seals $\left(t_{11}=0.346, p=\right.$ $0.736, r=0.104)$ or weanling and RA seals $\left(t_{18}=-1.426, p=0.171, r=0.319\right)$.

\section{Foraging habitat use}

Eleven habitat assessment sites primarily had mobile unconsolidated (UN) sediment (Figure 5, Appendices 38-39). These sites had either sandy bottoms with large regular and parallel ripples indicative of deep sand or shallower sand, indicated by small, flat, or irregular ripples, with scattered rocky outcrops or rubble. The UN sites were concentrated $<12 \mathrm{~km}$ to the east of NIH. Three sites on the WNB terrace also had UN sediment. All UN sites had no to little surface roughness or macroalgal cover. Only one UN site had a few small isolated cauliflower coral colonies, likely Pocillopora ligulata or P. meandrina, on a large rocky ledge. Additionally, five UN sites to the east of NIH had sand-colored oval organisms densely covering the peaks of the large, regular sand ripples, likely aggregations of spawning adult heart urchins (B. latecarinatus). 


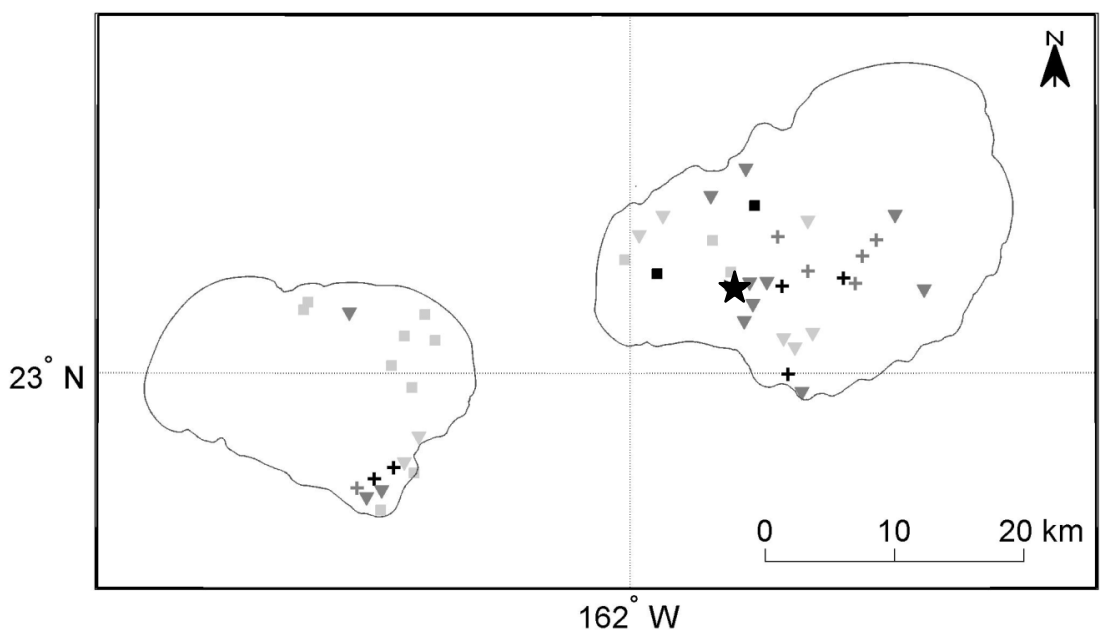

Figure 5. Surface texture classifications for camera drop sites. Hard-bottom (HB) with high ( $($ ) or colonized HB with moderate $(\bullet)$ roughness (substrate type 1). Uncolonized HB with moderate $(\nabla)$ or low $(\nabla)$ roughness (substrate type 2$)$. Unconsolidated sediment with low $(+)$ or no $(+)$ roughness (substrate type 3 ). The black star marks the location of $\mathrm{NIH}$, and the $200-\mathrm{m}$ isobath is indicated by the gray line.

Greater than $75 \%$ of the sites surveyed were predominantly hard-bottomed (HB;

Figure 5, Appendices 38-39). Pavement (low-relief, solid carbonate rock) was the dominant HB type with exposed basalt rock at most near-shore sites. Three HB sites (\# 8-10) along the northwest edge of the NIH terrace had alternating pavement and sand channels perpendicular to shore. Many HB sites on the WNB had high surface roughness (53\%), whereas only $11 \%$ of HB sites on the NIH terrace had high roughness. Coral and macroalgae were present at all HB sites in which these two biological cover modifiers were identifiable with the exception of one site that had more sandy areas. It was difficult to determine if rocky features at some sites were attached outcrops or loose rocks and dead coral fragments, but there may have been talus on the southeastern corner of the WNB terrace. In addition, large features were present at six sites. 
A variety of algal, invertebrate, and fish species were present at the camera drop sites. Turf algae were present at most HB sites as was Microdictyon algae, and several sites had large Codium plants. Camera kiting made it difficult to identify some biological components of the benthic habitat that may have been present, such as crustose coralline algae. In addition, isolated cauliflower coral colonies and lobe corals, such as Porites lobata and P. evermanni, were commonly observed at HB sites. Other hard corals, including Acropora sp., Montipora sp., and Porites compressa, were less common or rare. Reef fishes were present in groups of less than five at many sites but schools with $>$ 30 smaller fishes also were observed at several sites. For all drifts, the total distance surveyed was $\sim 4 \mathrm{~km}$, and over this distance one marine eel, shark, and adult-sized flounder were observed. The deepest camera drop site (\# 37), located on the southeastern edge of the WNB terrace, was the only site with vertical relief (a steep wall with numerous ledges, overhangs, caves, and crevices) and had the greatest density and diversity of macroalgae, fish, and invertebrates.

The more static geomorphologic characterizations of the benthic habitat were used to assess which factors influenced foraging habitat use for each group of seals. For TW seals, surface roughness was a better predictor of habitat use on the NIH terrace than induration or substrate type (Table 3). Relative to areas with low, moderate, and high roughness, TW seals primarily used areas with no surface roughness (Table 4, Figure 6a). Five of the sites with no surface roughness that TW seals targeted had deep sand and dense aggregations of heart urchins. Distance and direction to NIH also were significant predictors of TW seal habitat use (Tables 3-4). TW seals demonstrated greater use of 
four sites $<4 \mathrm{~km}$ and six sites $7-12 \mathrm{~km}$ from NIH (Figure 6b). One site that was $11.6 \mathrm{~km}$ from NIH was used more than twice as much by TW seals than any other site. Excluding this site from the TW seal habitat use model, however, did not change the results.

Table 3. Generalized linear models that best predicted foraging habitat use of each group of seals for the three surface texture variables. Models with the greatest log likelihood (LL) value did not always correspond to the model with the least $\mathrm{AIC}_{\mathrm{C}}$, which represents a greater penalty for more variables or factor levels. $\mathrm{AIC}_{\mathrm{C}}=[2 k-2(\mathrm{LL})]+[2 k(k+1) / n$ $-k-1]$, where $k=$ number of parameters and $n=$ sample size. The change in $\operatorname{AIC}_{\mathrm{C}}(\Delta$ $\mathrm{AIC}_{\mathrm{C}}$ ) is relative to the best fitting model for each group. The null model includes only the intercept term and $d f=$ degrees of freedom.

\begin{tabular}{|c|c|c|c|c|}
\hline & LL & $\mathrm{AIC}_{\mathrm{C}}$ & $\Delta \mathrm{AIC}_{\mathrm{C}}$ & $d f$ \\
\hline \multicolumn{5}{|l|}{ Translocated weanlings $\dagger$} \\
\hline Roughness + direction + distance + distance $^{2}$ & 128.891 & -234.203 & & 21 \\
\hline Induration + direction + depth & 121.234 & -229.741 & 4.462 & 24 \\
\hline Substrate + direction + depth & 121.573 & -227.145 & 7.058 & 23 \\
\hline Null model & 107.731 & -210.982 & 23.221 & 27 \\
\hline \multicolumn{5}{|l|}{ Resident weanlings $\dagger$} \\
\hline Induration + direction + depth + depth $^{2}$ & 101.284 & -186.567 & & 23 \\
\hline Substrate + direction + depth + depth $^{2}$ & 101.503 & -183.407 & 3.160 & 22 \\
\hline Roughness + direction + depth + depth $^{2}$ & 98.281 & -172.983 & 13.584 & 21 \\
\hline Null model & 80.595 & -156.709 & 29.858 & 27 \\
\hline \multicolumn{5}{|l|}{ Resident adults } \\
\hline Roughness + features + distance + distance $^{2}$ & 185.277 & -350.554 & & 38 \\
\hline Substrate + features + distance + distance $^{2}$ & 179.059 & -341.092 & 9.462 & 39 \\
\hline Features + distance + distance $^{2}$ & 171.330 & -331.122 & 19.432 & 41 \\
\hline Induration + features + depth $^{2}+$ distance + distance $^{2}$ & 172.332 & -327.637 & 22.917 & 39 \\
\hline Null model & 158.804 & -313.322 & 37.232 & 44 \\
\hline \multicolumn{5}{|l|}{ All seals $\$$} \\
\hline Substrate + distance + distance $^{2}$ & 219.208 & -424.206 & & 40 \\
\hline Roughness + features + distance + distance $^{2}$ & 219.442 & -418.885 & 5.321 & 38 \\
\hline+ features + direction + depth & 216.142 & -418.073 & 6.133 & 40 \\
\hline Null model & 196.151 & -388.017 & 36.189 & 44 \\
\hline
\end{tabular}

$\dagger$ NIH-only models: run using 28 sites on NIH terrace \$ All-sites models: run using all 45 sites 
Table 4. Generalized linear model coefficients $(B)$ for each group's best fitting habitat use model. $\mathrm{SE}=$ coefficient standard error; $\mathrm{HB}-\mathrm{col} / \mathrm{H}=$ hard-bottom $(\mathrm{HB})$, colonized or high roughness; and $\mathrm{HB}$ - uncol/L-M = uncolonized HB, low-moderate roughness.

\begin{tabular}{|c|c|c|c|c|}
\hline & $B$ & $\overline{\mathrm{SE}}$ & $x^{2}$ & $p$ \\
\hline \multicolumn{5}{|c|}{ Translocated weanlings } \\
\hline Intercept & -1.864 & 1.304 & & \\
\hline \multicolumn{3}{|c|}{ Roughness (relative to none) } & 30.701 & $<0.001$ \\
\hline low & -1.074 & 0.360 & & \\
\hline moderate & -2.881 & 0.468 & & \\
\hline high & -3.330 & 0.846 & & \\
\hline Direction & 0.006 & 0.003 & 4.473 & 0.034 \\
\hline Distance & -1.022 & 0.221 & 18.612 & $<0.001$ \\
\hline Distance $^{2}$ & 0.060 & 0.014 & 15.339 & $<0.001$ \\
\hline \multicolumn{5}{|c|}{ Resident weanlings } \\
\hline Intercept & 7.358 & 3.882 & & \\
\hline \multicolumn{3}{|c|}{ Induration (relative to HB) } & 32.895 & $<0.001$ \\
\hline unconsolidated & 2.561 & 0.374 & & \\
\hline Direction & 0.008 & 0.003 & 8.309 & 0.004 \\
\hline Depth & -0.572 & 0.171 & 9.634 & 0.002 \\
\hline Depth $^{2}$ & 0.005 & 0.002 & 6.718 & 0.010 \\
\hline \multicolumn{5}{|l|}{ Resident adults } \\
\hline Intercept & -6.680 & 0.700 & & \\
\hline \multicolumn{3}{|c|}{ Roughness (relative to none) } & 27.893 & $<0.001$ \\
\hline low & 2.192 & 0.617 & & \\
\hline moderate & 1.552 & 0.621 & & \\
\hline high & 0.270 & 0.675 & & \\
\hline \multicolumn{3}{|c|}{ Features (relative to absent) } & 10.760 & 0.001 \\
\hline present & 1.264 & 0.375 & & \\
\hline Distance & -0.304 & 0.080 & 13.434 & $<0.001$ \\
\hline Distance $^{2}$ & 0.010 & 0.002 & 17.600 & $<0.001$ \\
\hline \multicolumn{5}{|l|}{ All seals } \\
\hline Intercept & -5.408 & 0.393 & & \\
\hline \multicolumn{3}{|c|}{ Substrate (relative to HB - col/H) } & 29.123 & $<0.001$ \\
\hline HB - uncol/L-M & 1.065 & 0.337 & & \\
\hline unconsolic & 2.064 & 0.361 & & \\
\hline Distan & -0.241 & 0.058 & 16.005 & $<0.001$ \\
\hline Distance $^{2}$ & 0.006 & 0.002 & 11.442 & 0.001 \\
\hline
\end{tabular}



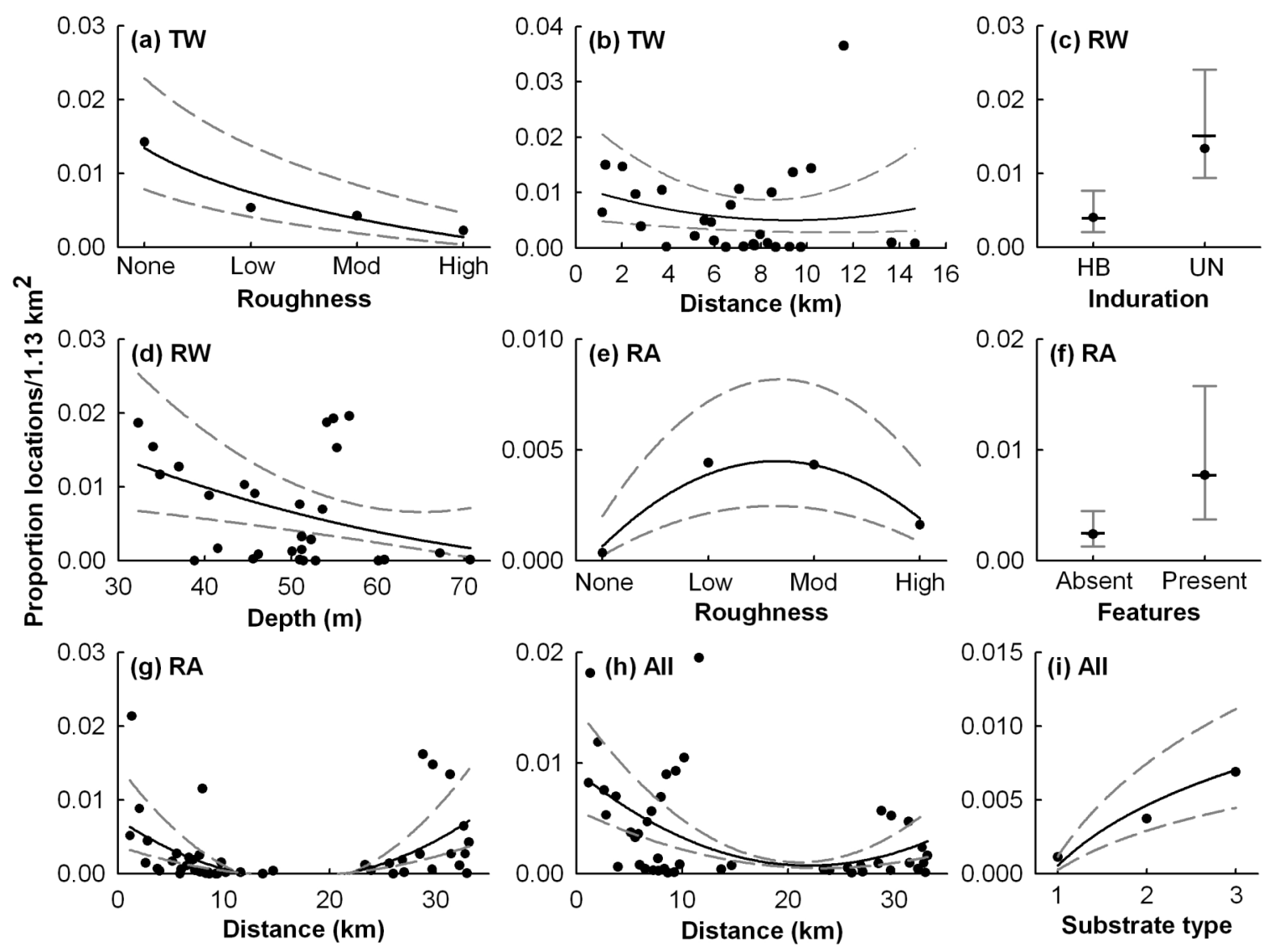

Figure 6. Relationship between each term in the best fitting habitat use models and proportion of locations per area of influence. Observed means or values $(\bullet)$ and generalized linear model predicted means $(-)$ and $95 \%$ confidence intervals $(--)$ for translocated weanling (TW), resident weanling (RW), resident adult (RA), and all seals (All). Substrate type $1=$ hard-bottom (HB), colonized or high roughness; type $2=$ uncolonized $\mathrm{HB}$, low-moderate (mod) roughness; and type 3 = unconsolidated (UN) sediment.

In contrast, the best fit benthic habitat use model for RW seals included induration, direction, and depth as significant predictor variables ( $p \leq 0.010$; Tables $3-4)$. For RW seals, the top model for each surface texture variable included direction to NIH and a quadratic depth term (Table 3). These models were only slightly better than comparable models with distance to $\mathrm{NIH}$, and its squared term, substituted for depth and 
$\operatorname{depth}^{2}$ (e.g., induration + direction + distance + distance ${ }^{2}$ model $\mathrm{AIC}_{\mathrm{C}}=-186.475, \Delta$ $\mathrm{AIC}_{\mathrm{C}}=0.092$ ). This group of weanling seals used areas with UN sediment more intensely than HB sites (Table 4, Figure 6c). RW seals also demonstrated greater use of shallower sites that were closer to NIH and four UN sites that were $\sim 55 \mathrm{~m}$ deep but rarely used areas $>60 \mathrm{~m}$ (Figure 6d). The same relationship between habitat use and depth also was observed for TW seals although distance to NIH rather than depth was included in the best fitting model for this group. In addition, there was a similar relationship between direction to NIH and habitat use for the two groups of weanling seals (Table 4). In agreement with the foraging trip direction statistics, TW and RW seals used sites to the east and southeast of NIH most intensely.

Similar to TW seals, roughness better predicted benthic habitat use for RA seals than substrate type or induration (Table 3). RA seals demonstrated reduced use of sites having no and high surface roughness and used areas with moderate and especially those with low roughness more intensely (Table 4, Figure 6e). In addition, the presence of large features was an important predictor of RA seal habitat use (Table 3). RA seals used areas with large features present more than those without features (Table 4, Figure 6f).

There was a significant quadratic relationship between habitat use and distance to NIH for RA seals and all seals combined (Tables 3-4). RA seals primarily used the closest NIH sites and most distant WNB sites (Figure 6g). For all seals combined, sites close to NIH ( $<4 \mathrm{~km}$ away) were used most intensely, as were six sites $7-12 \mathrm{~km}$ from $\mathrm{NIH}$ and the most distant WNB sites (Figure 6h). The seals' greatly reduced use of the deep-water $(\sim 350 \mathrm{~m})$ transit corridor between the shallow NIH and WNB terraces, and 
lack of sampling within this corridor, also contributed to the non-linear relationship between habitat use and distance to NIH for these two groups. Although distance to NIH rather than depth was included in the best-fit models for these two groups, RA seals and all seals combined used shallower sites to a greater extent than deeper sites (Appendix 40). Similar to TW and RW seals, there was an increase in habitat use at $\sim 55 \mathrm{~m}$ for all seals combined. RA seals, however, demonstrated greater use of four sites between 50 and $54 \mathrm{~m}$ and rarely used sites $>54 \mathrm{~m}$.

Additionally, for all seals combined, substrate type was a better predictor of habitat use than roughness or induration (Table 3). Monk seals primarily used UN substrate at the NIH and WNB terraces (Table 4, Figure 6i). Uncolonized HB sites with low to moderate roughness were used to a lesser extent, but HB sites with $>10 \%$ coral cover or high surface roughness were used the least by resident and translocated seals.

\section{Health status}

All hematology variable ranges overlapped for TW, RW, and RA seals (Figure 7a-b, Appendices 41-42). TW and RW seals had similar WBC $(p>0.14)$ and HGB $(p>$ $0.05)$ concentrations, but RA seals had greater WBC $(p<0.01)$ and HGB $(p<0.05)$ than weanling seals. RA seals also had greater eosinophils and decreased lymphocytes compared with TW and RW seals. All WBC and HGB concentrations were within the ranges published for adult or weanling Hawaiian monk seals, as were most values for the other hematology variables. 

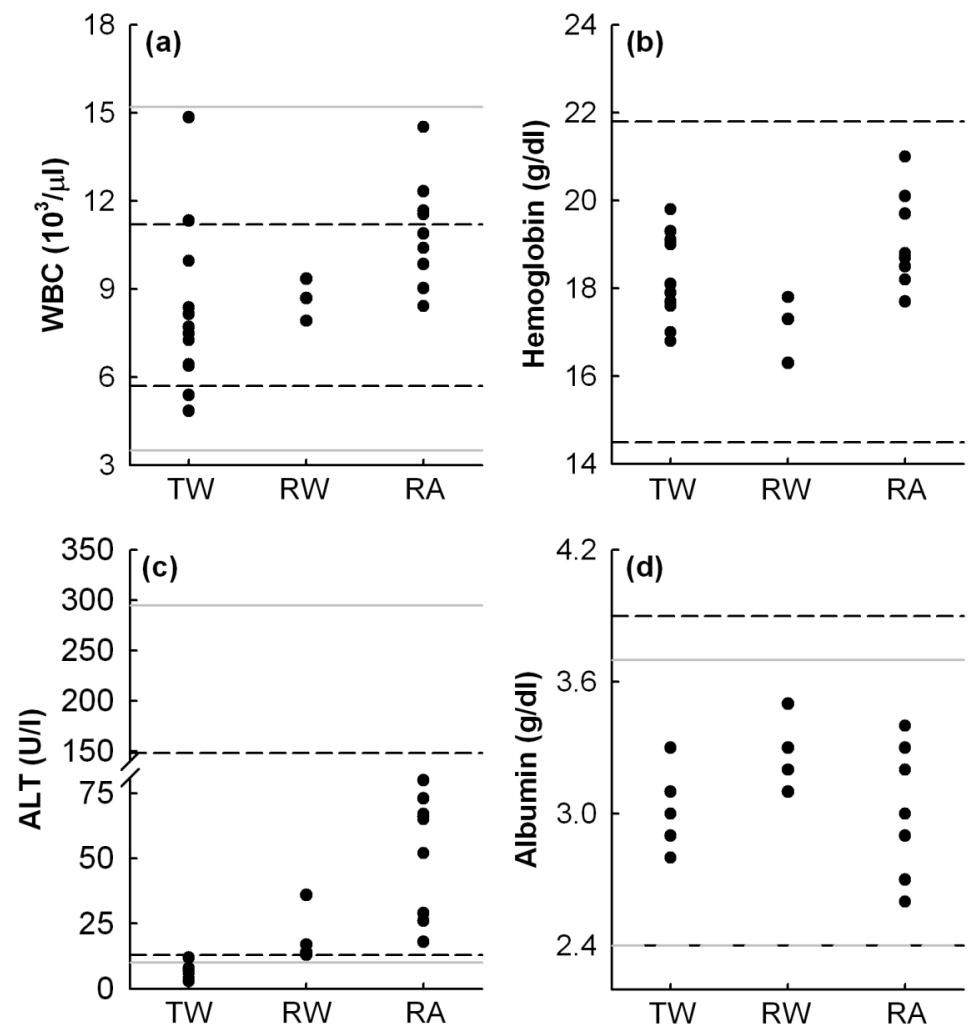

Figure 7. Values for blood parameters selected as broad indicators of health. Published reference ranges for weanling (Banish \& Gilmartin 1988; - - -) and non-weanling (Reif et al. 2004; - ) Hawaiian monk seals. TW = translocated weanlings, RW = resident weanlings, $\mathrm{RA}=$ resident adults, $\mathrm{WBC}=$ white blood cells, and $\mathrm{ALT}=$ alanine aminotransferase.

There was less overlap in serum chemistry values among the three groups, and for several variables (ALT and cholesterol) ranges were non-overlapping for one group (Figure 7c-d, Appendices 43-44). ALT values for TW seals were significantly less than those of RW seals $(p<0.003)$. Greater ALT values were observed in RA seals relative to weanling seals $(p<0.001)$. RW seals also had greater albumin levels compared with TW seals $(p<0.02)$, but there was no difference in albumin between weanling and RA seals $(p>0.16)$. Serum chemistry values typically were within the published ranges for monk 
seals, although most ALT values for TW seals were less than the published ranges for weanling and adult monk seals. Many blood urea nitrogen (BUN), potassium, and sodium values for TW and RW seals also were less than the published lower limits for weanling monk seals, and cholesterol levels for five TW seals exceeded the monk seal weanling reference range.

Resident and translocated seals were negative for influenza A and B and exposure to Brucella spp.; canine adeno-, parvo-, and distemper viruses; cetacean morbillivirus; Dirofilaria immitis; feline calicivirus; phocine distemper virus and herpesvirus-1; and Toxoplasma gondii (Table 5). All seals also had negative antibody titers for Leptospira spp., except for one adult male seal (R5EI) that had a positive titer (1:100) for $L$. borgpetersenii serovar Ballum. In addition, Chlamydophila abortus antibodies were detected in $42 \%$ of translocated and $77 \%$ of resident monk seals. 
Table 5. Prevalence of infectious agents or antibodies to them. TW $=$ translocated weanlings, $\mathrm{RW}=$ resident weanlings, and $\mathrm{RA}=$ resident adults.

\begin{tabular}{lccccc}
\hline & TW & RW & RA & $\begin{array}{c}\text { Test } \dagger \\
\text { (titer threshold) }\end{array}$ & Lab $\ddagger$ \\
\hline $\begin{array}{l}\text { Chlamydophila abortus } \\
\text { Leptospira borgpetersenii }\end{array}$ & $5 / 12$ & $2 / 4 \|$ & $8 / 9 \dagger \dagger$ & CF $(<1: 10)$ & NVSL \\
$\quad$ serovar Ballum & $0 / 12$ & $0 / 4$ & $1 / 9$ & MAT $(<1: 100)$ & NVSL \\
Brucella spp. & $0 / 12$ & $0 / 4$ & $0 / 9$ & ELISA, FPA & CFIA \\
Canine adenovirus & $0 / 11$ & $0 / 4$ & $0 / 9$ & VN $(<1: 4)$ & WADDL \\
Canine distemper virus & $0 / 12$ & $0 / 4$ & $0 / 9$ & VN $(<1: 8)$ & ADL \\
Canine parvovirus & $0 / 5$ & $0 / 4$ & $0 / 9$ & IFA-IgG $(<1: 25)$ & WADDL \\
Cetacean morbillivirus & $0 / 12$ & $0 / 4$ & $0 / 9$ & VN $(<1: 8)$ & ADL \\
Dirofilaria immitis & $0 / 12$ & $0 / 4$ & $0 / 9$ & Ag & IDEXX \\
Feline calicivirus & $0 / 11$ & $0 / 4$ & $0 / 9$ & VN $(<1: 4)$ & WADDL \\
Influenza A & $0 / 12$ & $0 / 4$ & $0 / 9$ & RT-PCR, VI, Ag & NWHC \\
Influenza B & $0 / 6$ & -- & $0 / 4$ & Ag & NWHC \\
Leptospira spp. $\S$ & $0 / 12$ & $0 / 4$ & $0 / 9$ & MAT $(<1: 100)$ & NVSL \\
Phocine distemper virus & $0 / 12$ & $0 / 4$ & $0 / 9$ & VN $(<1: 8)$ & ADL \\
Phocine herpesvirus-1 & $0 / 12$ & $0 / 4$ & $0 / 9$ & VN $(<1: 8)$ & ADL \\
Toxoplasma gondii & $0 / 12$ & $0 / 4$ & $0 / 9$ & MAT $(<25)$ & USDA \\
\hline
\end{tabular}

$\uparrow \mathrm{CF}=$ complement fixation, MAT = microscopic agglutination test, ELISA = enzymelinked immunosorbent assay, FPA = fluorescence polarization assay, $\mathrm{VN}=$ viral neutralization, IFA-IgG = immunofluorescence assay-serum immunoglobulin, Ag = antigen test, $\mathrm{RT}$-PCR = reverse-transcription polymerase chain reaction, $\mathrm{VI}=$ viral isolation

+ NVSL $=$ National Veterinary Service Laboratories, Ames, IO; CFIA = Canadian Food Inspection Agency, Ottawa, Canada; WADDL = Washington Animal Disease Diagnostic Lab, Pullman, WA; ADL = Athens Diagnostic Laboratory, Athens, GA; IDEXX = IDEXX Laboratories Inc., Davis, CA; NWHC = National Wildlife Health Center, Madison, WI; USDA = United States Department of Agriculture, Beltsville, MD

$\S$ Serovars Australis, Autumnalis, Bataviae, Bratislava, Canicola, Grippotyphosa, Hardjo, Hebdomadis, Icterohaemorrhagiae, Pomona, Pyrogenes, Sejroe, Swajizak, Tarassovi $\|+2$ non-specific $\dagger++1$ anti-complementary 
Several species or genera of enteric bacteria were cultured from resident and translocated seals (Table 6). All weanling seals tested positive for E. coli, which also was common in RA seals and often was present in large numbers. Clostridium perfringens also was commonly detected in translocated and resident seals. Only weanling seals were positive for Salmonella spp. with S. muenster or S. cerro detected in four TW seals and S. arizonae detected in one RW seals. Although absent in TW seals, Vibrio spp. was detected in RW ( $V$. alginolyticus and parahaemolyticus) and RA ( $V$. alginolyticus) seals. In addition, Campylobacter sp. (small numbers, unknown species but not C. jejuni), Clostridium difficile, Edwardsiella tarda, and Aeromonas hydrophila were detected in only one or two seals.

Table 6. Prevalence (\%) of enteric bacteria. TW $=$ translocated weanlings $(n=12), \mathrm{RW}$ $=$ resident weanlings $(n=4)$, and $R A=$ resident adults $(n=9)$.

\begin{tabular}{lrrr}
\hline & TW & RW & RA \\
\hline Escherichia coli & 100 & 100 & 67 \\
Clostridium perfringens & 83 & 25 & 44 \\
Salmonella spp. & 33 & 25 & 0 \\
Vibrio spp. & 0 & 75 & 44 \\
Campylobacter sp. & 8 & 0 & 0 \\
Clostridium difficile & 8 & 0 & 0 \\
Edwardsiella tarda & 0 & 0 & 22 \\
Aeromonas hydrophila & 0 & 0 & 11 \\
\hline
\end{tabular}

There was a difference in pathogen, or pathogen antibody, prevalence between resident and translocated seals (likelihood ratio $4=11.199, p=0.024$ ). The prevalence of E. coli, C. perfringens, and Salmonella spp. was greater in TW seals, whereas resident seals had a greater prevalence of C. abortus antibodies and "other enteric" bacteria. By 
removing the "other enteric" category, however, there was no difference in infectious agent or antibody prevalence between resident and translocated seals (likelihood ratio $3=$ $5.068, p=0.196)$. Therefore, the difference in prevalence between these two groups most likely resulted from the greater prevalence of "other enteric" bacteria, primarily Vibrio spp., in resident seals relative to TW seals (likelihood ratio $_{1}=6.131, p=0.013$ ).

\section{Re-sights and first-year survival}

Eighteen resident and translocated seals were re-sighted in subsequent years (Appendix 45). All seals were re-sighted in good to excellent body condition, and most individuals and all TW seals remained at NIH. However, one RW seal (RA50) was first re-sighted at Shark's Cove, Oahu on 13 Dec 2009 and since then has been sighted repeatedly on the beaches of Oahu and Molokai (Figure 1). One RA seal (R5EG) also was sighted multiple times at FFS in 2010 and 2011, and in 2011 this individual weaned a pup. The RA seal re-sight rate was $56 \%$.

At least $50 \%$ of weanling seals translocated to NIH survived to age one. This was greater than the first-year survivorship of $31 \%$ for non-translocated weanling seals that remained at FFS. First-year survival was slightly greater for non-translocated weanling seals at NIH (69\%). For translocated and NIH-control seals, the proportion of seals alive at age one were minimum survival estimates because surveys at NIH were limited to 12 days in 2009-2011, which was $<1.0 \%$ of the survey effort at FFS.

There was a difference in weaning body size among TW, FFS-control, and NIHcontrol seals (Wilk's lambda $=0.825, F_{4,118}=2.976, p=0.022$ ). The first discriminant function explained $99.3 \%$ of the variance (canonical $r^{2}=0.173, x^{2}{ }_{4}=11.436, p=0.022$ ), 
and indicated that TW and NIH-control seals were similar in size $\left(\mathrm{AG}_{\mathrm{TW}}=109.9 \pm 1.9\right.$ $\mathrm{cm}, \mathrm{AG}_{\mathrm{NIH}-\mathrm{control}}=108.8 \pm 3.1 \mathrm{~cm} ; \mathrm{DSL}_{\mathrm{TW}}=130.0 \pm 1.9 \mathrm{~cm}, \mathrm{DSL}_{\mathrm{NIH}-\text { control }}=127.7 \pm 1.7$ $\mathrm{cm})$ and larger than FFS-control seals $(\mathrm{AG}=101.6 \pm 1.9 \mathrm{~cm}, \mathrm{DSL}=122.1 \pm 1.4 \mathrm{~cm}$; Appendix 46). $\operatorname{AG}\left(F_{2,61}=3.936, p=0.025\right)$ and DSL $\left(F_{2,60}=6.235, p=0.003\right)$ likely contributed to this difference in weaning body size, although the contribution of length was greater (function 1 loading $=0.995)$ than girth (function 1 loading $=0.747)$.

Axillary girth was the only term retained in the most parsimonious model predicting first-year survivorship $\left(B=0.132\right.$, SE of $B=0.039, x^{2}{ }_{1}=18.697, p<0.000$; Table 7). The model of best fit (Probability [first-year survival] $=\mathrm{e}^{-14.264+0.132^{*} \mathrm{AG}} /\left[1+\mathrm{e}^{-}\right.$ $14.264+0.132 * \mathrm{AG}]$ ) correctly predicted the survival outcome for $71.9 \%$ of weanling seals. Based on this model, weanling seals with greater AGs had greater probabilities of survival (odds ratio $=1.141,95 \%$ confidence interval $=1.057-1.231)$, and seals with AGs $\geq 109 \mathrm{~cm}$ were predicted to survive to age one. However, the seal with the second greatest AG $(121.5 \mathrm{~cm})$ did not survive, and a TW seal with an AG of $97 \mathrm{~cm}$ was the smallest surviving seal (Appendix 47a). The data also substantially supported the firstyear survivorship model $\left(\Delta \mathrm{AIC}_{\mathrm{C}}<2\right.$; Burnham \& Anderson 2002) that included $\mathrm{AG}$ and group $\left(x_{2}^{2}=2.780, p=0.249\right)$. As such, FFS controls had a reduced probability of survival $(B=-0.117, \mathrm{SE}$ of $B=0.755)$ and NIH controls had a greater probability of survival $(B=1.100, \mathrm{SE}$ of $B=0.902)$ relative to TW seals (Appendix $47 \mathrm{~b})$. The interaction term for group and AG was not significant $\left(x^{2}{ }_{2}=3.606, p=0.165\right)$, and firstyear survivorship also was not affected by $\operatorname{sex}\left(x^{2}{ }_{1}=0.013, p=0.908\right.$; Table 7). 
Table 7. First-year survivorship models. The change in $\mathrm{AIC}_{\mathrm{C}}\left(\Delta \mathrm{AIC}_{\mathrm{C}}\right)$ is relative to the best fitting model. The null model includes only the intercept term, $A G=$ axillary girth, $\mathrm{LL}=\log$ likelihood, $d f=$ degrees of freedom, $\mathrm{r}_{\mathrm{N}}{ }^{2}=$ Nagelkerke-adjusted $\mathrm{r}^{2}$, and $\%$ correct $=$ percentage of corrected classified survival outcomes.

\begin{tabular}{lcccccc}
\hline & $\mathrm{LL}$ & $\mathrm{AIC}_{\mathrm{C}}$ & $\Delta \mathrm{AIC}_{\mathrm{C}}$ & $d f$ & $\mathrm{r}_{\mathrm{N}}{ }^{2}$ & $\%$ correct \\
\hline $\mathrm{AG}$ & -33.818 & 71.833 & & 57 & 0.340 & 71.9 \\
$\mathrm{AG}+$ group & -32.429 & 73.535 & 1.702 & 55 & 0.382 & 70.3 \\
$\mathrm{AG}+$ sex + group & -32.422 & 75.878 & 4.045 & 54 & 0.382 & 68.8 \\
Group & -39.720 & 85.840 & 14.007 & 56 & 0.137 & 65.6 \\
Null model & -43.167 & 88.398 & 16.565 & 58 & -- & 56.3 \\
\hline
\end{tabular}

To account for the size bias of selecting TW seals, for the subset of weanling seals with $\mathrm{AG} \geq 97 \mathrm{~cm}$, there was no difference in body size among the three groups (Wilk's lambda $\left.=0.843, F_{4,94}=2.094, p=0.088\right)$. When a minimum weaning size was included in the analysis, NIH-control seals still experienced the best first-year survivorship (79\%, $\mathrm{n}=14)$ followed by TW seals $(50 \%, \mathrm{n}=12)$ and FFS-control seals $(40 \%, \mathrm{n}=25)$. In addition, for the subset of weanling seals with $\mathrm{AG} \geq 97 \mathrm{~cm}$, only $\mathrm{AG}(B=0.097, \mathrm{SE}$ of $B$ $\left.=0.046, x^{2}{ }_{1}=5.029, p=0.025\right)$ was included in the most parsimonious model, although there was again substantial empirical support of the model including AG and treatment group $\left(x_{2}^{2}=3.043, p=0.218\right.$; Appendix 48).

\section{DisCUSSION}

\section{Foraging behavior and habitat use}

Across the Hawaiian Archipelago, monk seals have variable foraging behavior and habitat use (Parrish et al. 2000, 2005, Stewart et al. 2006, Cahoon 2011). This variability likely arises in part because, as benthic foragers, the movement patterns and 
diving activity of monk seals are tightly coupled to differences in seafloor geomorphology around each island or atoll. In contrast to most other NWHI, there is little habitat $<20 \mathrm{~m}$ at $\mathrm{NIH}\left(\sim 6 \mathrm{~km}^{2}\right.$; Weiss et al. 2009). Instead, flat terraces between 40 and $100 \mathrm{~m}$ are the dominant habitat type.

Consequently, weanling seals primarily dove to depths of 40-60 m, and adult seals frequently dove to depths between 40 and $80 \mathrm{~m}$ at NIH. These dive depth ranges were slightly deeper than those of monk seals at other sites (Stewart et al. 2006, Cahoon 2011). The habitat use models for each group of seals further indicated that there was a peak in monk seal foraging activity between 50 and $60 \mathrm{~m}$. This also was the primary depth range used by foraging monk seals at FFS (Parrish et al. 2000). Monk seals also often have secondary dive modes to deeper depths (Parrish et al. 2002, Stewart et al. 2006) and may forage $>100 \mathrm{~m}$ to minimize competition with large predatory fish (Parrish et al. 2008). Resident and translocated seals at NIH, however, infrequently dove $>80 \mathrm{~m}$ with the exception of an adult female seal that repeatedly used Twin Banks. Because lesser apex predator biomass occurs at NIH relative to most other NWHI (Friedlander \& DeMartini 2002), there may be less inter-specific competition for monk seals at shallower depths. Therefore, monk seals at NIH may not be required to dive as deep to find adequate food resources free of competitors. This may represent a selective advantage for monk seals at $\mathrm{NIH}$, especially juvenile seals that may have reduced diving capabilities (Irvine et al. 2000, Noren et al. 2005).

Resident and translocated monk seals at NIH also had slightly greater dive durations $(<10 \mathrm{~min})$ compared with monk seals elsewhere in the NWHI $(<8 \mathrm{~min}$; 
Stewart \& Yochem 2004a, b) and main Hawaiian Islands (MHI; < 2 min; Cahoon 2011). Smaller body size has been associated with lesser dive durations in seals and seabirds (Schreer et al. 2001). Therefore, differences in body size (Baker \& Johanos 2004), along with the seafloor geomorphology and prey resource availability, may account for differences in dive duration among monk seals at the various breeding colonies. Despite their use of the same benthic habitat, five TW seals dove for lesser durations (4-6 min) more frequently than other seals. These five TW seals were $15 \mathrm{~kg}$ less in mass and nine $\mathrm{cm}$ less in girth than other TW and RW seals included in the foraging behavior analyses. Because TW and RW seals dove to similar depths, the lesser dive durations for these five smaller TW seals indicated these individuals had less time at the bottom to search for and capture prey. Smaller weanling seals modify their diving behavior to compensate for constraints in dive duration (Burns 1999) and can have greater foraging success than larger individuals (Irvine et al. 2000). Thus, behavioral modifications in diving activity, such as greater dive frequency, may explain why no difference in first-year survival was observed between TW seals that more frequently dove for lesser durations and TW seals that had similar dive durations as RW and RA seals.

The shallow-water $(<100 \mathrm{~m})$ terrace habitat around NIH was the primary foraging area of resident and translocated monk seals, although some individuals, including most RA seals, also used nearby submerged banks. Thus, as expected, TW and RW seals had more restricted foraging ranges than RA seals. The core and home range areas of resident and translocated monk seals at $\mathrm{NIH}$, however, were smaller than those of monk seals at other sites in the NWHI (Curtice et al. 2011), which also may be related 
to seafloor geomorphology. It is likely that this difference also resulted in part from the different techniques used to represent horizontal space use in this study (fine-scale spatial grid cells) relative to previous studies of Hawaiian monk seal home range (kernel density estimators; Littnan et al. 2007, Cahoon 2011, Curtice et al. 2011).

Before this study, the fine-scale benthic habitat use of weanling monk seals in the NWHI, which experience the greatest mortality rates (Baker \& Thompson 2007), had not been examined. The post-weaning acclimation period duration indicated that weanling monk seals remained close to land and likely were not foraging for 2-3.5 mo following weaning. Deep sand fields were identified as important foraging habitat for adult male and especially juvenile monk seals at FFS (Parrish et al. 2000, 2005). In agreement with this, TW and RW seals primarily used sandy-bottomed habitats $<13 \mathrm{~km}$ to the east of NIH. Monk seals may primarily forage in low-relief habitats because there is a greater probability of prey capture in areas with less habitat complexity (Parrish et al. 2000). Because easily caught food items often make up a greater portion of the diets of young individuals as they transition to nutritional independence (Soulsbury et al. 2008), TW and RW seals likely were exploiting sand-dwelling prey that had a decreased chance of evading capture once detected.

Newly recruited flounder $(\sim 5 \mathrm{~cm})$ may be the dominant prey item for juvenile monk seals foraging in sandy habitats at FFS (Parrish et al. 2000). Similarly, weanling monk seals at NIH also may have targeted small flounder and other cryptic prey that bury in sand and were not visible during habitat assessment surveys. TW seals demonstrated greater use of these sand fields, classified as having no surface roughness, whereas RW 
seals were associated more generally with any unconsolidated sediment. This slight difference in habitat use may be related to the smaller size and more restricted foraging ability (Schreer et al. 2001) of five TW seals. Because of their small size, these TW seals may have exploited easy-to-catch prey in deep sand fields to a greater degree than larger weanling seals at NIH.

The sandy-bottomed habitat east of NIH that TW and RW seals heavily exploited had dense aggregations of adult heart urchins (B. latecarinatus). Heart urchin aggregations were present at different sites in the fall of 2010 and 2011, indicating these aggregations were potentially seasonal. Although heart urchins are not considered a monk seal prey item, the fragile heart urchin tests may not be detectable using traditional diet techniques (Harvey 1989). Additionally, fragments of sturdier urchin tests have been found in the stomach of a young monk seal (NMFS unpublished), and other monk seal prey items have exoskeletons (e.g., lobster; Goodman-Lowe 1998). Therefore, these dense aggregations of heart urchins may be an easily acquired food source for recently weaned monk seals as they transition to nutritional independence. Habitat assessment surveys, however, did not coincide temporally with the satellite tracking period of the seals, and each camera drop site was surveyed once. Consequently, the persistence of these aggregations at each site, and whether or not heart urchins were available as prey for TW and RW seals, was unknown.

Alternatively, TW and RW seals may have been targeting secondary consumers that feed on heart urchins in the deep sand fields east of NIH. The diets of sidespot goatfish (Parupeneus pleurostigma) and crown toby (Canthigaster coronata) include 
heart urchins (Piché et al. 2010), and monk seals consume members of the Mullidea and Tetraodontidea families (Goodman-Lowe 1998, Parrish et al. 2000). Greater densities of these and other benthopelagic fishes, however, were not associated with the deep sand fields during the daytime, and diel differences in monk seal foraging activity were not observed in this study. Therefore, it is unlikely that TW and RW seals were targeting secondary consumers that do not hide or camouflage in sand.

In contrast, RA seals largely avoided areas with deep sand (no roughness) and instead foraged in areas having low to moderate surface roughness. In the NWHI, areas with low relief often are associated with lesser prey density and biomass than complex reef habitats (Parrish \& Abernathy 2006). Talus fragments aggregate prey in low-relief barren landscapes and have been identified as important foraging habitat for adult monk seals (Parrish et al. 2000). Although it was difficult to determine if some rocky features were attached outcrops or loose talus in this study, talus fragments potentially accumulated between 50-60 m on the southeastern edge of the WNB terrace, which was an area used repeatedly by at least two adult seals. At FFS, the 50-60 m ecotone (transition from soft to hard bottomed habitat), where talus accumulates, may be important adult male monk seal foraging habitat (Parrish et al. 2000). The similar use of hard-bottomed and unconsolidated sediment by RA seals may indicate they also were foraging at the ecotone. Large features, which often had increased fish density, also were associated with RA seal habitat use. Therefore, rather than using proximal sand fields, RA seals may have had greater fidelity to more distant foraging grounds because these 
areas provided reliable higher-quality prey resources or less competition (McConnell et al. 1992, Staniland et al. 2004).

\section{Health status}

In this study, among-group differences for the various hematology and serum chemistry parameters largely followed previously documented trends for pinnipeds (Bossart et al. 2001). Although ages of RW seals were unknown, greater durations from the capture date to the end of the post-weaning acclimation period for RW seals, and beach observations, indicated most RW seals were younger than TW seals. Thus, at time of sampling, RW seals likely had the most limited diving experience and TW seals likely had been fasting for longer periods. Differences in maturation, oxygen stores, diving capability, dietary intake, nutritional and fasting versus feeding status, and the duration of the fasting period likely contributed to the observed differences in blood values among TW, RW, and RA seals (Engelhardt 1979, Worthy \& Lavigne 1982, Schweigert 1993, Thompson et al. 1997, Hall 1998, Bossart et al. 2001, Reif et al. 2004, Noren et al. 2005). In addition, increased eosinophil concentrations in RA seals likely were associated with greater macroparasite infections because helminth infection intensity typically increases with age in pinnipeds (Wakelin 1996). Although endoparasites can significantly affect body condition, their importance as a cause of morbidity and mortality in monk seals remains unknown (Reif et al. 2006, Gobush et al. 2011).

Several individuals, particularly TW seals, had hematology and serum chemistry values that were outside published age-specific reference ranges for Hawaiian monk seals. The weanling reference ranges were compiled from samples collected during 
captive holding of healthy monk seals three to six months old (Banish \& Gilmartin 1988), sick and underweight weanling seals at admittance into rehabilitation, and healthy weanling seals at release from rehabilitation (Sloan 1999). Total leukocyte concentrations decreased with age in Galapagos sea lions (Zalophus wollebaeki) that were less than three months old (Brock et al. 2013). This indicates that WBC concentrations published here may be more representative of the range of values found in healthy wild weanling monk seals as young as 53 days old. In addition, ALT values for TW seals were less than previously published values for weanling monk seals fed in captivity, potentially because TW seals had been fasting for longer periods.

Based on the hematology and serum chemistry, and gross examination at the time of capture, resident and translocated seals were considered clinically healthy. The significance of small differences in hematological and serum biochemical constituents remains unclear because numerous factors affect blood values. In addition, analytes circulating in the bloodstream change rapidly, and blood values obtained from a signal sample represent a "snapshot" of individual health (Bossart et al. 2001). Thus, with the large amount of within and among individual variability for blood parameters, differences in hematology and serum chemistry values observed among the three groups of seals may be an artifact of extremely small samples sizes, especially for RW seals.

Although resident and translocated monk seals had a low prevalence of infectious agents or antibodies, infectious diseases can have substantial effects on individual health and marine mammal populations (Gulland 1995). Chlamydophila abortus may cause abortion and infertility in mammals (Brown et al. 1987, Papp et al. 1993). It is, therefore, 
concerning that many resident and translocated monk seals had positive titers for $C$. abortus antibodies. In addition, leptospirosis was implicated as the cause of death for two monk seal pups on the MHI (Littnan et al. 2007). At NIH, one resident adult seal tested positive for antibodies to Leptospira borgpetersenii serovar Ballum. Antibodies to this particular Leptospira serotype have not previously been reported in monk seals (Aguirre et al. 2007, Littnan et al. 2007). Although this is a pathogenic serovar, the significance of this finding is difficult to determine with the low titer (possible false positive or cross-reaction) and lack of paired sera samples (Bharti et al. 2003). No differences in prevalence of C. abortus or Leptospira spp., however, were observed among monk seals resident and translocated to NIH and at other sites in the Hawaiian Archipelago (Aguirre et al. 2007, Littnan et al. 2007).

Similarly, most fecal bacteria species cultured from seals in this study were present in monk seals at other sites (Aguirre 1998, Aguirre 2000, Littnan et al. 2007). Escherichia coli and C. perfringens were common in resident and translocated seals and may be part of the normal gut flora of monk seals. Salmonella spp. can be pathogenic occasionally (Thornton et al. 1998), may be endemic to the monk seal population, and may be present primarily in weaned pups (Aguirre 2000) as was observed in this study. Recently weaned monk seals spend a greater amount of time hauled out on land than older individuals. These young individuals, therefore, may experience greater exposure to Salmonellae from other monk seals or the large colonies of seabirds that breed in the NWHI (Work et al. 1998). In addition, Vibrio alginolyticus and V. parahaemolyticus, both of which also are potentially pathogenic (Xie et al. 2005), only were detected in 
resident seals. Vibrios are well adapted to the aquatic environment, although their population dynamics are poorly understood (Thompson et al. 2005). The abundance and distribution of Vibrio spp. in the marine environment around FFS and NIH need to be investigated to better elucidate differences in Vibrio exposure for monk seals at these sites. In addition, the effects of these pathogens on individual health, reproduction, and the continued population decrease of monk seals remain unclear and require further investigation.

\section{First-year survival}

Compared with the survival of non-translocated weanling seals at NIH, first-year survivorship of TW seals was slightly less. Translocated individuals often have reduced survivorship compared with individuals resident to the release site, particularly immediately following release, and first-year survival of 50\% for translocated individuals was not unusual (Ruth et al. 1998, Reinert \& Rupert 1999). Because the foraging behavior, habitat use, and health status of TW seals that survived to age one and those that did not were similar, the causes of mortality for TW seals that were not re-sighted were unknown, with two possible exceptions. Satellite tags of two TW seals stopped transmitting less than one week post-release. These two individuals, therefore, likely died within one week of being translocated. One of these TW seals never went ashore despite being released within $100 \mathrm{~m}$ of the island. Although a land-based release was not possible at NIH, releasing translocated monk seals directly onto the beach may mitigate this source of immediate mortality. In addition, another TW seal that likely died within one week of release sustained a shark bite at FFS that appeared to be well healed at the 
time of translocation. This individual's blood work and disposition were normal before and during translocation. It is possible, however, that weanling seals that have been injured by a shark attack are not ideal translocation candidates, unless the goal of the translocation effort is to mitigate shark predation (Baker et al. 2011). The fact that these two individuals did not survive, and were noteworthy in that they likely died less than one week post-release, may account for the difference in first-year survival that was observed between translocated and non-translocated weanling seals at NIH.

Axillary girth significantly predicted first-year survivorship of translocated and non-translocated weanling seals. Larger offspring size is typically associated with increased juvenile survivorship in wild populations (van Ballenberghe \& Mech 1975, Magrath 1991), and this relationship is well documented in monk seals (Craig \& Ragen 1999, Baker 2008). TW seals and non-translocated weanling seals at NIH were larger and had greater survivorship than non-translocated weanling seals that remained at FFS. This may indicate that TW and NIH-control seals had increased survivorship simply because they were larger. However, many larger weanling seals died, and there was substantial empirical support of the survivorship model including girth and group. In addition, the among-group trend in first year survivorship (NIH controls experienced the best survivorship followed by TW seals and FFS controls) was the same regardless of whether or not the smallest weanling seals $(\mathrm{AG}<97 \mathrm{~cm})$ were included in the analyses. Survival to age one, therefore, was not based solely on weaning size because there was a measurable effect of group. In addition, for the critically endangered Hawaiian monk seal population, any observed increase in juvenile survival is biologically meaningful, 
and first-year survivorship was improved for translocated weanling seals relative to weanling seals that remained at FFS.

\section{Conclusions}

Although age-related differences in foraging behavior and habitat use were observed, the movement patterns, diving activity, and habitat use of TW seals were similar to those of resident monk seals at NIH and other sites. This indicated translocated weanling seals had normal foraging activity. Furthermore, as expected, the low prevalence of infectious disease and similar health profiles of resident and translocated seals indicated the risk of spreading pathogens as a result of dispersal or translocation was minimal. Translocating weanling Hawaiian monk seals from FFS to NIH also improved their probability of survival, which was hypothesized and likely was a result of improved foraging conditions at NIH. Together these results indicated that, in the shortterm, translocations with the goal of improving foraging conditions for juvenile seals are a viable conservation strategy for Hawaiian monk seals. Continued monitoring of translocated and non-translocated control seals at FFS and NIH is needed to assess program success in terms of the relative reproductive contribution of these individuals to the monk seal population.

Fine-scale characterization of seafloor geomorphology in the context of monk seal foraging habitat selection previously was limited to FFS. Premium monk seal foraging habitat at FFS, where juvenile monk seals have the poorest survivorship (Baker \& Thompson 2007), comprised a minor fraction of the total habitat available (Parrish et al. 2000). In this study, the total area $<100$ fathom $(183 \mathrm{~m}$ ) used by foraging monk seals 
(from the bank to the southeast of NIH to Twin Banks) was $1,190 \mathrm{~km}^{2}$ (Weiss et al. 2009). The home range for all resident and translocated seals combined was slightly less than this $\left(1,096 \mathrm{~km}^{2}\right)$, although the core area used by monk seals at NIH covered less than $200 \mathrm{~km}^{2}$. Because monk seal numbers at NIH are increasing and seals broadly used areas $<200 \mathrm{~m}$ deep, a large portion of the shallow-water habitat available around this island may be optimal monk seal foraging habitat. Temporal and spatial variability in ocean productivity have been linked to variable juvenile survivorship in monk seals (Baker et al. 2007, 2012). The abundance of newly recruited fishes on sand banks, which may be the dominant prey of juvenile monk seals, may largely depend on oceanographic conditions (Parrish et al. 2005). It is also plausible that the availability of sandy habitat also could influence prey abundance, and consequently juvenile survivorship. Thus, areas that have less benthic foraging habitat for monk seals, especially relative to the number of seals using that habitat, may be more likely to have reduced juvenile survivorship during periods with unfavorable oceanographic conditions. The relationship between the spatial variability of juvenile monk seal survival and seafloor geomorphology requires further investigation. Accordingly, more systematic range-wide in situ and remote sensing surveys of the shallow-water $(<200 \mathrm{~m})$ habitat are needed to determine how much of the total shallow-water area in the NWHI $\left(13,800 \mathrm{~km}^{2}<100\right.$ fathoms; Weiss et al. 2009) actually represents optimal monk seal foraging habitat. Across a wide range of animal taxa, a dispersing individual's experience in its natal habitat has important consequences on habitat selection post-dispersal (Davis \& Stamps 2004). Because the post-weaning acclimation period for TW seals, in which 
these seals were fasting (Reiter et al. 1978), did not end until $>12$ d post-translocation, TW seals likely had only experienced stimuli in the shallow near-shore environment at their natal site of FFS. In the NWHI, near-shore habitats are quite different than the deeper habitats monk seals use for foraging (Parrish et al. 2000, Parrish \& Abernathy 2006, Weiss et al. 2009). Therefore, if natal habitat imprinting occurs in monk seals, TW seals probably first encountered cues that influenced their foraging habitat selection at $\mathrm{NIH}$, similar to RW seals. If dispersing individuals have not imprinted on foraging grounds at their natal atoll, similar post-dispersal foraging behavior, habitat use, and survival would be expected for dispersing and philopatric individuals of the same age, as was observed in this study. Although dispersal may be expected to be more detrimental to the fitness of young animals that have less experience and energy reserves than adults, the results of this study indicate that individuals that disperse with limited foraging experience likely will have similar post-dispersal foraging behavior, habitat use, and survival as philopatric individuals of the same age. These similarities in foraging activity and survival indicate that young individuals are capable of rapidly adapting to their postdispersal habitat. The ability of juveniles to rapidly adapt, forage successfully, and survive post-dispersal is particularly important to population dynamics as climate change and habitat degradation increasingly force animals to move into unfamiliar and often unpredictable habitats. 


\section{Literature Cited}

Aguirre A (1998) Hawaiian monk seal health assessment and disease status studies: a progress report. NOAA SWFSC Admin Rep H-98-10, US Department of Commerce

Aguirre A (2000) Health assessment and disease status studies of the Hawaiian monk seal (Monachus schauinslandi). NOAA SWFSC Admin Rep H-00-01, US Department of Commerce

Aguirre AA, Keefe TJ, Reif JS, Kashinsky L, Yochem PK, Saliki JT, Stott JL, Goldstein T, Dubey JP, Braun R, Antonelis G (2007) Infectious disease monitoring of the endangered Hawaiian monk seal. J Wildl Dis 43:229-241

Antonelis GA, Baker JD, Johanos TC, Braun RC, Harting AL (2006) Hawaiian monk seal (Monachus schauinslandi): status and conservation issues. Atoll Res Bull 543:75-101

Baker JD (2008) Variation in the relationship between offspring size and survival provides insight into causes of mortality in Hawaiian monk seals. Endang Species Res 5:55-64

Baker JD, Becker BL, Wurth TA, Johanos TC, Littnan CL, Henderson JR (2011) Translocation as a tool for conservation of the Hawaiian monk seal. Biol Conserv $144: 2692-2701$

Baker JD, Howell EA, Polovina JJ (2012) Relative influence of climatic variability and direct anthropogenic impact on a sub-tropical Pacific top predator, the Hawaiian monk seal. Mar Ecol Prog Ser 469:175-189

Baker JD, Johanos TC (2004) Abundance of the Hawaiian monk seal in the main Hawaiian Islands. Biol Conserv 116:103-110

Baker JD, Polovina JJ, Howell EA (2007) Effects of variable oceanic productivity on the survival of an upper trophic predator, the Hawaiian monk seal Monachus schauinslandi. Mar Ecol Prog Ser 346:277-283

Baker JD, Thompson PM (2007) Temporal and spatial variation in age-specific survival rates of a long-lived mammal, the Hawaiian monk seal. Proc R Soc Lond, B 274:407-415

Banish LD, Gilmartin WG (1988) Hematology and serum chemistry of the young Hawaiian monk seal (Monachus schauinslandi). J Wildl Dis 24:225-230 
Banish LD, Gilmartin WG (1992) Pathological findings in the Hawaiian monk seal. J Wildl Dis 28:428-434

Bélichon S, Clobert J, Massot M (1996) Are there differences in fitness components between philopatric and dispersing individuals? Acta Ecol Sin 17:503-517

Bertilsson-Friedman P (2006) Distribution and frequencies of shark-inflicted injuries to the endangered Hawaiian monk seal (Monachus schauinslandi). J Zool 268:361-368

Bharti AR, Nally JE, Ricaldi JN, Matthias MA, Diaz MM, Lovett MA, Levett PN, Gilman RH, Willig MR, Gotuzzo E, Vinetz JM (2003) Leptospirosis: a zoonotic disease of global importance. Lancet Infect Dis 3: 757-7771

Bingham BB, Noon BR (1997) Mitigation of habitat "take": application to habitat conservation planning. Conserv Biol 11:127-139

Bossart GD, Reiderson TH, Dierauf LA, Duffield DA (2001) Clinical pathology. In: Dierauf LA, Gulland FM (eds) CRC handbook of marine mammal medicine, 2nd Edition. CRC Press, Boca Raton, p 383-430

Bowler DE, Benton TG (2005) Causes and consequences of animal dispersal strategies: relating individual behavior to spatial dynamics. Biol Rev 80:205-225

Brock PM, Hall AJ, Goodman SJ, Cruz M, Acevedo-Whitehouse K (2013) Applying the tools of ecological immunology to conservation: a test case in the Galapagos sea lion. Anim Conserv 16:19-31

Brown AS, Girjes AA, Lavin MF, Timms P, Woolcock JB (1987) Chlamydial disease in koalas. Aust Vet J 64:346-350

Bryant E (2007) 2D location accuracy statistics for Fastloc ${ }^{\circledR}$ cores running firmware versions $2.2 \& 2.3$, Technical Report TR01

Burnham KP, Anderson DR (2002) Model selection and multimodel inference: a practical information-theoretic approach, second edition. Springer, Fort Collins, CO

Burns JM (1999) The development of diving behavior in juvenile Weddell seals: pushing physiological limits in order to survive. Can J Zool 77:737-747

Cahoon MK (2011) The foraging ecology of monk seals in the main Hawaiian Islands. MS thesis, University of Hawaii, HI 
Call KA, Ream RR, Johnson D, Sterling JT, Towell RG (2008) Foraging route tactics and site fidelity of adult female northern fur seal (Callorhinus ursinus) around the Pribilof Islands. Deep-Sea Res II 55:1883-1896

Calvete C, Estrada R (2004) Short-term survival and dispersal of translocated European wild rabbits. Improving the release protocol. Biol Conserv 120:507-516

Carretta JV, Forney KA, Oleson E, Martien K, Muto MM, Lowry MS, Barlow J, Baker J, Hanson B, Lynch D, Carswell L, Brownell RL, Jr, Robbins J, Mattila DK, Ralls K, Hill MC (2012) US Pacific marine mammal stock assessments: 2011. NOAA Tech Memo, NOAA-TM-NMFS-SWFSC-488, US Department of Commerce

Clobert J, Baguette M, Benton TG, Bullock JM (2012) Dispersal ecology and evolution. Oxford University Press, Oxford, UK

Collecte Localisation Satellites (2008) Argos user's manual. Collecte Localisation Satellites, Ramonville-Saint-Agne, France

Cooper H, Hedges LV (1994) The handbook of research synthesis. Russell Sage Foundation, New York, NY

Craig MP, Ragen TJ (1999) Body size, survival, and decline of juvenile Hawaiian monk seals, Monachus schauinslandi. Mar Mamm Sci 15:786-809

Curtice C, Schick RS, Dunn DC, Halpin PN (2011) Home range analysis in Hawaiian monk seals (Monachus schauinslandi) based on colony, age, and sex. Aquat Mamm $37: 360-371$

Davis JM, Stamps JA (2004) The effect of natal experience on habitat preferences. Trends Ecol Evol 19:411-416

Desch A, Wynne T, Brainard R, Friedlander A, Christensen J (2009) Oceanographic and physical setting. In: Friedlander A, Keller K, Wedding L, Clarke A, Monaco M (eds) A marine biogeographic assessment of the Northwestern Hawaiian Islands. NOAA Tech Memo, NOS NCCOS 84, Silver Spring, p 17-63

Dietz R, Teilmann J, Andersen SM, Rigét F, Olsen MT (2012) Movement and site fidelity of harbour seals (Phoca vitulina) in Kattegat, Denmark, with implications for the epidemiology of the phocine distemper virus. ICES J Mar Sci 69:1-10

Draulans D, Van Vessum J (1985) Age-related differences in the use of time and space by radio-tagged grey herons (Ardea cinerea) in winter. J Anim Ecol 54:771-780 
Engelhardt FR (1979) Haematology and plasma chemistry of captive pinnipeds and cetaceans. Aquat Mamm 7:11-20

Fieberg J, Matthiopoulos J, Hebblewhite M, Boyce MS, Frair JL (2010) Correlation and studies of habitat selection: problem, red herring, or opportunity? Philos Trans R Soc Lond B 365:2233-2244

Fischer J, Lindenmayer DB (2000) An assessment of the published results of animal relocations. Biol Conserv 96:1-11

Freitas C, Lydersen C, Fedak MA, Kovacs KM (2008) A simple new algorithm to filter marine mammal Argos locations. Mar Mamm Sci 24: 315-325

Friedlander AM, DeMartini EE (2002) Contrasts in density, size, and biomass of reef fishes between the northwestern and the main Hawaiian islands: the effects of fishing down apex predators. Mar Ecol Prog Ser 230:253-264

Gobush KS, Baker JD, Gulland FMD (2011) Effectiveness of an antihelminthic treatment in improving the body condition and survival of Hawaiian monk seals. Endang Species Res 15:29-37

Goodman-Lowe GD (1998) Diet of the Hawaiian monk seal (Monachus schauinslandi) from the Northwestern Hawaiian islands during 1991 to 1994. Mar Biol 132:535-546

Griffith B, Scott JM, Carpenter JW, Reed C (1989) Translocations as a species conservation tool: status and strategy. Science 245:477-480

Gulland FMD (1995) The impact of infectious diseases on wild animal populations - a review. In: Grenfell BT, Dobson AP (eds) Ecology of infectious diseases in natural populations. Cambridge University Press, Cambridge, p 20-51

Gusset M, Jakoby O, Müller MS, Somers MJ, Slotow R, Grimm V (2009) Dogs on the catwalk: modeling re-introduction and translocation of endangered wild dogs in South Africa. Biol Conserv 142:2774-2781

Hall AJ (1998) Blood chemistry and hematology of gray seal (Halichoerus grypus) pups from birth to postweaning. J Zoo Wildl Med 29:401-407

Harvey JT (1989) Assessment of errors associated with harbour seal (Phoca vitulina) faecal sampling. J Zool 219:101-111

Hess GR (1994) Conservation corridors and contagious disease: a cautionary note. Conserv Biol 8:256-262 
Irvine LG, Hindell MA, van den Hoff J, Burton HR (2000) The influence of body size on dive duration of underyearling southern elephant seals (Mirounga leonina). J Zool Lond 251:463-471

IUCN (1998). IUCN guidelines for re-introductions. IUCN, Gland, Switzerland

Jameson RJ, Kenyon KW, Johnson AM, Wight HM (1982) History and status of translocated sea otter populations in North America. Wildlife Soc B 10:100-107

Johanos TC, Baker JD (2011) The Hawaiian monk seal in the Northwestern Hawaiian Islands, 2004. NOAA Tech Memo, NOAA-TM-NMFS-PIFSC-28, US Department of Commerce

Kenward R (1987) Wildlife radio tagging: equipment, field techniques and data analysis. Academic Press, London, UK

Kie JG, Matthiopoulos J, Fieberg J, Powell RA, Cagnacci F, Mitchell MS, Gaillard J-M, Moorcroft PR (2010) The home-range concept: are traditional estimators still relevant with modern telemetry technology? Philos Trans R Soc Lond B 365:22212231

Kokko H, López-Sepulcre A (2006) From individual dispersal to species ranges: perspectives for a changing world. Science 313:789-791

Littnan CL, Stewart BS, Yochem PK, Braun R (2007) Survey for selected pathogens and evaluation of disease risk factors for endangered Hawaiian monk seals in the main Hawaiian Islands. EcoHealth 3:232-244

Magrath RD (1991) Nestling weight and juvenile survival in the blackbird, Turdus merula. J Anim Ecol 60:335-351

Matson TK, Goldizen AW, Jarman PJ (2004) Factors affecting the success of translocations of the black-faced impala in Namibia. Biol Conserv 116:359-365

Maxwell SM, Breed GA, Nickel BA, Makanga-Bahouna J, Pemo-Makaya E, Parnell RJ, Formia A, Ngouessono S, Godley BJ, Costa DP, Witt MJ, Coyne MS (2011) Using satellite tracking to optimize protection of long-lived marine species: olive ridley sea turtle conservation in Central Africa. PLoS ONE 6:e19905

McConnell BJ, Chambers C, Fedak MA (1992) Foraging ecology of southern elephant seals in relation to the bathymetry and productivity of the Southern Ocean. Antarct Sci 4:393-398 
Merrick RL, Loughlin TR (1997) Foraging behavior of adult female and young-of-theyear Steller sea lions in Alaska waters. Can J Zool 75:776-786

NOAA (2003) Atlas of the shallow-water benthic habitats of the Northwestern Hawaiian Islands (draft). Center for Coastal Monitoring and Assessment, Silver Springs, MD

Noren SR, Iverson SJ, Boness DJ (2005) Development of blood and muscle oxygen stores in gray seals (Halichoerus grypus): implications for juvenile diving capacity and the necessity of a terrestrial postweaning fast. Physiol Biochem Zool 78:482-490

Papp JR, Shewen PE, Gartley CJ (1993) Chlamydia psittaci infection and associated infertility in sheep. Can J Vet Res 57:185-189

Parrish FA, Abernathy K (2006) Movements of monk seals relative to ecological depth zones in the lower Northwestern Hawaiian Islands. Atoll Res Bull 543:115-130

Parrish FA, Abernathy K, Marshall GJ, Buhleier BM (2002) Hawaiian monk seals (Monachus schauinslandi) foraging in deep-water coral beds. Mar Mamm Sci 18:244-258

Parrish FA, Craig MP, Ragen TJ, Marshall GJ, Buhleier BM (2000) Identifying diurnal foraging habitat of endangered Hawaiian monk seals using a seal-mounted video camera. Mar Mamm Sci 16:392-412

Parrish FA, Marshall GJ, Buhleier B, Antonelis GA (2008) Foraging interaction between monk seals and large predatory fish in the Northwestern Hawaiian Islands. Endang Species Res 4:299-308

Parrish FA, Marshall GJ, Littnan CL, Heithaus M, Canja S, Becker B, Braun R, Antonelis GA (2005) Foraging of juvenile monk seals at French Frigate Shoals, Hawaii. Mar Mamm Sci 21:93-107

Piché J, Iverson SJ, Parrish FA, Dollar R (2010) Characterization of forage fish and invertebrates in the Northwestern Hawaiian Islands using fatty acid signatures: species and ecological groups. Mar Ecol Prog Ser 418:1-15

Powell RA (2000) Animal home ranges and territories and home range estimators. In: Boitani L, Fuller TK (eds) Research techniques in animal ecology: controversies and consequences. Columbia University Press, New York, p 65-110

Reif JS, Bachand A, Aguirre AA, Borjesson DL, Kashinsky L, Braun R, Antonelis G (2004) Morphometry, hematology, and serum chemistry in the Hawaiian monk seal (Monachus schauinslandi). Mar Mamm Sci 20:851-860 
Reif JS, Kliks MM, Aguirre AA, Borjesson DL, Kashinsky L, Braun RC, Antonelis GA (2006) Gastrointestinal helminths in the Hawaiian monk seal (Monachus schauinslandi): associations with body size, hematology, and serum chemistry. Aquat Mamm 32:157-167

Reinert HK, Rupert RR, Jr (1999) Impacts of translocations on behavior and survival of timber rattlesnakes, Crotalus horridus. J Herpetol 33:45-61

Reiter J, Stinson NL, Le Boeuf BJ (1978) Northern elephant seal development: the transition from weaning to nutritional independence. Behav Ecol Sociobiol 3:337367

Reynolds MH, Seavy NE, Vekasy MS, Klavitter JL, Laniawe LP (2008) Translocation and early post-release demography of endangered Laysan teal. Anim Conserv 11: $160-168$

Robson BW, Goebel ME, Baker JD, Ream RR, Loughlin TR, Francis RC, Antonelis GA, Costa DP (2004) Separation of foraging habitat among breeding sites of a colonial marine predator, the northern fur seal (Callorhinus ursinus). Can J Zool 82:20-29

Ruth TK, Logan KA, Sweanor LL, Hornocker MG, Temple LJ (1998) Evaluating cougar translocations in New Mexico. J Wildl Manage 62: 1264-1275

Schmelzer I (2000) Seals and seascapes: covariation in Hawaiian monk seal subpopulations and the oceanic landscape of the Hawaiian Archipelago. J Biogeogr 27:901-914

Schreer JF, Kovacs KM, O'Hara Hines RJ (2001) Comparative diving patterns of pinnipeds and seabirds. Ecol Monogr 71:137-162

Schwacke LH, Hall AJ, Townsend FI, Wells RS, Hansen LJ, Hohn AA, Bossart GD, Fair PA, Rowles TK (2009) Hematologic and serum biochemical reference intervals for free-ranging common bottlenose dolphins (Tursiops truncatus) and variation in the distributions of clinicopathologic values related to geographic sampling site. Am J Vet Res 70:973-985

Schweigert FJ (1993) Effects of energy mobilization during fasting and lactation on plasma metabolites in the grey seal (Halichoerus grypus). Comp Biochem Physiol, A $105: 347-352$

Sheean VA, Manning AD, Lindenmayer DB (2012) An assessment of scientific approaches towards species relocations in Australia. Austral Ecol 37:204-215 
Sloan A (1999) Health determination, hematology, serum chemistry, and morphometrics of Hawaiian monk seals (Monachus schauinslandi) in rehabilitation. MS thesis, University of Hawaii, HI

Soulsbury CD, Iossa G, Baker PJ, Harris S (2008) Environmental variation at the onset of independent foraging affects full-grown body mass in red fox. Proc R Soc Lond, B 275:2411-2418

Stamps JA, Swaisgood RR (2007) Someplace like home: experience, habitat selection and conservation biology. Appl Anim Behav Sci 102:392-409

Staniland IJ, Reid K, Boyd IL (2004) Comparing individual and spatial influences on foraging behavior in Antarctic fur seals Arctocephalus gazella. Mar Ecol Prog Ser 275: $263-274$

Stewart BS, Antonelis GA, Baker JD, Yochem PK (2006) Foraging biogeography of Hawaiian monk seals in the Northwestern Hawaiian Islands. Atoll Res Bull 543:131145

Stewart BS, Yochem PK (2004a) Use of marine habitats by Hawaiian monk seals (Monachus schauinslandi) from Kure Atoll: satellite-linked monitoring in 20012002. NOAA PIFSC Admin Rep H-04-01C, US Department of Commerce

Stewart BS, Yochem PK (2004b) Use of marine habitats by Hawaiian monk seals (Monachus schauinslandi) from Laysan Island: satellite-linked monitoring in 20012002. NOAA PIFSC Admin Rep H-04-02C, US Department of Commerce

Thompson JR, Pacocha S, Pharino C, Klepac-Ceraj V, Hunt DE, Benoit J, SarmaRupavtarm R, Distel DL, Polz MF (2005) Genotypic diversity within a natural coastal bacterioplankton population. Science 307:1311-1313

Thompson PM, Tollit DJ, Corpe HM, Reid RJ, Ross HM (1997) Changes in haematological parameters in relation to prey switching in a wild population of harbour seals. Funct Ecol 11:743-750

Thornton SM, Nolan S, Gulland FMD (1998) Bacterial isolates from California sea lions (Zalophus californianus), harbor seals (Phoca vitulina), and northern elephant seals (Mirounga angustirostris) admitted to a rehabilitation center along the Central California Coast, 1994-1995. J Zoo Wildl Med 29:171-176

Tremblay Y, Shaffer SA, Fowler SL, Kuhn CE, McDonald BI, Weise MJ, Bost C-A, Weimerskirch H, Crocker DE, Goebel ME, Costa DP (2006) Interpolation of animal tracking data in a fluid environment. J Exp Biol 209:128-140 
van Ballenberghe V, Mech LD (1975) Weights, growth, and survival of timber wolf pups in Minnesota. J Mammal 56:44-63

Villegas-Amtmann S, Costa DP (2010) Oxygen stores plasticity linked to foraging behavior and pregnancy in a diving predator, the Galapagos sea lion. Funct Ecol 24:785-795

Wakelin D (1996) Immunity to parasites: how parasitic infections are controlled, 2nd edition. Cambridge University Press, Cambridge, UK

Weiss J, Miller J, Hirsch E, Rooney J, Wedding L, Friedlander A (2009) Geology and benthic habitat. In: Friedlander A, Keller K, Wedding L, Clarke A, Monaco M (eds) A marine biogeographic assessment of the Northwestern Hawaiian Islands. NOAA Tech Memo, NOS NCCOS 84, Silver Spring, p 65-103

Wolf CM, Griffith B, Reed C, Temple SA (1996) Avian and mammalian translocations: update and reanalysis of 1987 survey data. Conserv Biol 10:1142-1154

Work TM, Smith MR, Duncan R (1998) Necrotizing enteritis as a cause of mortality in Laysan albatross, Diomedea immutabilis, chicks on Midway Atoll, Hawaii. Avian Dis $42: 1-5$

Worthy GAJ, Lavigne DM (1982) Changes in blood properties of fasting and feeding harp seal pups, Phoca groenlandica, after weaning. Can J Zool 60:586-592

Xie Z-Y, Hu C-Q, Chen C, Zhang L-P, Ren C-H (2005) Investigation of seven Vibrio virulence genes among Vibrio alginolyticus and Vibrio parahaemolyticus strains from the coastal mariculture system in Guangdong, China. Lett Appl Microbiol 41: 202-207 
Appendix 1. Weaning and pre-translocation capture data for weanling seals translocated to NIH on 31 Aug 2008 and 22 Aug 2009. Sex, axillary girth (AG), and dorsal standard length (DSL) were determined within two weeks of weaning (without sedation; Johanos $\&$ Baker 2011) and again before translocation (under sedation). Mass was determined at the pre-translocation capture date only. Ranges were calculated for ages at the time of translocation when exact birth dates were unknown.

\begin{tabular}{|c|c|c|c|c|c|c|c|c|c|}
\hline \multirow[b]{2}{*}{ ID } & \multirow[b]{2}{*}{ Sex } & \multicolumn{3}{|c|}{ Weaning } & \multicolumn{4}{|c|}{ Pre-translocation } & \multirow{2}{*}{$\begin{array}{c}\text { Age at } \\
\text { translocation } \\
\text { (d) }\end{array}$} \\
\hline & & Date & $\begin{array}{l}\mathrm{AG} \\
(\mathrm{cm})\end{array}$ & $\begin{array}{l}\text { DSL } \\
(\mathrm{cm})\end{array}$ & Date & $\begin{array}{l}\mathrm{AG} \\
(\mathrm{cm})\end{array}$ & $\begin{array}{l}\mathrm{DSL} \\
(\mathrm{cm})\end{array}$ & $\begin{array}{c}\text { Mass } \\
(\mathrm{kg})\end{array}$ & \\
\hline \multicolumn{10}{|c|}{2008 translocations } \\
\hline YW07 & $\mathrm{F}$ & $11 \mathrm{Jul}$ & 112.0 & 137.5 & 28 Aug & 102.0 & 134.0 & 58.4 & 93 \\
\hline YW11 & $\mathrm{F}$ & 29-30 Jul & 115.5 & 134.5 & 29 Aug & 110.0 & 137.0 & 72.8 & $75-76$ \\
\hline YW19 & $\mathrm{M}$ & $24 \mathrm{Jul}$ & 109.0 & 132.0 & 29 Aug & 109.0 & 127.0 & 55.0 & $75-76$ \\
\hline YW24 & $\mathrm{F}$ & 11 Aug & 109.0 & 132.0 & 28 Aug & 102.0 & 131.0 & 64.0 & 60 \\
\hline YW27 & $\mathrm{M}$ & 13 Aug & 106.0 & 129.0 & 28 Aug & 101.5 & 135.5 & 59.8 & 57 \\
\hline YW29 & $\mathrm{F}$ & 18 Aug & 119.0 & 141.0 & 28 Aug & 120.0 & 141.0 & 87.4 & 57 \\
\hline \multicolumn{10}{|c|}{2009 translocations } \\
\hline YA08 & $\mathrm{F}$ & 17 Jun & 114.5 & 130.0 & 10 Aug & 113.5 & 132.0 & 64.6 & $\geq 106$ \\
\hline YA10 & $\mathrm{M}$ & 21 Jun & 117.0 & 128.0 & 11 Aug & 114.5 & 135.5 & 69.2 & $\geq 106$ \\
\hline YA20 & $\mathrm{M}$ & $03 \mathrm{Jul}$ & 99.5 & 119.0 & 14 Aug & 89.0 & 120.0 & 39.4 & 86 \\
\hline YA22 & $\mathrm{F}$ & $15 \mathrm{Jul}$ & 108.0 & 124.0 & 17 Aug & 105.0 & 126.0 & 55.0 & 76 \\
\hline YA26 & $\mathrm{F}$ & $17 \mathrm{Jul}$ & 112.0 & 133.0 & $11 \mathrm{Aug}$ & 111.0 & 134.0 & 71.0 & 80 \\
\hline YA42 & $\mathrm{M}$ & $24 \mathrm{Jul}$ & 97.0 & 120.0 & 13 Aug & 97.0 & 120.5 & 45.4 & $64-65$ \\
\hline
\end{tabular}

Johanos TC, Baker JD (2011) The Hawaiian monk seal in the Northwestern Hawaiian Islands, 2004. NOAA Tech Memo, NOAA-TM-NMFS-PIFSC-28, US Department of Commerce 
Appendix 2. Capture data for resident NIH seals. Sex, axillary girth (AG), and dorsal standard length (DSL) were determined for all resident seals, but no adult (A) or subadult (SA) seals were weighed. The weaning date was unknown for all but one resident weanling (W) seal (RA58 = 3-4 Sep 2009). It, therefore, was unknown whether or not these morphometric measurements were collected within two weeks of weaning. Birth dates were not known for resident weanling seals.

\begin{tabular}{ccccccc}
\hline ID & $\begin{array}{c}\text { Age } \\
\text { class }\end{array}$ & Sex & Capture date & $\begin{array}{c}\text { AG } \\
(\mathrm{cm})\end{array}$ & $\begin{array}{c}\text { DSL } \\
(\mathrm{cm})\end{array}$ & $\begin{array}{c}\text { Mass } \\
(\mathrm{kg})\end{array}$ \\
\hline RW62 & $\mathrm{W}$ & F & 10 Sep 2008 & 119.0 & 136.0 & 74.2 \\
RW64 & W & M & 10 Sep 2008 & 124.5 & 136.0 & 81.2 \\
RW66 & W & F & 10 Sep 2008 & 80.0 & 113.5 & 35.6 \\
RW68 & W & M & 10 Sep 2008 & 117.0 & 125.5 & 61.8 \\
RA50 & W & M & 01 Sep 2009 & 116.0 & 129.5 & 77.4 \\
RA52 & W & M & 01 Sep 2009 & 119.0 & 131.0 & 75.0 \\
RA54 & W & M & 01 Sep 2009 & 115.0 & 128.0 & 76.4 \\
RA58 & W & M & 04 Sep 2009 & 105.0 & 120.5 & 61.8 \\
R2BK & A & M & 10 Sep 2008 & 173.0 & 196.0 & -- \\
R2BU & A & M & 11 Sep 2008 & 161.0 & 205.0 & -- \\
R2BW & SA & F & 11 Sep 2008 & 107.0 & 156.6 & -- \\
R2BY & A & M & 11 Sep 2008 & 122.0 & 189.0 & -- \\
R5EE & A & F & 01 Sep 2009 & 141.5 & 210.0 & -- \\
R5EG & A & F & 02 Sep 2009 & 126.5 & 201.0 & -- \\
R5EI & A & M & 02 Sep 2009 & 139.5 & 194.5 & -- \\
R5EM & A & M & 04 Sep 2009 & 149.5 & 205.0 & -- \\
R5EP & A & F & 04 Sep 2009 & 130.5 & 186.5 & -- \\
\hline
\end{tabular}


Appendix 3. Fast-GPS filtering algorithm steps.

Removal of locations with:

1. Transit speeds $>2 \mathrm{~m} / \mathrm{s}$ (iterative) $\dagger$

- Unless distance between consecutive locations $<5 \mathrm{~km}$ 末

2. Turn angles between consecutive locations:

$\geq 165^{\circ}$, if incoming and outgoing straight-path distances $\geq 2.5 \mathrm{~km} \ddagger$

$\geq 155^{\circ}$, if incoming and outgoing straight-path distances $\geq 5.0 \mathrm{~km}:$

- Unless location classified as "good" location by tag manufacturer§

3. Location quality indicator "residual" values $>100$, classified by tag manufacturer as possibly erroneous

$\dagger$ From McConnell et al. 1992

$\$$ From Freitas et al. 2008

$\S$ Location quality indicator "residual" values $<20$ and signal detected by $\geq$ six satellites

Freitas C, Lydersen C, Fedak MA, Kovacs KM (2008) A simple new algorithm to filter marine mammal Argos locations. Mar Mamm Sci 24:315-325

McConnell BJ, Chambers C, Fedak MA (1992) Foraging ecology of southern elephant seals in relation to the bathymetry and productivity of the Southern Ocean. Antarct Sci 4:393-398 
Appendix 4. Spatial grid cell methods to create utilization distributions (UDs).

Individual UDs:

1. Numbers of interpolated locations per grid cell, excluding locations on NIH or within $100 \mathrm{~m}$ of the island's shoreline, were determined for each seal

2. These counts were normalized to proportions of locations per grid cell using the total number of interpolated at-sea locations

3. Cumulative proportions of locations per grid cell were determined for each seal by ranking the proportions of locations per cell from largest to smallest such that all cells with the same proportion of locations were summed together

4. UDs with $10 \%$ isopleths were generated from the cumulative proportions and included all used cells with cumulative proportions $\leq$ each $10 \%$ isopleth

\section{Group UDs:}

1. Proportions of locations per cell were averaged cell-by-cell for all seals in each group with unused cells assigned a proportion of zero

2. Group cumulative proportions and UDs were determined using the same approach as described for the individual seals 
Appendix 5. Summary of 28 video camera drop sites on NIH terrace. Latitude and longitude are the start drift coordinates given in decimal degrees. A drift distance could not be calculated for Site 15 because coordinates were not recorded at the end of the drift.

\begin{tabular}{|c|c|c|c|c|c|}
\hline Site & Drop Date & $\begin{array}{l}\text { Drift duration } \\
\text { (min:s) }\end{array}$ & $\begin{array}{l}\text { Drift distance } \\
\text { (m) }\end{array}$ & Latitude $\left({ }^{\circ} \mathrm{N}\right)$ & Longitude $\left({ }^{\circ} \mathrm{W}\right)$ \\
\hline 1 & 17 Nov 2010 & $5: 00$ & 156.4 & 23.07064 & 161.92410 \\
\hline 2 & 17 Nov 2010 & $5: 00$ & 149.7 & 23.06347 & 161.90971 \\
\hline 3 & 17 Nov 2010 & $5: 00$ & 500.8 & 23.06399 & 161.89694 \\
\hline 4 & 19 Aug 2011 & $1: 00$ & 35.8 & 23.09543 & 161.88887 \\
\hline 5 & 20 Apr 2011 & $1: 43$ & 10.9 & 23.10658 & 161.86600 \\
\hline 6 & 20 Apr 2011 & $4: 15$ & 22.8 & 23.11698 & 161.90605 \\
\hline 7 & 20 Apr 2011 & $1: 42$ & 25.3 & 23.14312 & 161.91235 \\
\hline 8 & 20 Apr 2011 & $3: 20$ & 26.2 & 23.12390 & 161.93880 \\
\hline 9 & 20 Apr 2011 & $2: 08$ & 18.0 & 23.11013 & 161.97480 \\
\hline 10 & 20 Apr 2011 & $2: 00$ & 5.4 & 23.09660 & 161.99273 \\
\hline 11 & 20 Apr 2011 & $2: 28$ & 5.4 & 23.07940 & 162.00387 \\
\hline 12 & 20 Apr 2011 & $1: 43$ & 23.4 & 23.06963 & 161.97953 \\
\hline 13 & 20 Apr 2011 & $1: 57$ & 5.8 & 23.09260 & 161.93777 \\
\hline 14 & 17 Nov 2010 & $5: 00$ & 306.3 & 23.04846 & 161.90721 \\
\hline 15 & 18 Nov 2010 & $5: 00$ & -- & 23.03637 & 161.91400 \\
\hline 16 & 20 Apr 2011 & $4: 59$ & 129.8 & 22.99955 & 161.88115 \\
\hline 17 & 20 Apr 2011 & $2: 50$ & 53.4 & 22.98682 & 161.87077 \\
\hline 18 & 18 Nov 2010 & $5: 00$ & 79.4 & 23.01794 & 161.87579 \\
\hline 19 & 18 Nov 2010 & $5: 00$ & 76.8 & 23.02452 & 161.88440 \\
\hline 20 & 18 Nov 2010 & $5: 00$ & 81.7 & 23.02813 & 161.86255 \\
\hline 21 & 18 Nov 2010 & $5: 00$ & 28.9 & 23.06266 & 161.83026 \\
\hline 22 & 18 Nov 2010 & $5: 00$ & 189.9 & 23.06655 & 161.83946 \\
\hline 23 & 18 Nov 2010 & $5: 00$ & 236.2 & 23.08175 & 161.82527 \\
\hline 24 & 18 Nov 2010 & $5: 00$ & 241.2 & 23.09314 & 161.81461 \\
\hline 25 & 18 Nov 2010 & $3: 00$ & 185.2 & 23.07133 & 161.86595 \\
\hline 26 & 19 Aug 2011 & $1: 46$ & 59.5 & 23.06068 & 161.88557 \\
\hline 27 & 20 Apr 2011 & $2: 49$ & 63.7 & 23.05863 & 161.77873 \\
\hline 28 & 20 Apr 2011 & $2: 42$ & 47.9 & 23.11068 & 161.80015 \\
\hline
\end{tabular}


Appendix 6. Summary of 17 video camera drop sites on WNB terrace. Latitude and longitude are the start drift coordinates given in decimal degrees.

\begin{tabular}{cccccc}
\hline Site & Drop Date & $\begin{array}{c}\text { Drift duration } \\
(\mathrm{min}: \mathrm{s})\end{array}$ & $\begin{array}{c}\text { Drift distance } \\
(\mathrm{m})\end{array}$ & Latitude $\left({ }^{\mathrm{O}} \mathrm{N}\right)$ & Longitude $\left({ }^{\circ} \mathrm{W}\right)$ \\
\hline 29 & 19 Aug 2011 & $1: 48$ & 62.1 & 23.02313 & 162.14617 \\
30 & 19 Aug 2011 & $1: 00$ & 32.7 & 23.04083 & 162.15408 \\
31 & 19 Aug 2011 & $1: 00$ & 40.4 & 23.02588 & 162.16918 \\
32 & 19 Aug 2011 & $1: 00$ & 44.3 & 23.00552 & 162.17890 \\
33 & 19 Aug 2011 & $1: 05$ & 48.2 & 22.99007 & 162.16382 \\
34 & 20 Apr 2011 & $1: 36$ & 8.7 & 22.95600 & 162.15818 \\
35 & 20 Apr 2011 & $1: 32$ & 37.7 & 22.93793 & 162.16930 \\
36 & 20 Apr 2011 & $1: 22$ & 29.1 & 22.93413 & 162.17742 \\
37 & 20 Apr 2011 & $2: 34$ & 56.4 & 22.93048 & 162.16185 \\
38 & 20 Apr 2011 & $1: 13$ & 35.0 & 22.90462 & 162.18708 \\
39 & 20 Apr 2011 & $1: 21$ & 23.3 & 22.91850 & 162.18622 \\
40 & 20 Apr 2011 & $1: 25$ & 44.3 & 22.92625 & 162.19193 \\
41 & 20 Apr 2011 & $1: 46$ & 44.7 & 22.91348 & 162.19747 \\
42 & 20 Apr 2011 & $1: 21$ & 46.3 & 22.92000 & 162.20487 \\
43 & 19 Aug 2011 & $1: 00$ & 34.3 & 23.04958 & 162.24177 \\
44 & 19 Aug 2011 & $1: 00$ & 34.3 & 23.04432 & 162.24502 \\
45 & 19 Apr 2011 & $2: 21$ & 88.5 & 23.04232 & 162.21082 \\
\hline
\end{tabular}


Appendix 7. Manual techniques used to perform complete blood counts and partial serum chemistry analysis in the field. $\mathrm{WBC}=$ white blood cell, $\mathrm{RBC}=$ red blood cell, and $\mathrm{HGB}=$ hemoglobin.

\begin{tabular}{|c|c|}
\hline Blood Parameter & Method \\
\hline WBC counts & $\begin{array}{l}\text { Unopette }{ }^{\circledR} \text { WBC/platelet system (Becton, } \\
\text { Dickinson and Company, Franklin Lakes, NJ) }\end{array}$ \\
\hline WBC differentials & Stained blood smear \\
\hline RBC counts & $\begin{array}{l}10 \mu \mathrm{L} \text { EDTA whole blood diluted in } 0.85 \% \mathrm{NaCl} \\
(1: 200) \text { - multiply count from five small } \\
\text { hemocytometer grids by } 10,000 \text { (duplicate counts } \\
\text { within } 10 \% \text { of each other) }\end{array}$ \\
\hline HGB (2009 samples) & $\begin{array}{l}\text { HemoCue }{ }^{\circledR} \text { Hb } 201+\text { System (HemoCue, Inc., } \\
\text { Cypress, CA) }\end{array}$ \\
\hline Hematocrit & Microhematocrit centrifuge \\
\hline Total solids & Refractometer \\
\hline Partial serum chemistry panel & $\begin{array}{l}\text { i-STAT® System and EC } 8+\text { and creatinine } \\
\text { cartridges (Abbott Laboratories, Abbott Park, IL) }\end{array}$ \\
\hline
\end{tabular}


Appendix 8. Post-weaning acclimation period summary. The post-weaning acclimation period duration was calculated as the number of days from the weaning date to the date marking the end of the acclimation period for each translocated weanling seal. This period also was approximated using the resident weanling seal capture date for each year of this study (10 Sep 2008 and 1 Sep 2009) because the weaning date was unknown for resident weanling seals.

\begin{tabular}{cccc}
\hline ID & $\begin{array}{c}\text { Date acclimation } \\
\text { period ended }\end{array}$ & $\begin{array}{c}\text { Acclimation period } \\
\text { duration (d) }\end{array}$ & $\begin{array}{c}\text { Capture date to end of } \\
\text { acclimation period (d) }\end{array}$ \\
\hline \multicolumn{2}{c}{ Translocated } & & \\
YW07 & 21 Oct 2008 & 102 & 41 \\
YW11 & 20 Oct 2008 & 83 & 40 \\
YW19 & 21 Oct 2008 & 89 & 41 \\
YW24 & 16 Oct 2008 & 66 & 36 \\
YW29 & 24 Oct 2008 & 67 & 44 \\
YA08 & 23 Sep 2009 & 98 & 22 \\
YA10 & 02 Oct 2009 & 103 & 31 \\
YA20 & 13 Sep 2009 & 72 & 12 \\
YA26 & 20 Oct 2009 & 95 & 49 \\
YA42 & 26 Sep 2009 & 64 & 25 \\
Resident & & & \\
RW62 & 02 Nov 2008 & -- & 53 \\
RW64 & 15 Nov 2008 & -- & 36 \\
RW68 & 16 Oct 2008 & -- & 71 \\
RA52 & 11 Nov 2009 & -- & 92 \\
RA54 & 02 Dec 2009 & -- & \\
\hline
\end{tabular}


Appendix 9. Satellite tracking summary for individuals excluded from analyses. The satellite tracking duration was calculated from the date of translocation, or capture for the resident seals, to the date of last satellite transmission with the exception of two weanling seals that transmitted beyond the end of the acclimation period. The number of GPS locations and dive records are the number received during the defined tracking duration for each seal. Ranges represent the number of dive records received for each of the three dive histogram data types.

\begin{tabular}{|c|c|c|c|c|}
\hline ID & $\begin{array}{l}\text { Date of last satellite } \\
\text { transmission }\end{array}$ & $\begin{array}{l}\text { Satellite tracking } \\
\text { duration }(\mathrm{d})\end{array}$ & $\begin{array}{l}\text { Number of } \\
\text { locations }\end{array}$ & $\begin{array}{l}\text { Number of } \\
\text { dive records }\end{array}$ \\
\hline \multicolumn{5}{|c|}{ Translocated weanlings } \\
\hline YW11 & 16 Nov 2008 & $26 \dagger$ & 123 & $13-15$ \\
\hline YW27 & 04 Sep 2008 & 4 & 8 & 1 \\
\hline YW29 & 30 Oct 2008 & $6 \dagger$ & 109 & $2-4$ \\
\hline YA22 & 07 Sep 2009 & 6 & 56 & $6-7$ \\
\hline \multicolumn{5}{|c|}{ Resident weanlings } \\
\hline RW66 & 14 Oct 2008 & 34 & 63 & $2-15$ \\
\hline RA50 & 04 Nov 2009 & 64 & 155 & $43-45$ \\
\hline RA58 & 28 Sep 2009 & 24 & 12 & $20-24$ \\
\hline \multicolumn{5}{|c|}{ Resident adults } \\
\hline R2BW & 18 Sep 2008 & 6 & 19 & $0-3$ \\
\hline R5EP & 25 Sep 2009 & 20 & 203 & $15-21$ \\
\hline
\end{tabular}

$\dagger$ calculated from end of post-weaning acclimation period 
Appendix 10. Filtered Fast-GPS locations for individuals excluded from analyses. The different colored symbols represent the locations for separate individuals in each group: translocated weanling $(\mathrm{TW})$ seals: red $=$ YA22, blue $=$ YW27, green $=$ YW29, black $=$ YW11; resident weanling $(\mathrm{RW})$ seals: red $=\mathrm{RA} 58$, blue $=\mathrm{RW66}$, black $=\mathrm{RA} 50$; and resident adult (RA) seals: red $=\mathrm{R} 2 \mathrm{BW}$, black $=\mathrm{R} 5 \mathrm{EP}$. $\mathrm{NIH}$ is located where there are an increased number of red dots, and the $200-\mathrm{m}$ isobath is indicated by the gray line.
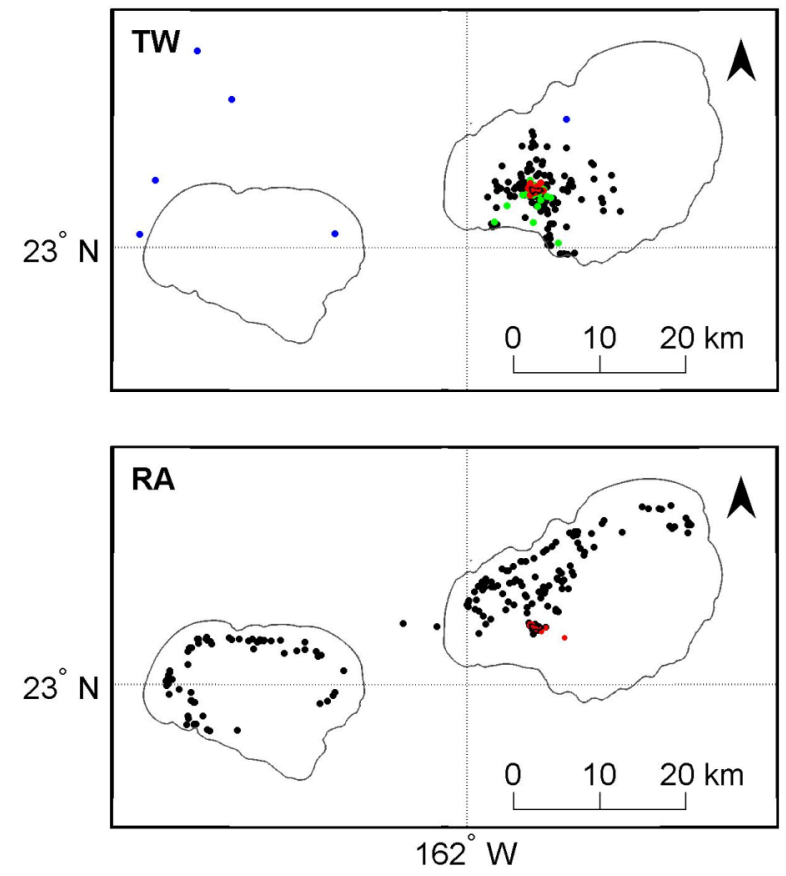

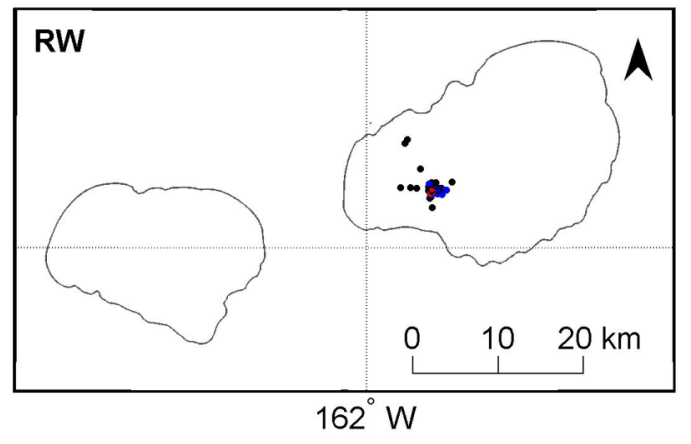


Appendix 11. Satellite tracking summary for individuals included in analyses. Tracking duration was calculated from the end of the post-weaning acclimation period for weanling seals and from the capture date for adult seals. The total number of uninterpolated locations retained after filtering were used to determine mean transmission intervals between consecutive GPS locations. A signal was received by only four satellites for many Fast-GPS locations that passed the filtering criteria, and the associated location errors may exceed $810 \mathrm{~m}$ in these cases (Bryant 2007). A two-hour interpolation interval, therefore, was used because this interval resulted in a mean distance between consecutive locations that was greater than the spatial accuracy of the tracking data for each individual (Tremblay et al. 2006).

\begin{tabular}{|c|c|c|c|c|c|c|c|}
\hline \multirow{3}{*}{ ID } & \multirow{3}{*}{$\begin{array}{l}\text { Last satellite } \\
\text { transmission } \\
\text { date }\end{array}$} & \multirow{3}{*}{$\begin{array}{l}\text { Satellite } \\
\text { tracking } \\
\text { duration } \\
\text { (d) }\end{array}$} & \multicolumn{3}{|c|}{ Uninterpolated locations } & \multirow{2}{*}{\multicolumn{2}{|c|}{$\begin{array}{c}\text { Mean distance } \\
\text { between interpolated } \\
\text { locations }(\mathrm{m}) \\
\end{array}$}} \\
\hline & & & \multirow{2}{*}{$\begin{array}{l}\text { Percent } \\
\text { filtered }\end{array}$} & \multirow{2}{*}{$\begin{array}{c}\text { Total } \\
\text { number }\end{array}$} & \multirow{2}{*}{$\begin{array}{c}\text { Mean } \\
\text { interval } \\
\text { (h:min) } \\
\end{array}$} & & \\
\hline & & & & & & 1-h & 2-h \\
\hline \multicolumn{8}{|c|}{ Translocated weanlings } \\
\hline YW07 & 28 Apr 2009 & 189 & 1.1 & 850 & $5: 21$ & 531.1 & 1035.1 \\
\hline YW19 & 21 Feb 2009 & 123 & 0.6 & 765 & $3: 52$ & 437.9 & 850.8 \\
\hline YW24 & 07 May 2009 & 202 & 1.3 & 827 & $5: 53$ & 542.1 & 1067.7 \\
\hline YA08 & 29 May 2010 & 247 & 0.6 & 1699 & $3: 30$ & 585.3 & 1137.1 \\
\hline YA10 & 26 Jan 2010 & 116 & 1.0 & 567 & $4: 56$ & 462.0 & 902.4 \\
\hline YA20 & 13 Dec 2009 & 91 & 1.5 & 473 & $4: 41$ & 438.2 & 852.0 \\
\hline YA26 & 02 Feb 2010 & 104 & 1.6 & 442 & $5: 43$ & 497.4 & 976.1 \\
\hline YA42 & 13 May 2010 & 229 & 0.9 & 1696 & $3: 15$ & 612.9 & 1183.4 \\
\hline \multicolumn{8}{|c|}{ Resident weanlings } \\
\hline RW62 & 03 Apr 2009 & 152 & 0.8 & 810 & $4: 32$ & 691.1 & 1353.9 \\
\hline RW64 & 10 Mar 2009 & 115 & 0.8 & 574 & $4: 50$ & 508.4 & 992.6 \\
\hline RW68 & 31 May 2009 & 226 & 1.4 & 1005 & $5: 25$ & 430.6 & 842.8 \\
\hline RA52 & 26 Dec 2009 & 44 & 0.6 & 361 & $2: 58$ & 557.3 & 1071.7 \\
\hline RA54 & 13 Apr 2010 & 132 & 1.5 & 894 & $3: 34$ & 507.6 & 977.2 \\
\hline \multicolumn{8}{|c|}{ Resident adults } \\
\hline R2BK & 29 Oct 2008 & 47 & 0.4 & 271 & $4: 13$ & 643.1 & 1255.0 \\
\hline R2BU & 09 Dec 2008 & 89 & 1.2 & 488 & $4: 24$ & 880.7 & 1730.4 \\
\hline R2BY & 28 Nov 2008 & 77 & 2.3 & 236 & $7: 56$ & 543.9 & 1078.7 \\
\hline R5EE & 01 May 2010 & 241 & 0.5 & 2839 & $2: 03$ & 874.0 & 1702.6 \\
\hline R5EG & 14 Dec 2009 & 102 & 1.5 & 834 & $2: 58$ & 631.9 & 1213.2 \\
\hline R5EI & 26 Nov 2009 & 84 & 1.1 & 619 & $3: 17$ & 554.7 & 1072.6 \\
\hline R5EM & 22 Oct 2009 & 47 & 0.4 & 492 & $2: 18$ & 554.3 & 1075.3 \\
\hline
\end{tabular}


Bryant E (2007) 2D location accuracy statistics for Fastloc ${ }^{\circledR}$ cores running firmware versions $2.2 \& 2.3$, Technical Report TR01

Tremblay Y, Shaffer SA, Fowler SL, Kuhn CE, McDonald BI, Weise MJ, Bost C-A, Weimerskirch H, Crocker DE, Goebel ME, Costa DP (2006) Interpolation of animal tracking data in a fluid environment. J Exp Biol 209:128-140 
Appendix 12. Maximum dive depth and duration bins used by each individual.

\begin{tabular}{ccc}
\hline ID & Maximum depth bin (m) & Maximum duration bin (min) \\
\hline Translocated & weanlings & \\
YW07 & $160-200$ & $8-10$ \\
YW19 & $120-140$ & $8-10$ \\
YW24 & $160-200$ & $12-15$ \\
YA08 & $200-250$ & $12-15$ \\
YA10 & $120-140$ & $20-25$ \\
YA20 & $60-80$ & $10-20$ \\
YA26 & $140-160$ & $>25$ \\
YA42 & $140-160$ & $12-15$ \\
Resident weanlings & \\
RW62 & $200-250$ & $12-15$ \\
RW64 & $80-100$ & $12-15$ \\
RW68 & $200-250$ & $12-15$ \\
RA52 & $200-250$ & $20-25$ \\
RA54 & $250-300$ & $>25$ \\
Resident adults & & \\
R2BK & $80-100$ & $20-25$ \\
R2BU & $160-200$ & $>25$ \\
R2BY & $160-200$ & $>25$ \\
R5EE & $200-250$ & $>25$ \\
R5EG & $80-100$ & -25 \\
R5EI & $80-100$ & \\
R5EM & $120-140$ & \\
\hline
\end{tabular}


Appendix 13. TW seals' dive depth frequency histograms for each six-hour period. Period start times are indicated below the x-axes, and numbers in parentheses are the total number of dives logged during each period.
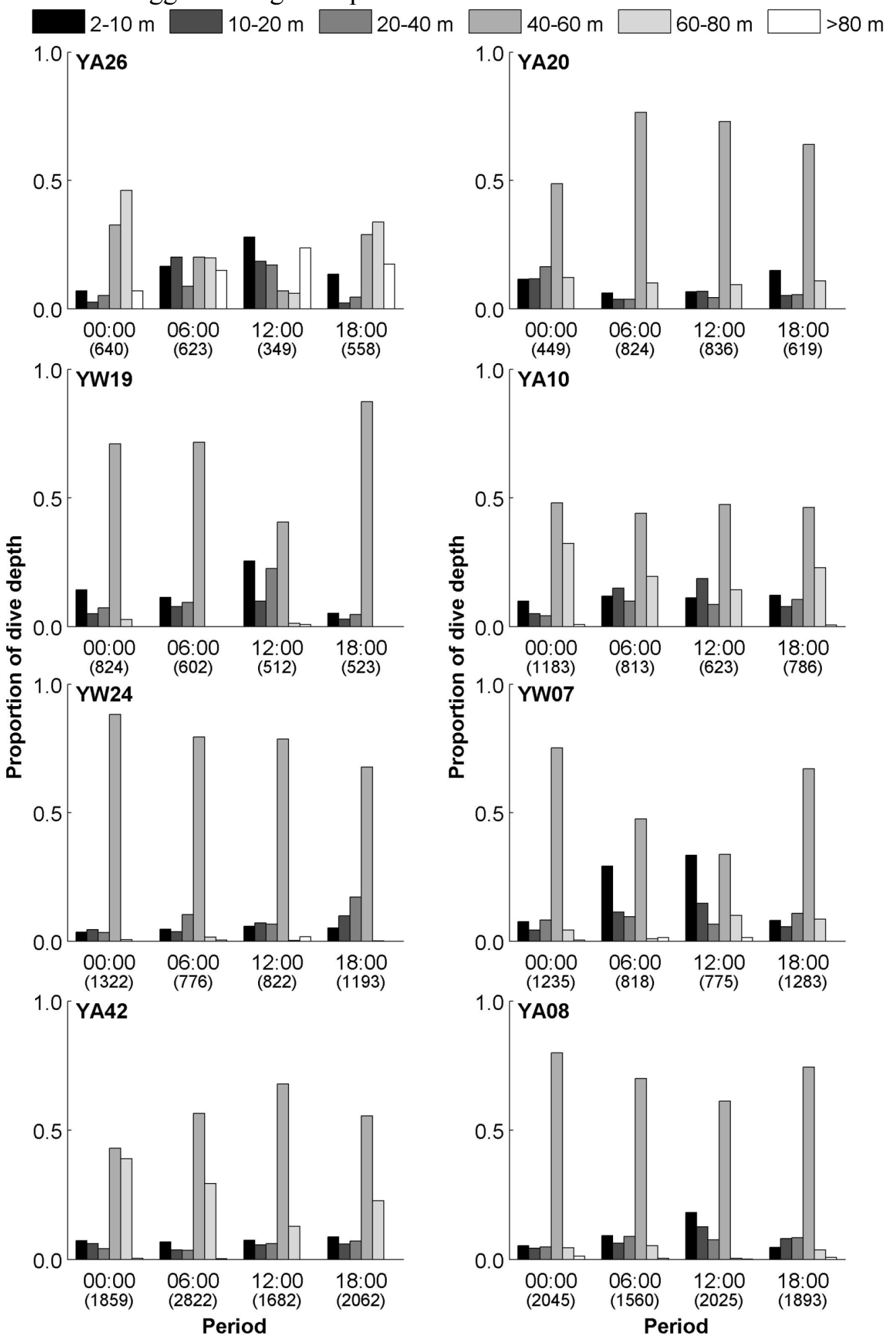
Appendix 14. RW seals' dive depth frequency histograms for each six-hour period. Period start times are indicated below the $\mathrm{x}$-axes, and numbers in parentheses are the total number of dives logged during each period.

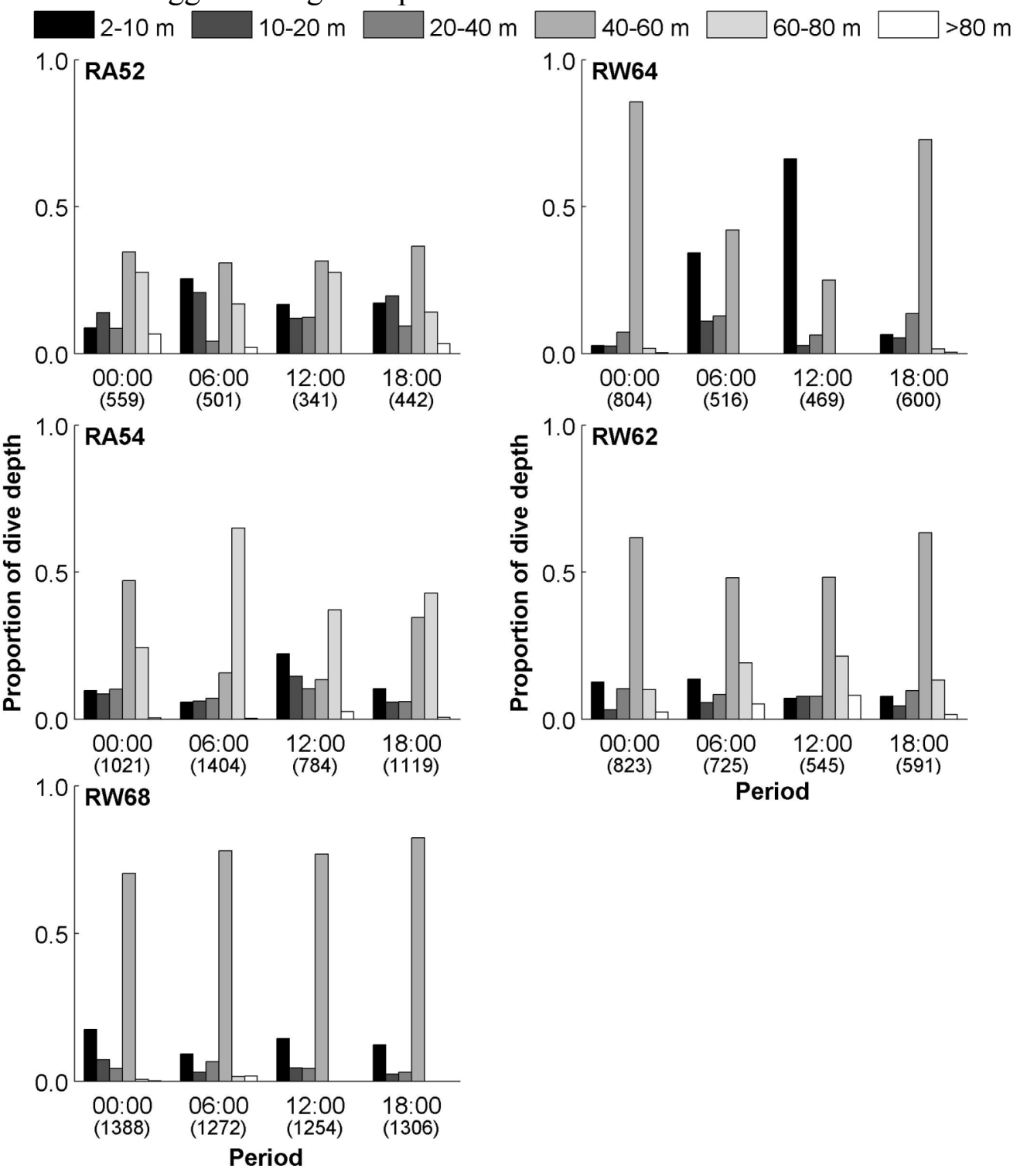


Appendix 15. RA seals' dive depth frequency histograms for each six-hour period. Period start times are indicated below the x-axes, and numbers in parentheses are the total number of dives logged during each period.

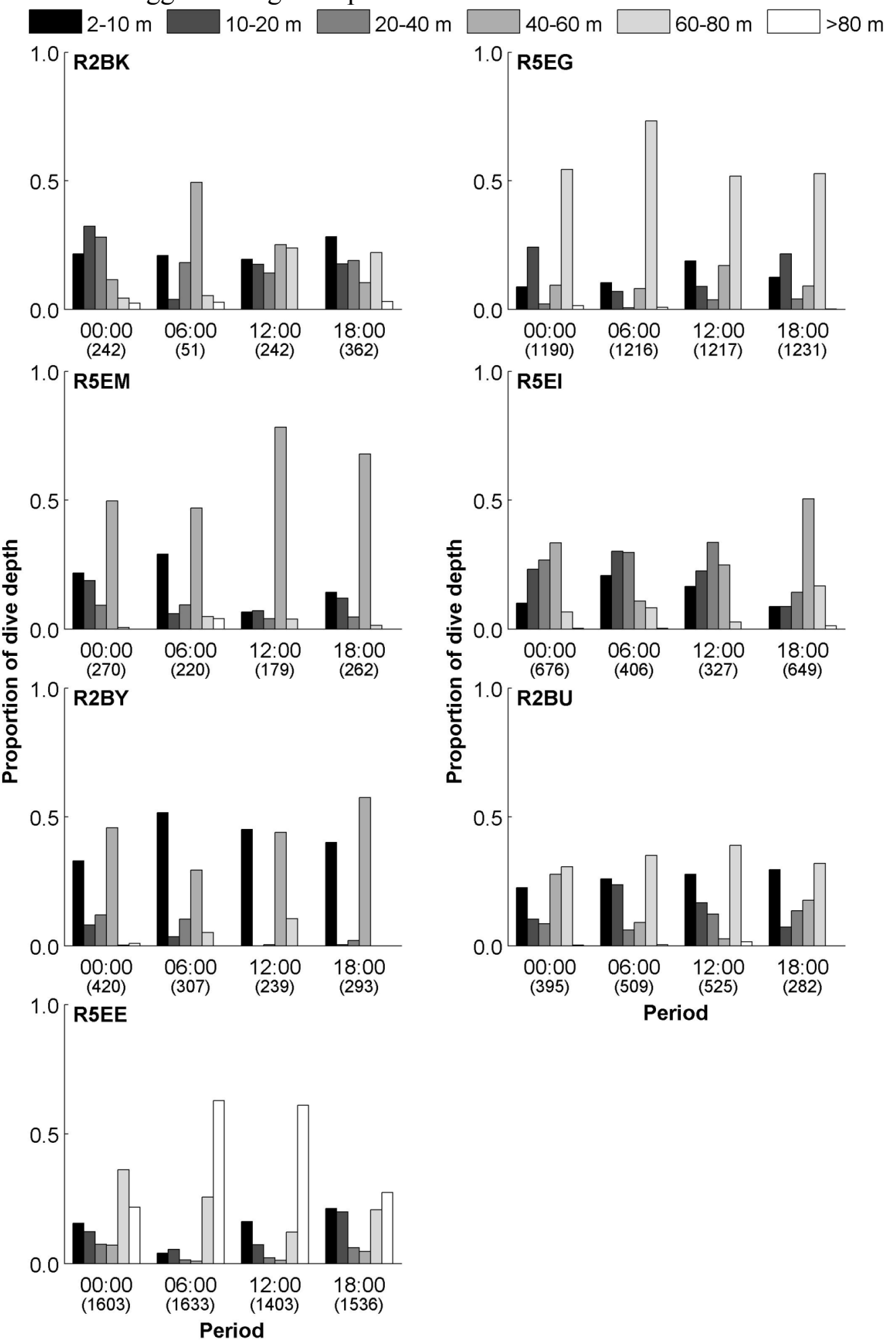


Appendix 16. Individual dive depth frequency histograms. Numbers in parentheses below the $\mathrm{x}$-axes are the number of records (n) received for each individual in the translocated weanling (TW), resident weanling (RW), and resident adult (RA) seal groups.
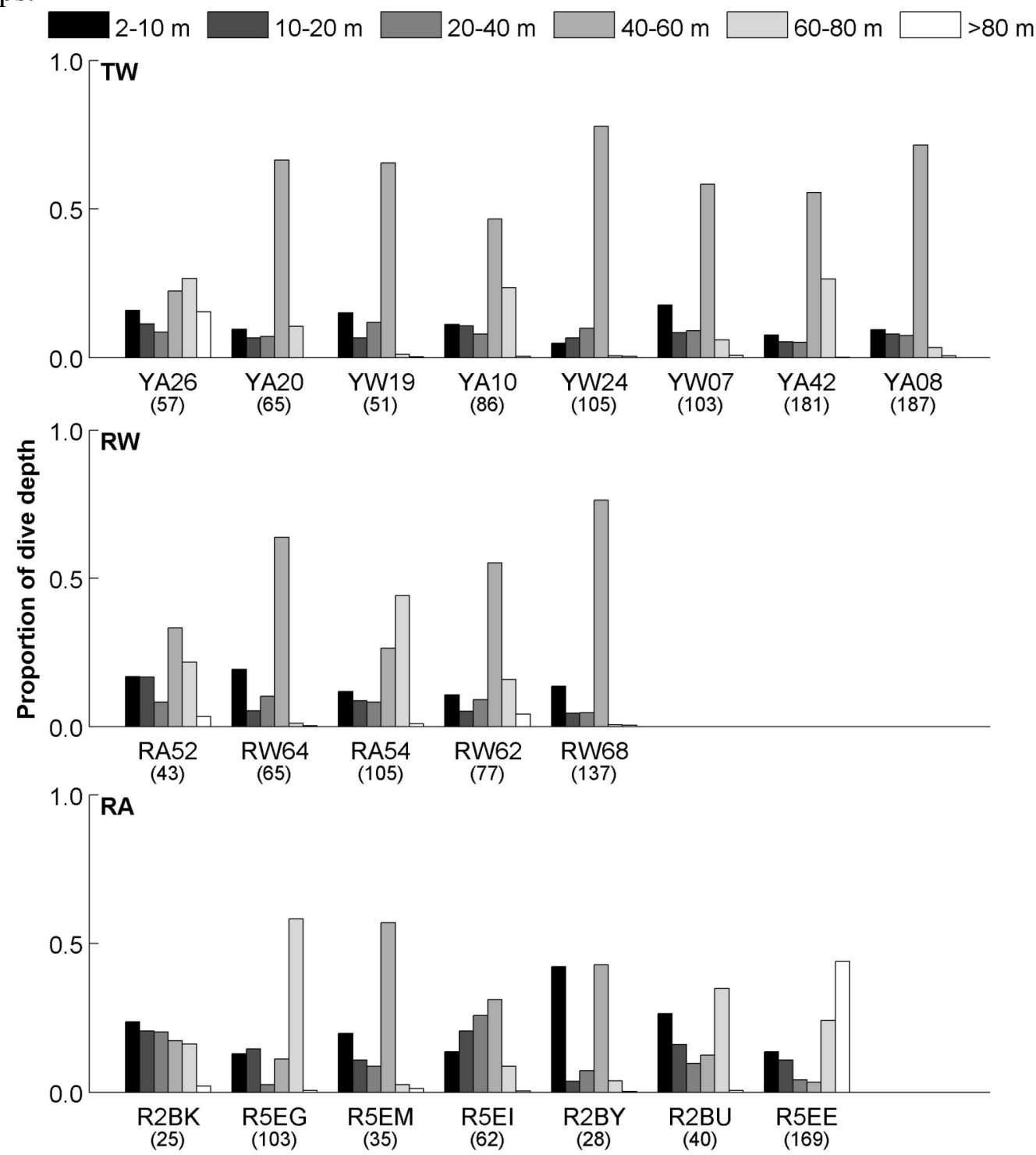
Appendix 17. TW seals' time-at-depth frequency histograms for each six-hour period. Period start times are indicated below the $\mathrm{x}$-axes, and numbers in parentheses are the number of records $(\mathrm{n})$ received during each period.

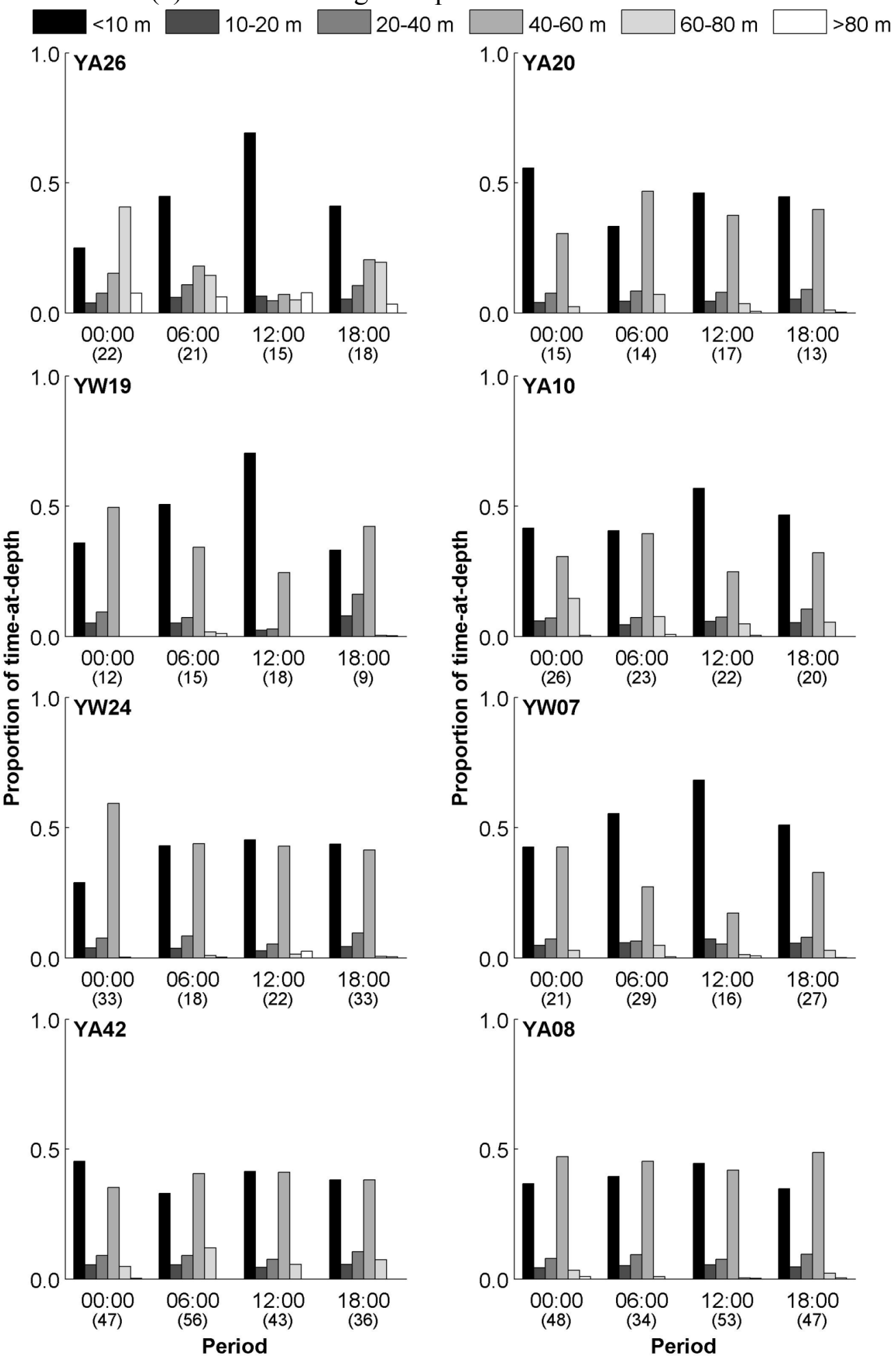


Appendix 18. RW seals' time-at-depth frequency histograms for each six-hour period. Period start times are indicated below the $\mathrm{x}$-axes, and numbers in parentheses are the number of records $(\mathrm{n})$ received during each period.

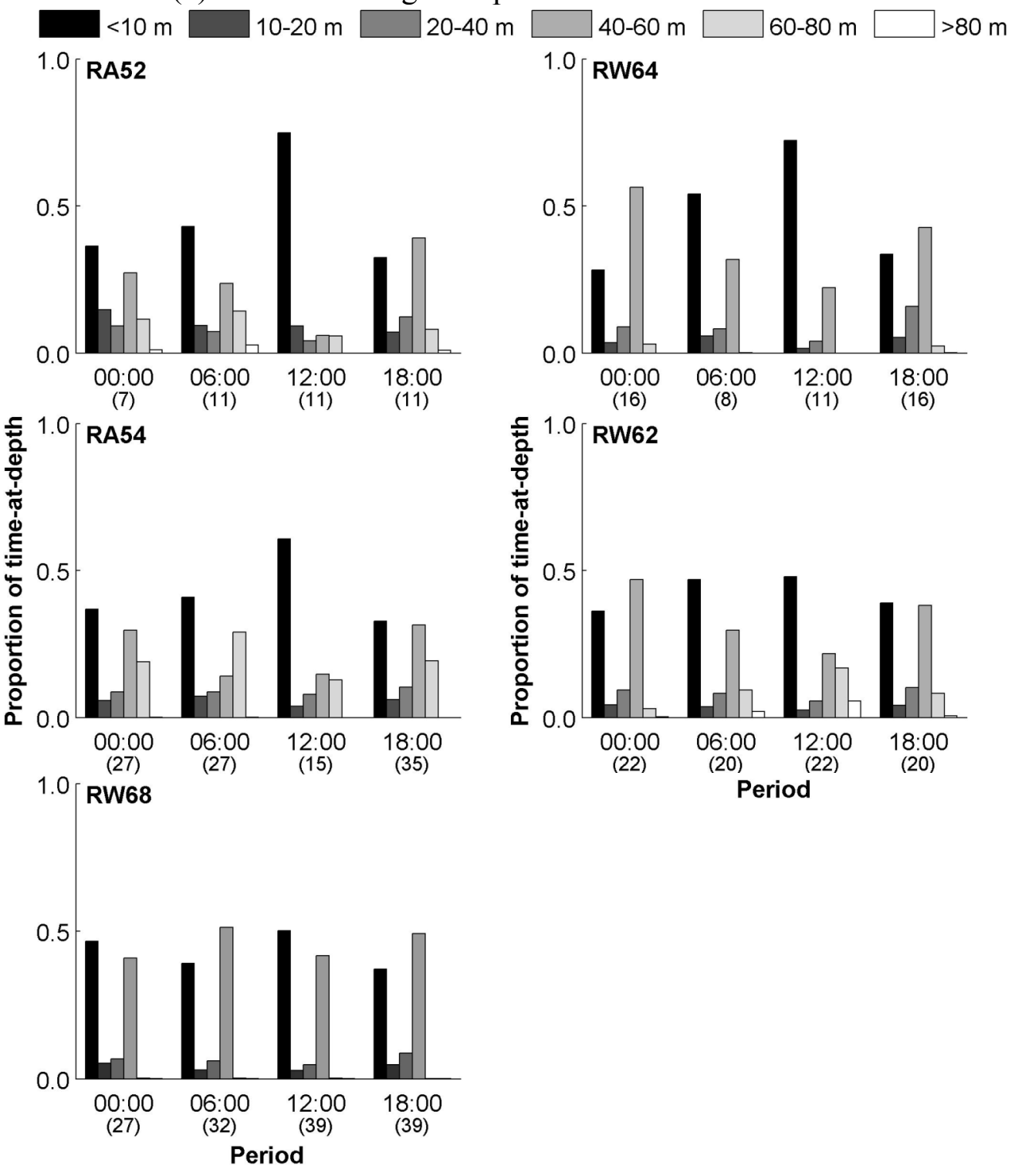


Appendix 19. RA seals' time-at-depth frequency histograms for each six-hour period. Period start times are indicated below the $\mathrm{x}$-axes, and numbers in parentheses are the number of records $(\mathrm{n})$ received during each period.

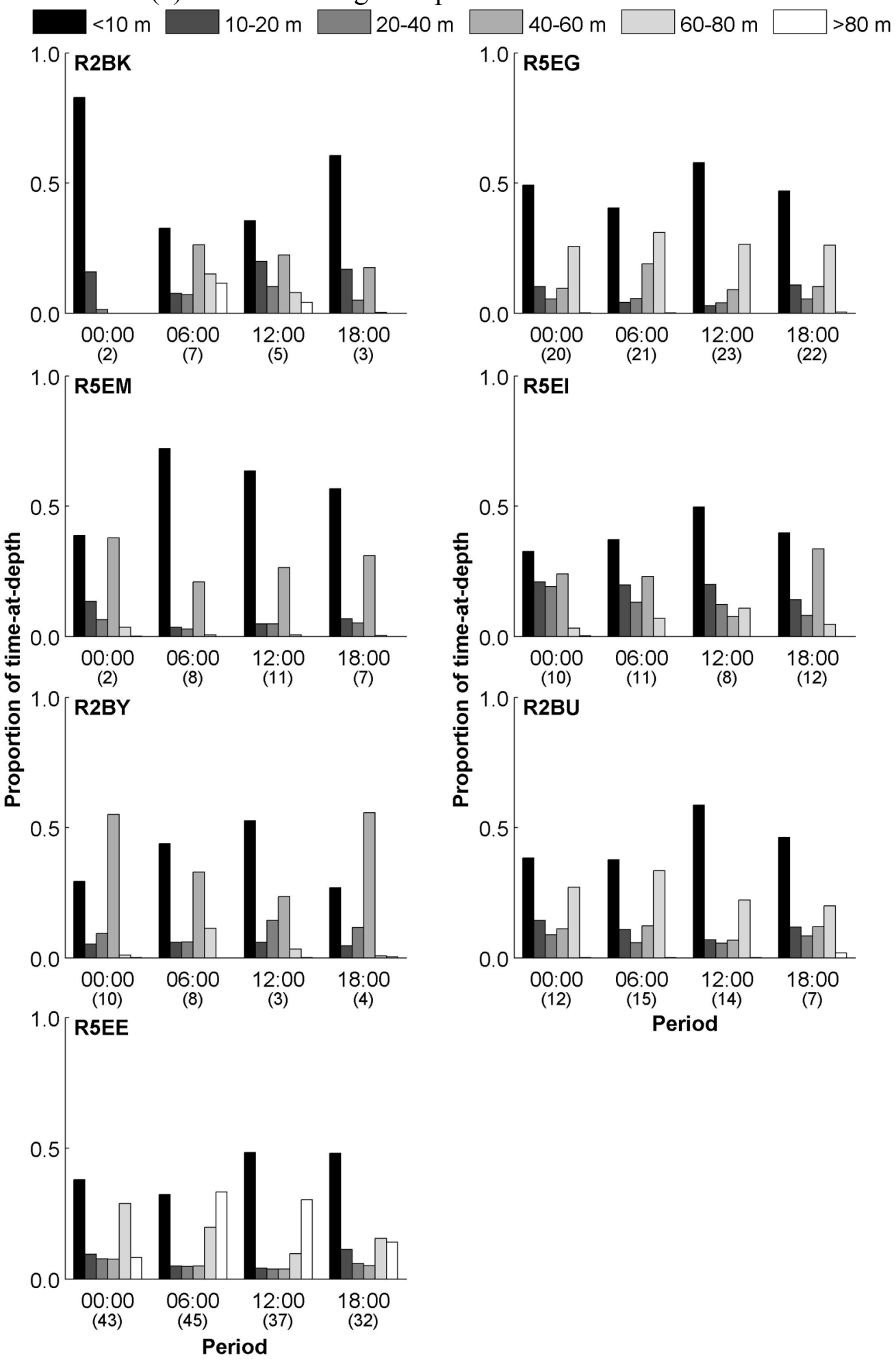


Appendix 20. Individual time-at-depth frequency histograms. Numbers in parentheses below the $\mathrm{x}$-axes are the number of records (n) received for each individual in the translocated weanling (TW), resident weanling (RW), and resident adult (RA) seal groups.

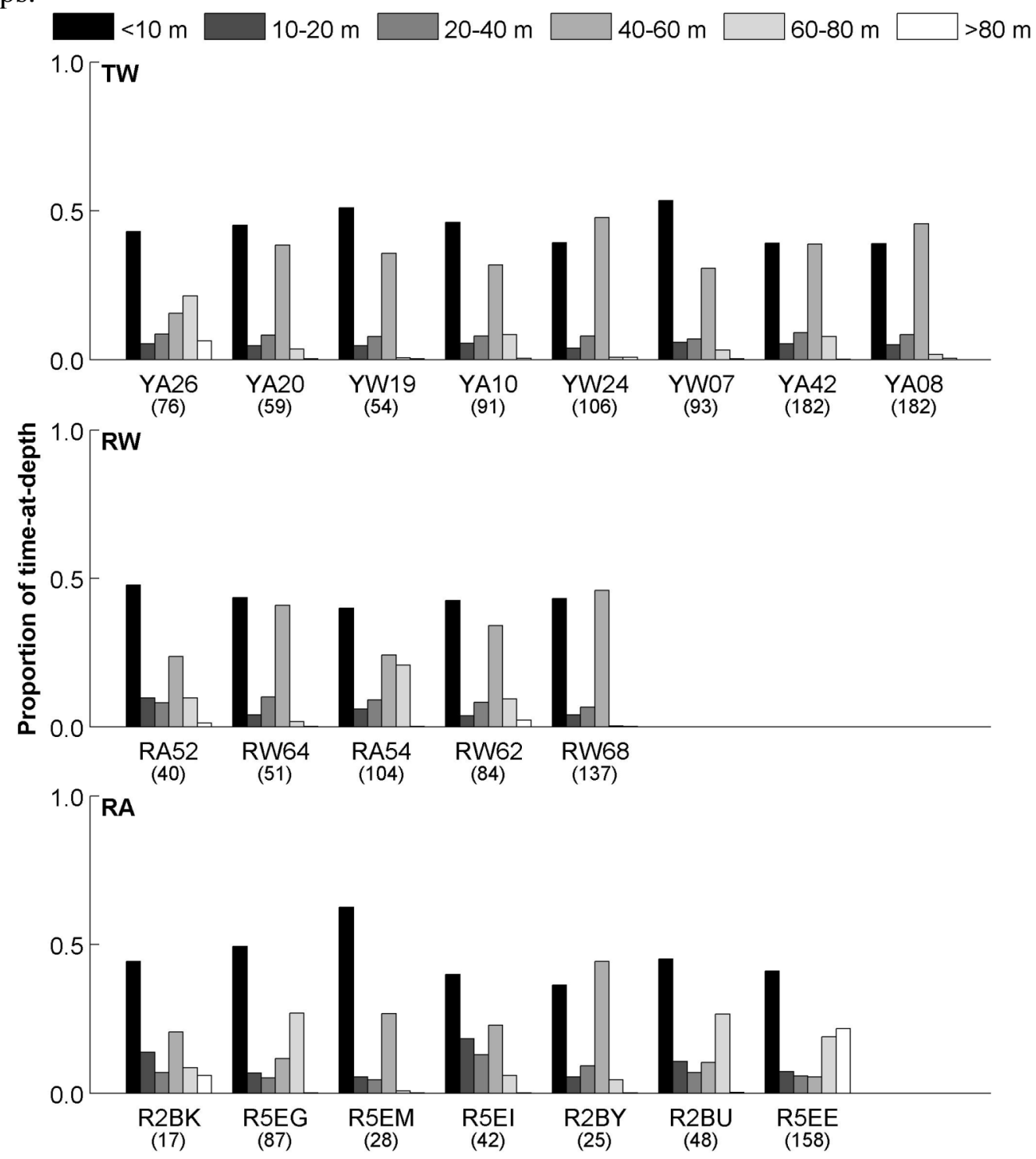


Appendix 21. TW seals' dive duration frequency histograms for each six-hour period. Period start times are indicated below the x-axes, and numbers in parentheses are the total number of dives logged during each period.

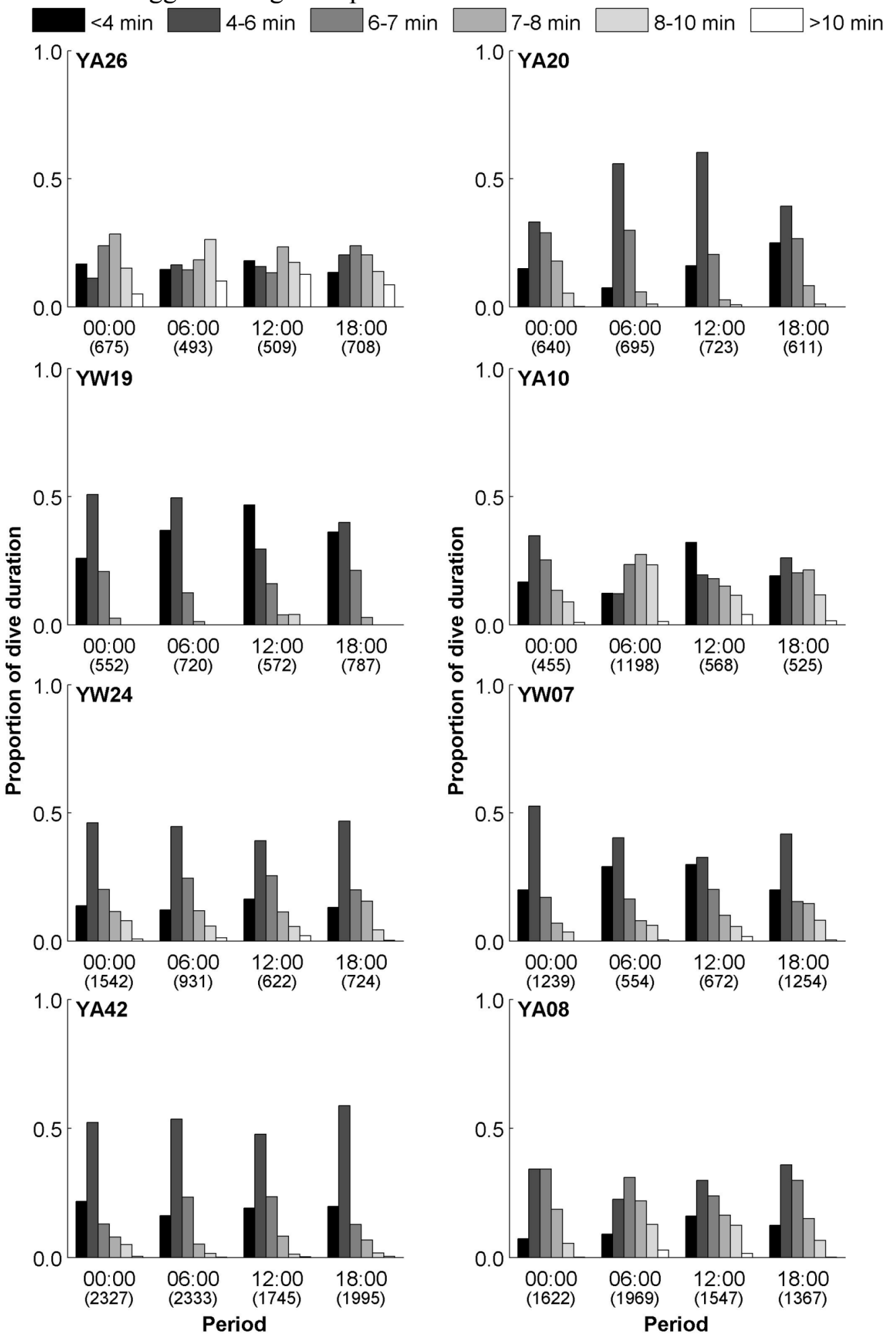


Appendix 22. RW seals' dive duration frequency histograms for each six-hour period. Period start times are indicated below the $\mathrm{x}$-axes, and numbers in parentheses are the total number of dives logged during each period.

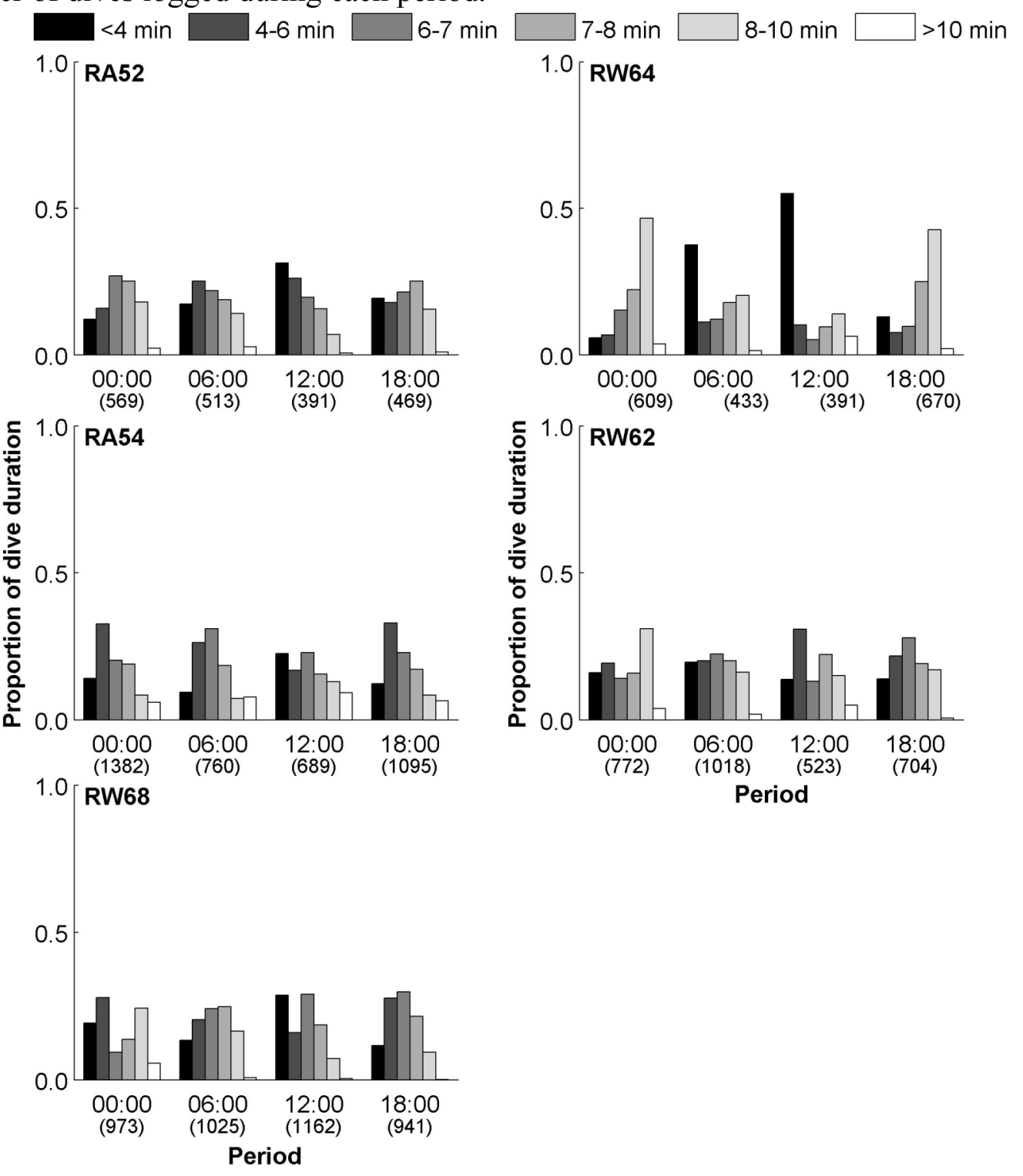


Appendix 23. RA seals' dive duration frequency histograms for each six-hour period. Period start times are indicated below the $\mathrm{x}$-axes, and numbers in parentheses are the total number of dives logged during each period.

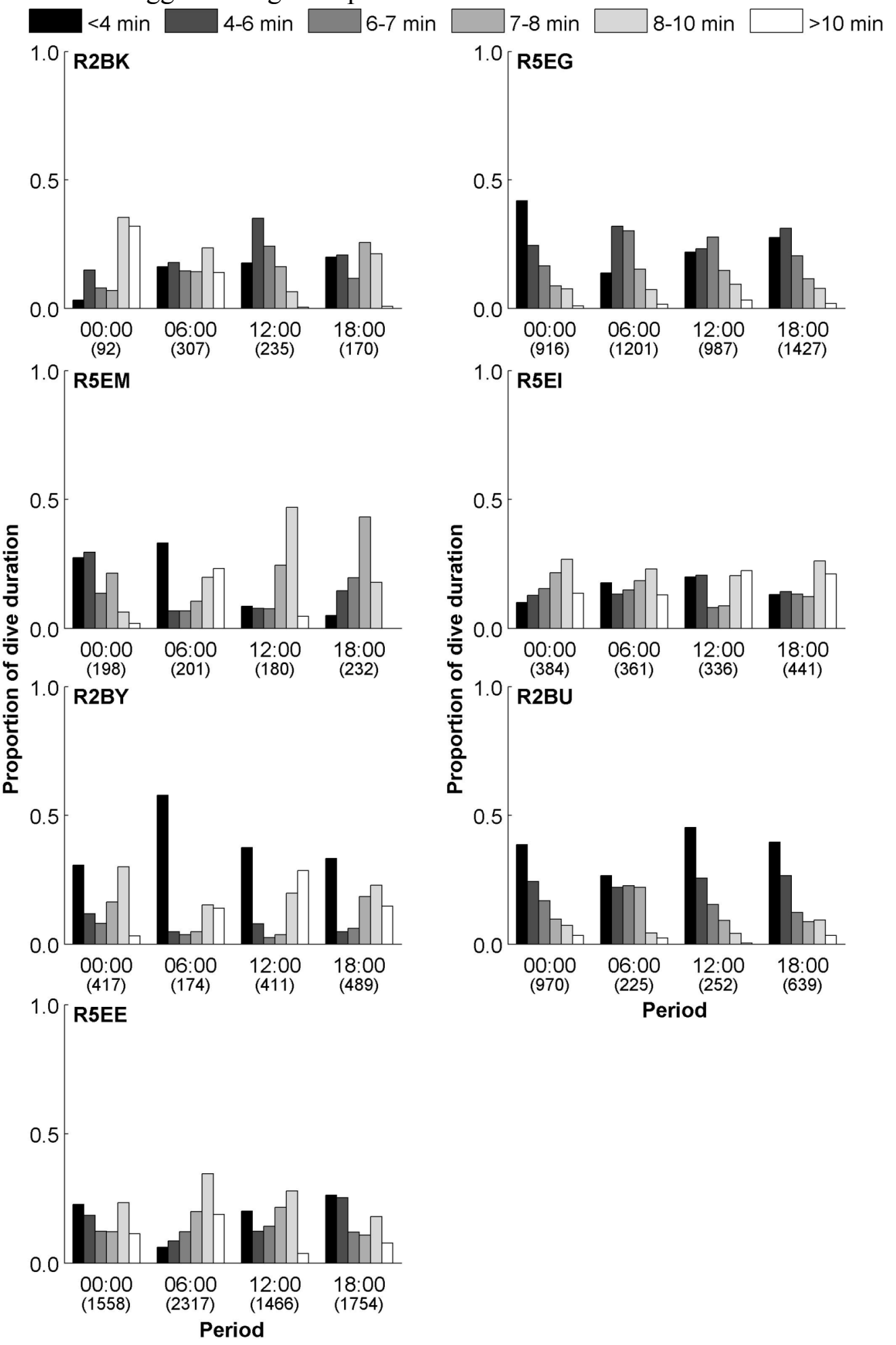


Appendix 24. Individual dive duration frequency histograms. Numbers in parentheses below the $\mathrm{x}$-axes are the number of records (n) received for each individual in the translocated weanling (TW), resident weanling (RW), and resident adult (RA) seal groups.

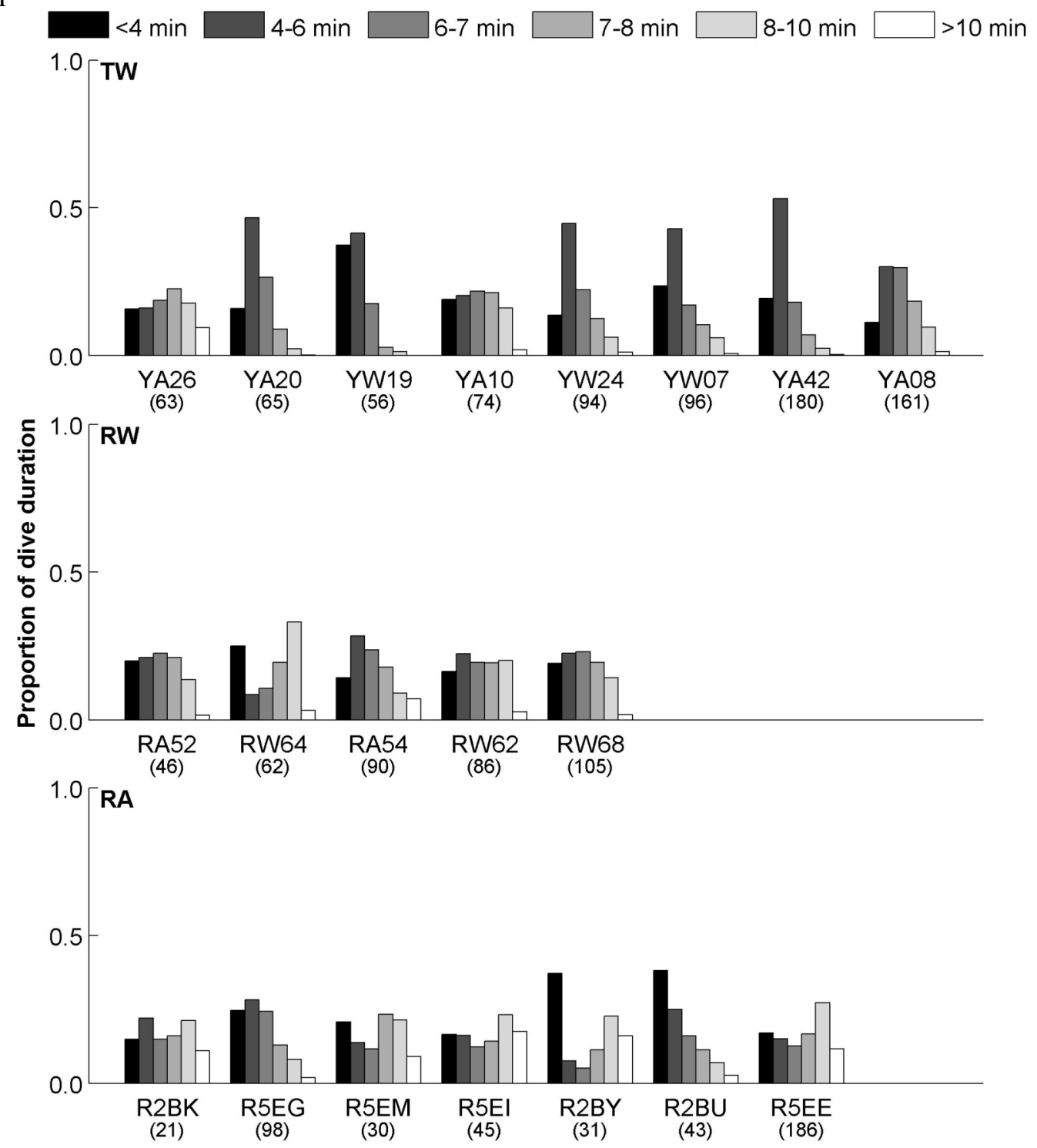


Appendix 25. Filtered Fast-GPS locations for TW seals. The yellow star marks the location of NIH, and the $200-\mathrm{m}$ isobath is indicated by the gray line.
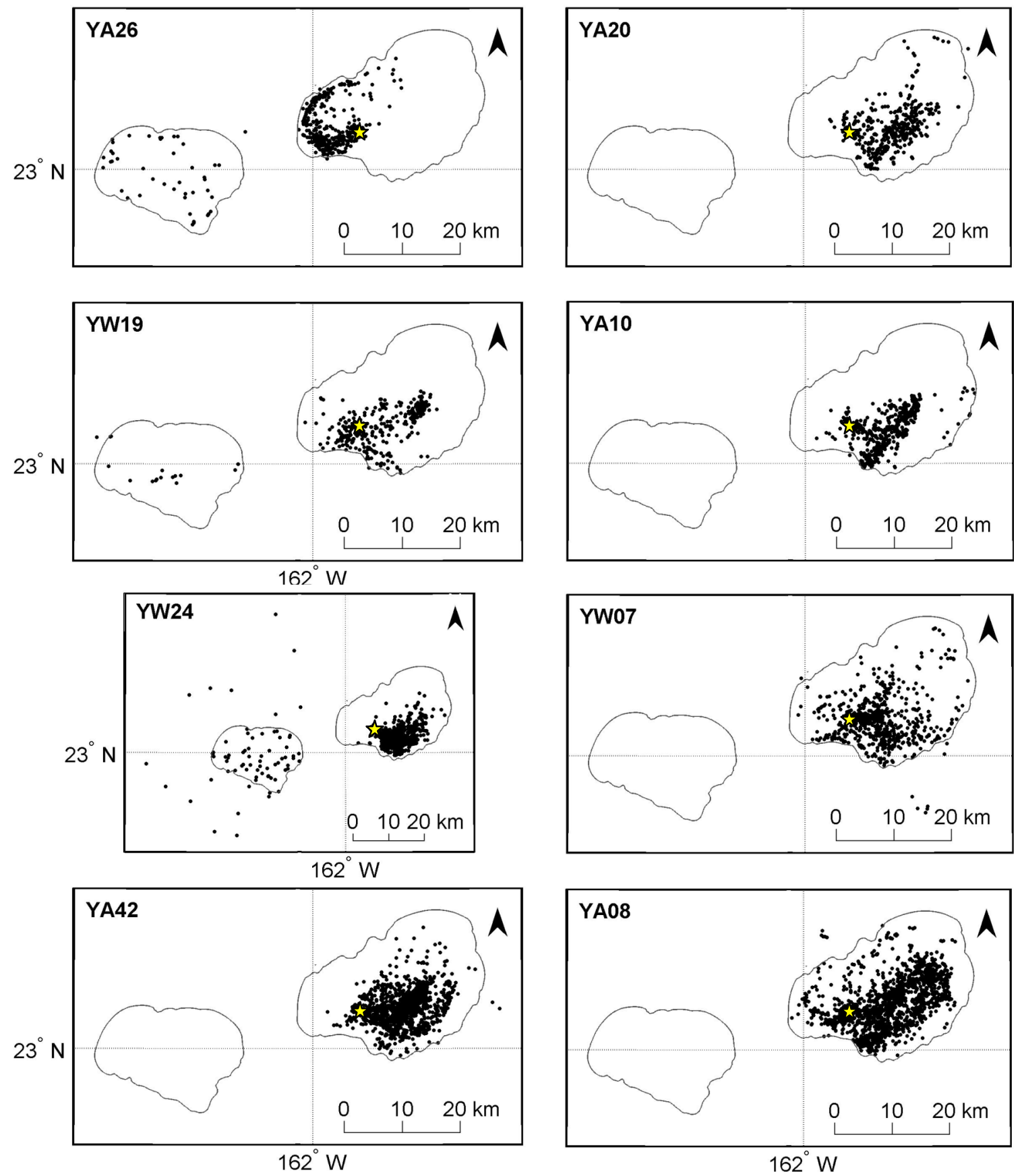
Appendix 26. Filtered Fast-GPS locations for RW seals. The yellow star marks the location of NIH, and the $200-\mathrm{m}$ isobath is indicated by the gray line.
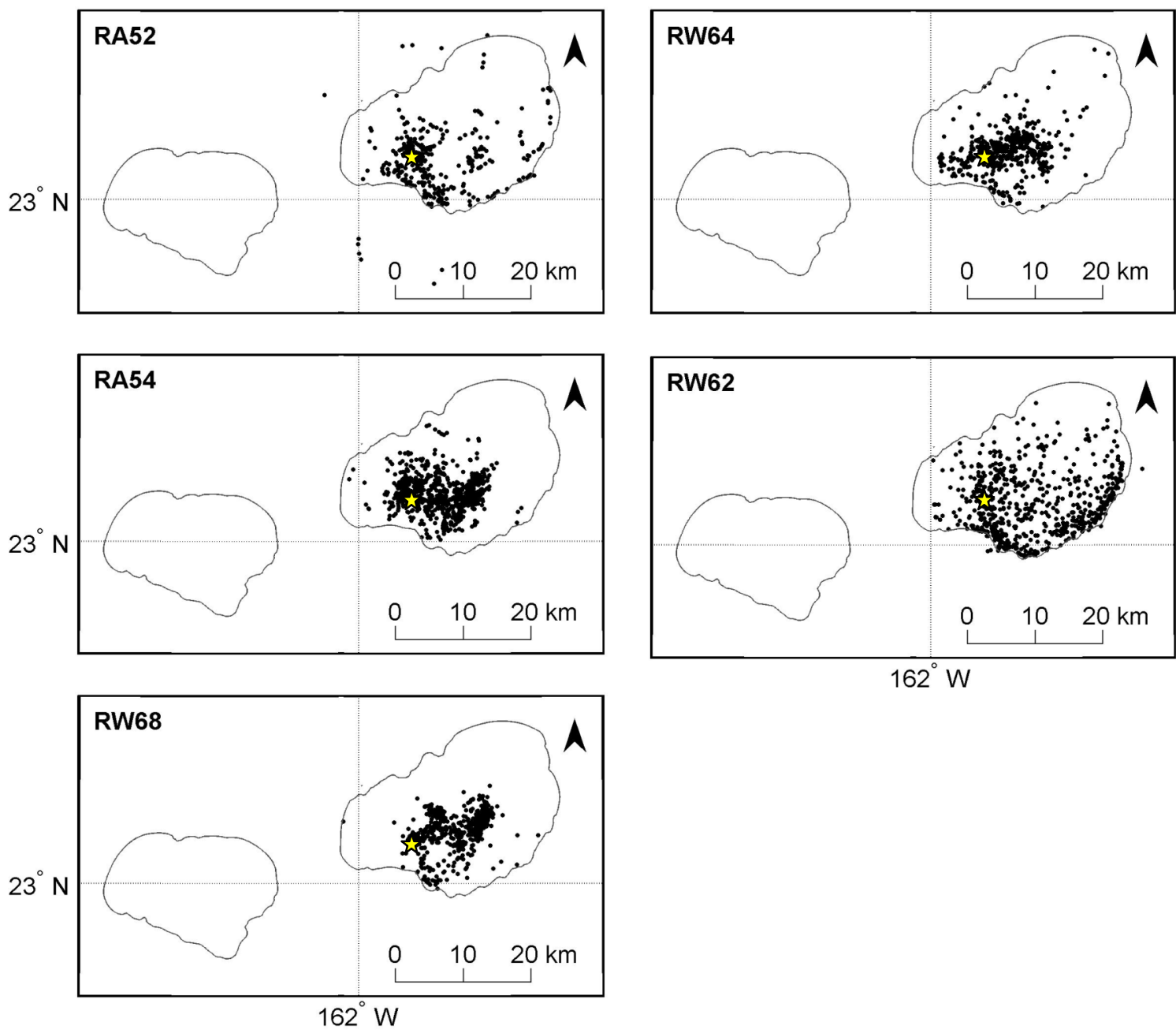
Appendix 27. Filtered Fast-GPS locations for RA seals. The yellow star marks the location of NIH, and the $200-\mathrm{m}$ isobath is indicated by the gray line.
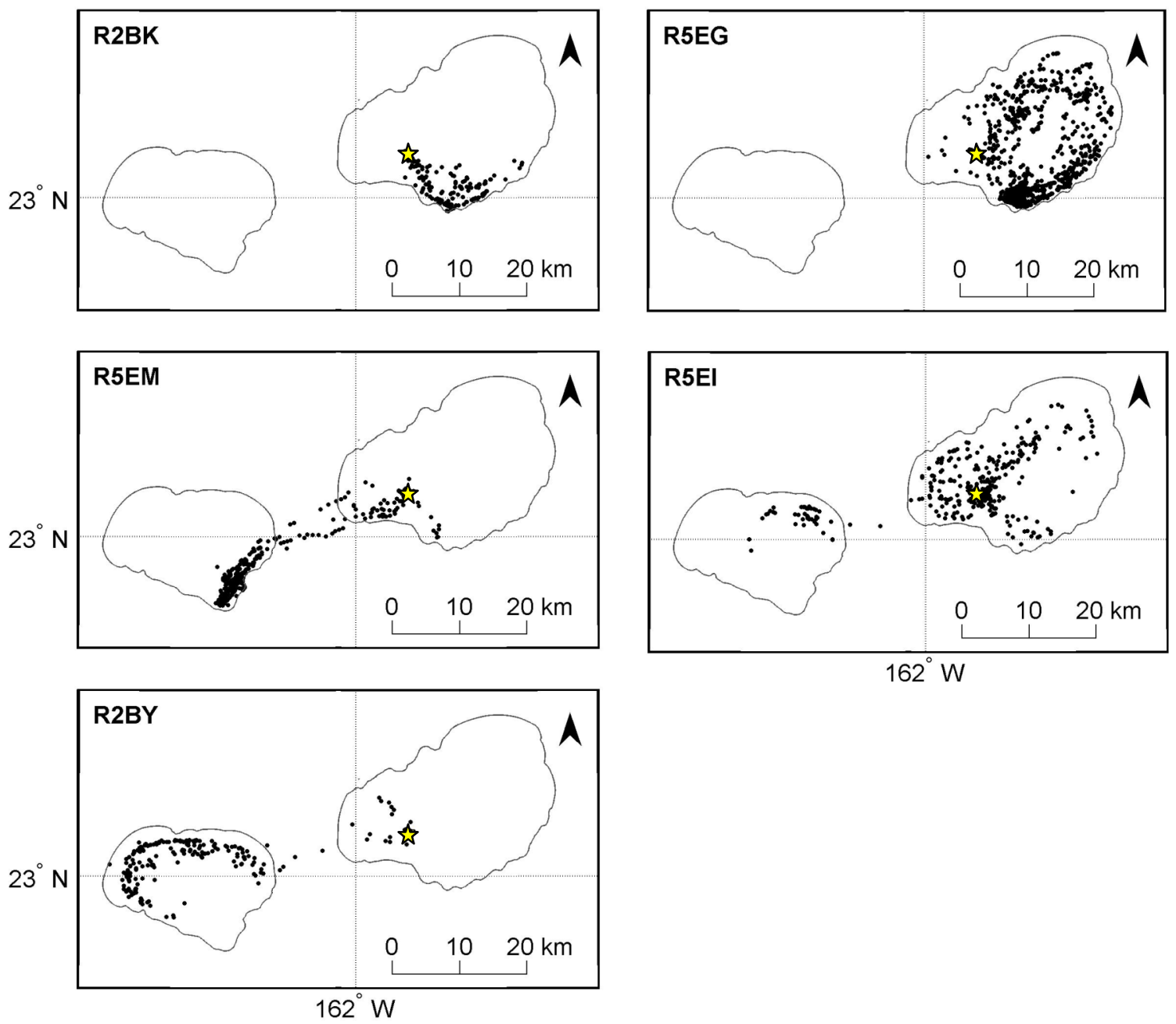
Appendix 27. Continued

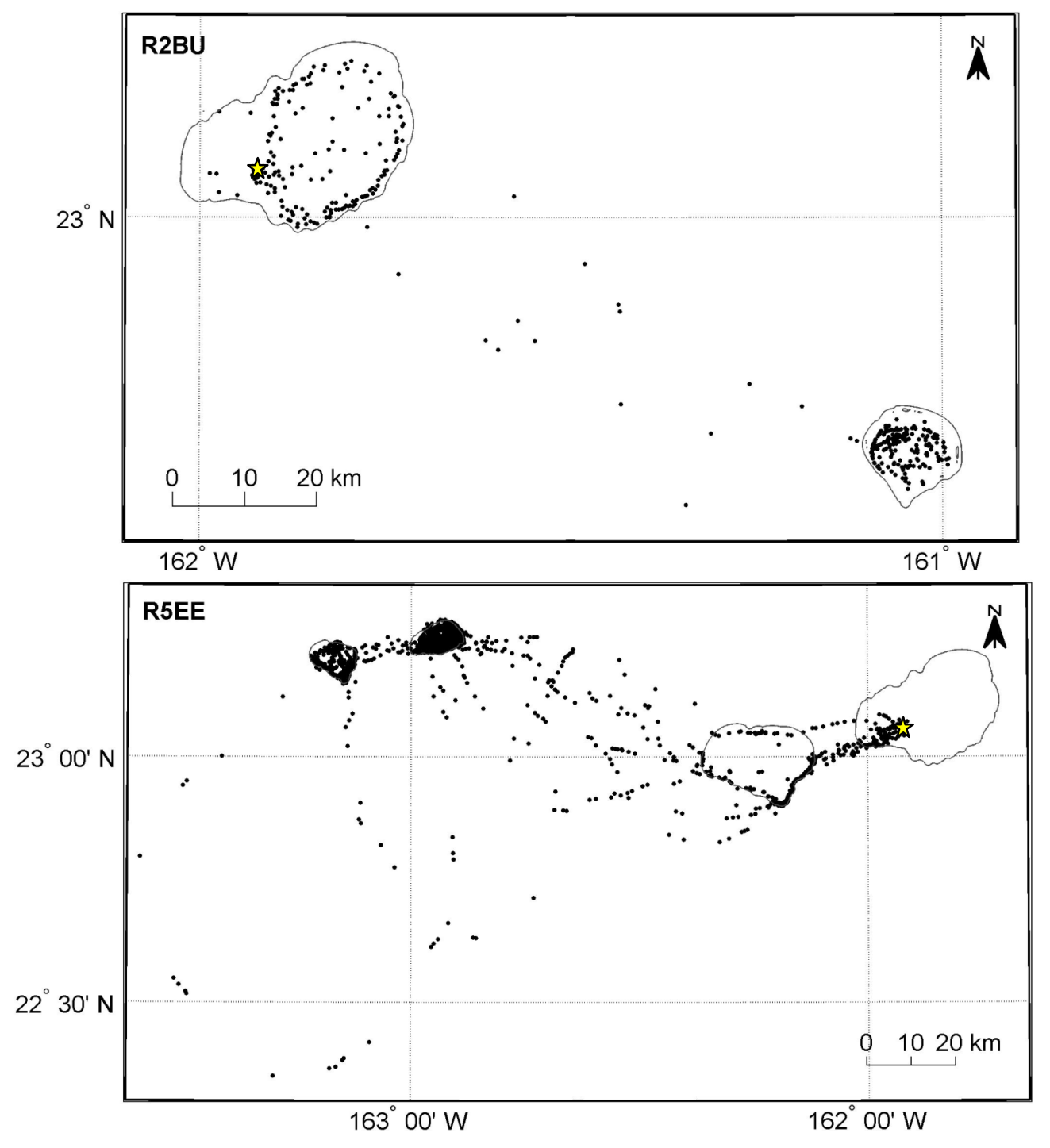


Appendix 28. Interpolated locations with two-hour sampling interval. The yellow star marks the location of $\mathrm{NIH}$, the $200-\mathrm{m}$ isobath is indicated by the gray line, $\mathrm{TW}=$ translocated weanlings, $\mathrm{RW}=$ resident weanlings, and $\mathrm{RA}=$ resident adults.
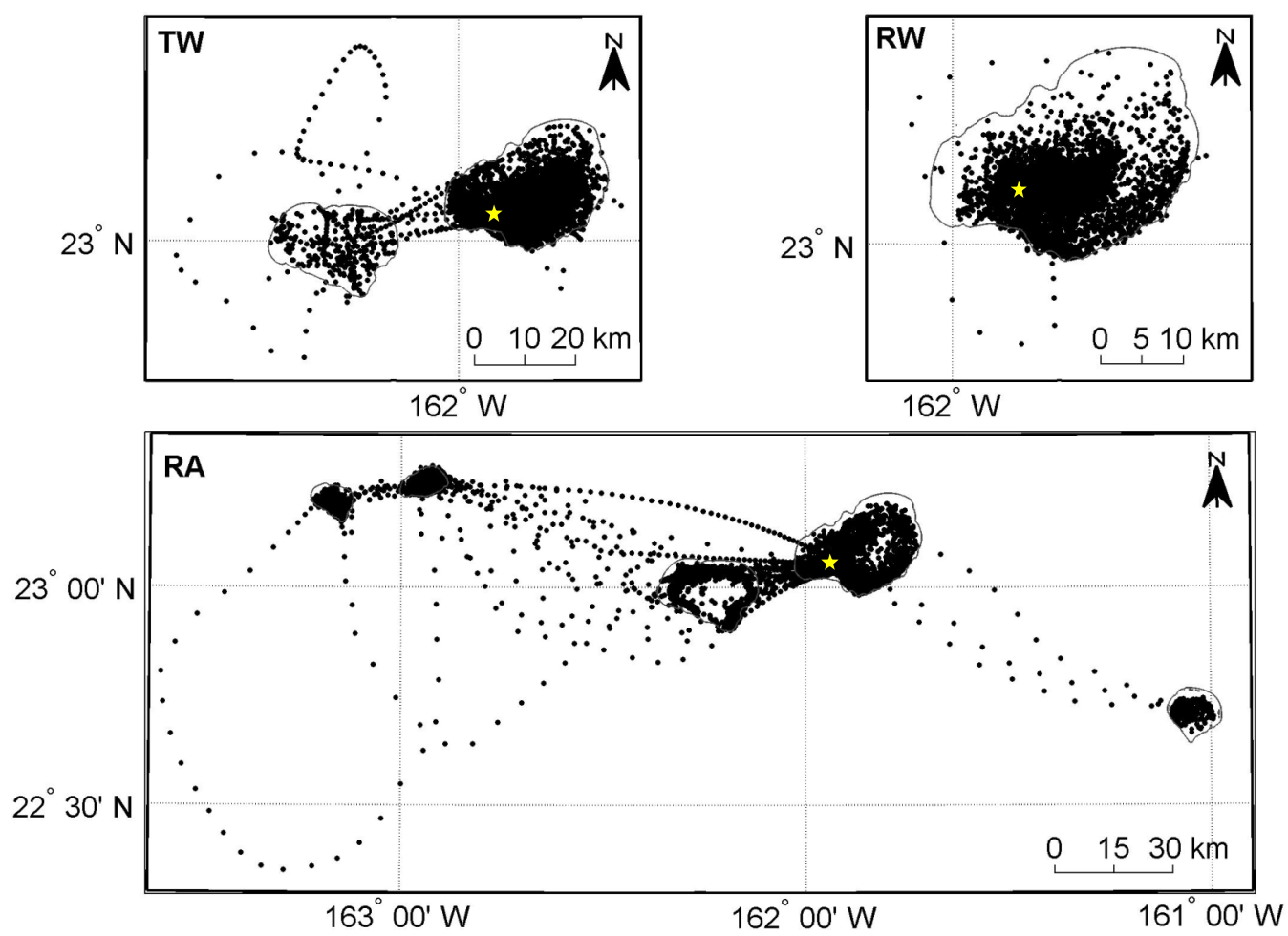
Appendix 29. Utilization distributions (UDs) for TW seals. Home ranges are the total colored area, core areas are outlined in black, red indicates areas of greatest use, and yellow represents less intensely used areas. The grid cells are $2 \mathrm{~km}^{2}$, the black star marks the location of NIH, and the 200-m isobath is indicated by the gray line.
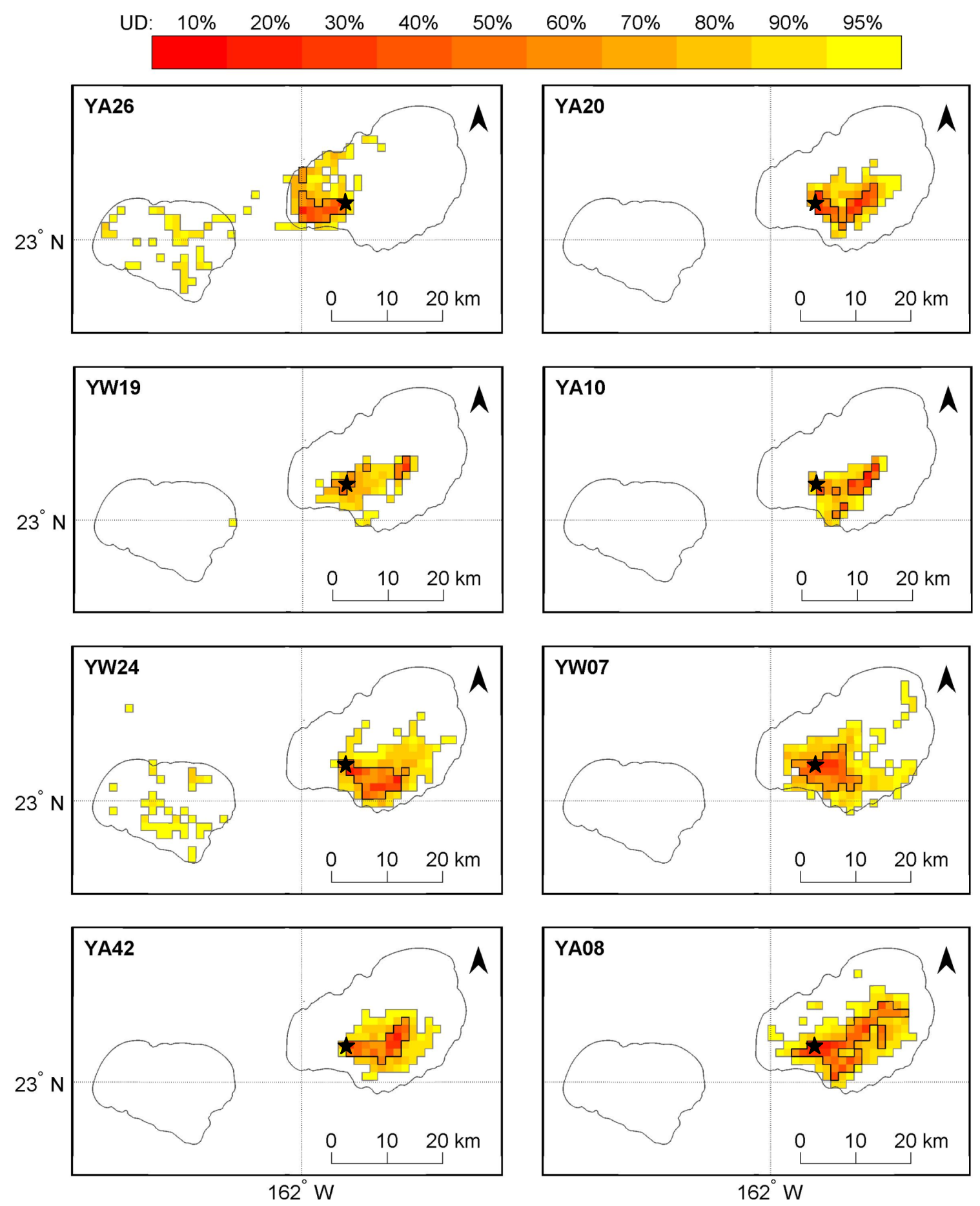
Appendix 30. Utilization distributions (UDs) for RW seals. Home ranges are the total colored area, core areas are outlined in black, red indicates areas of greatest use, and yellow represents less intensely used areas. The grid cells are $2 \mathrm{~km}^{2}$, the black star marks the location of NIH, and the 200-m isobath is indicated by the gray line.
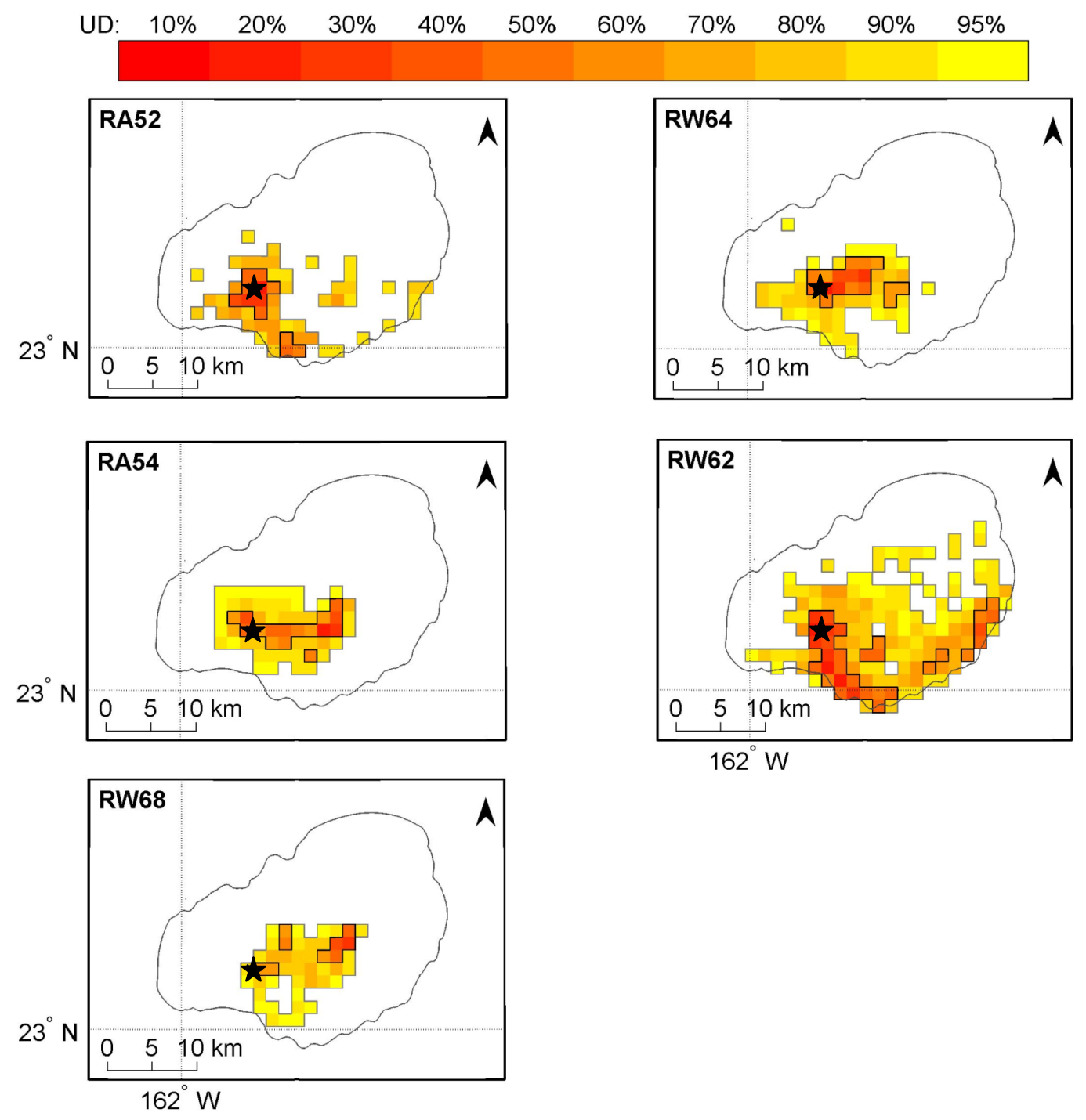
Appendix 31. Utilization distributions (UDs) for RA seals. Home ranges are the total colored area, core areas are outlined in black, red indicates areas of greatest use, and yellow represents less intensely used areas. The grid cells are $2 \mathrm{~km}^{2}$, the black star marks the location of NIH, and the 200-m isobath is indicated by the gray line.

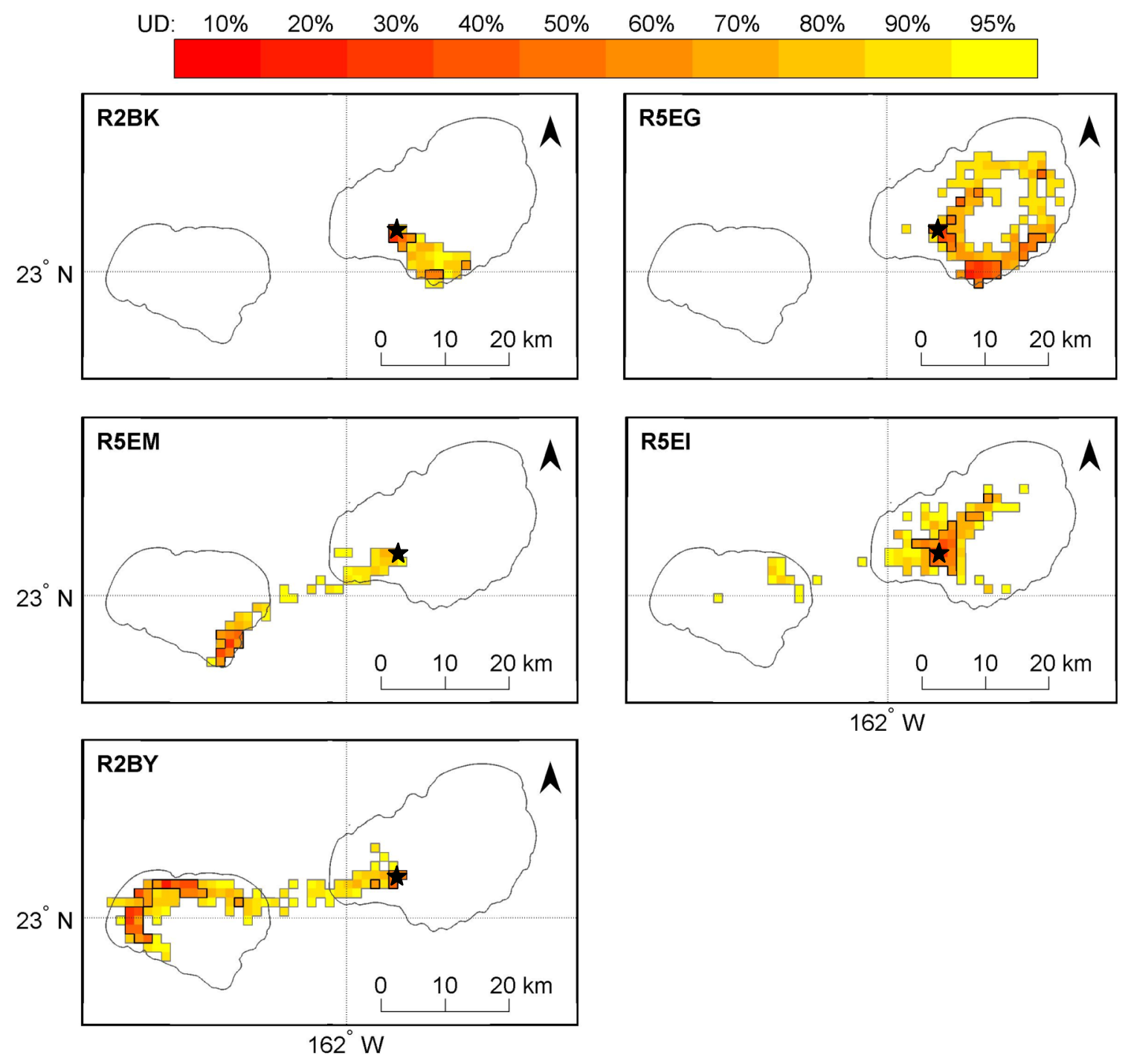


Appendix 31. Continued
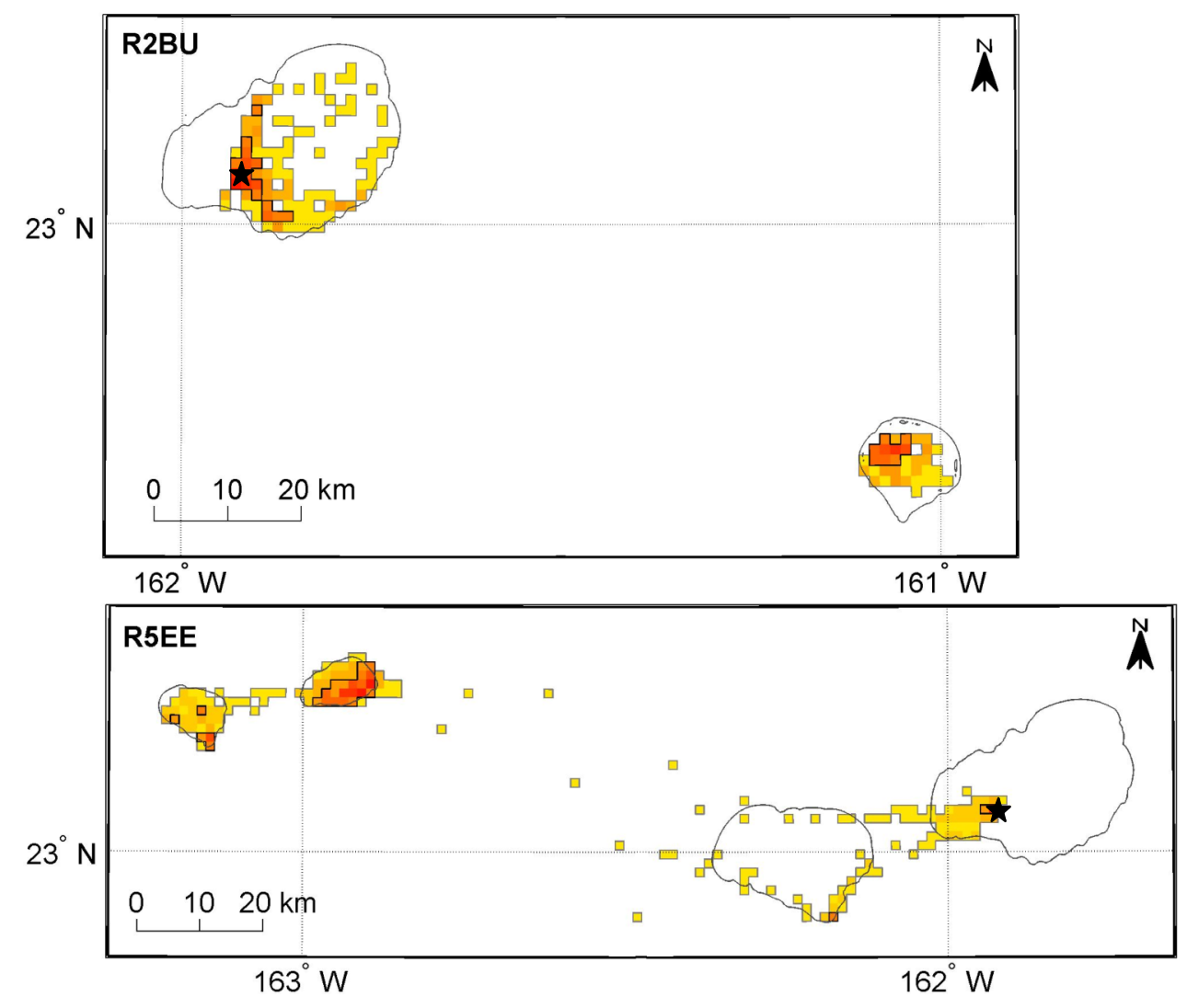
Appendix 32. Percentage utilization distribution versus percentage area plots to determine dividing point between home range core and periphery for TW seals. The best-fitting exponential curve was used, and the arrow indicates the dividing point. The portion of the curve to the left of the arrow is the core area.
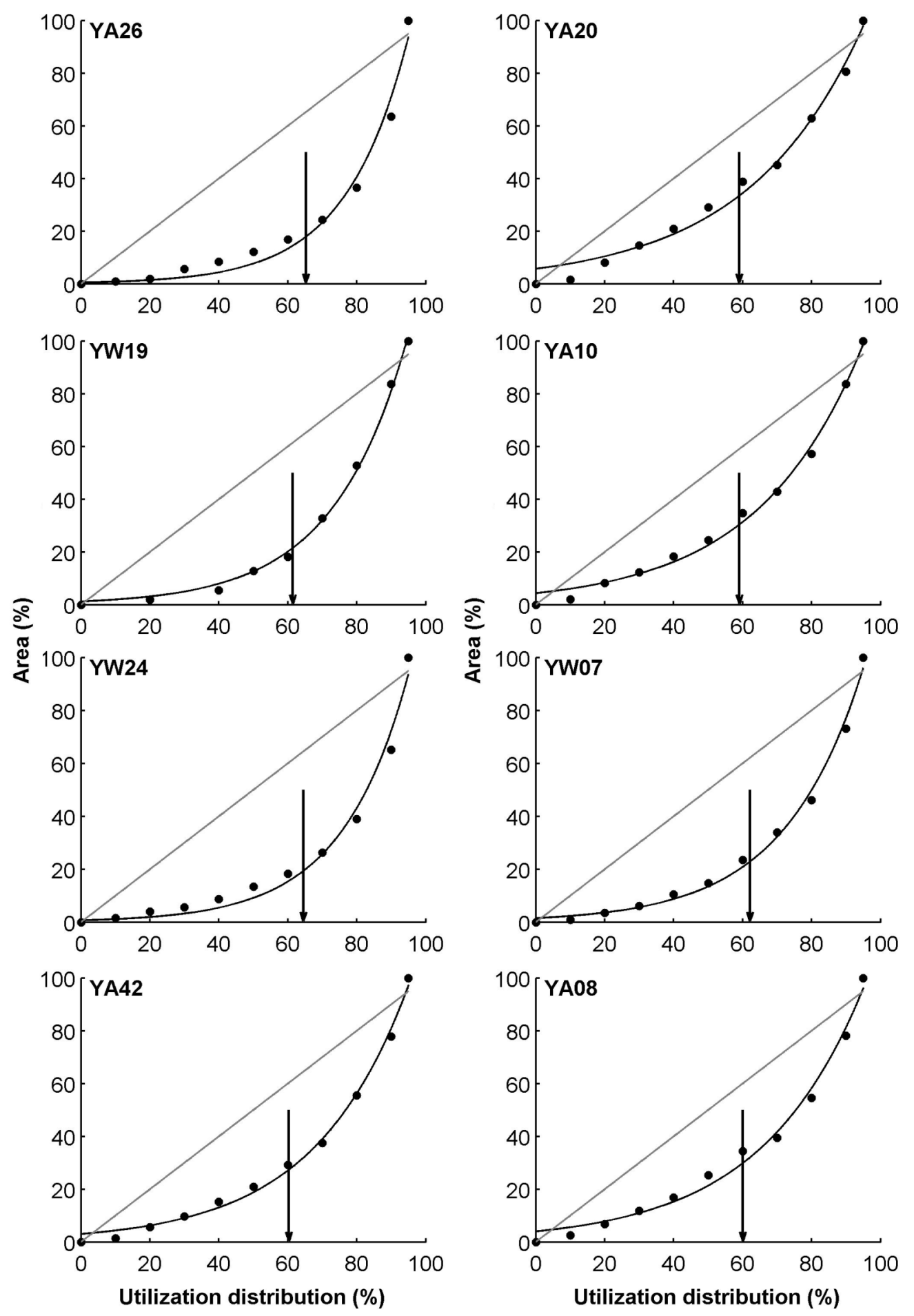
Appendix 33. Percentage utilization distribution versus percentage area plots to determine dividing point between home range core and periphery for RW seals. The best-fitting exponential curve was used, and the arrow indicates the dividing point. The portion of the curve to the left of the arrow is the core area.
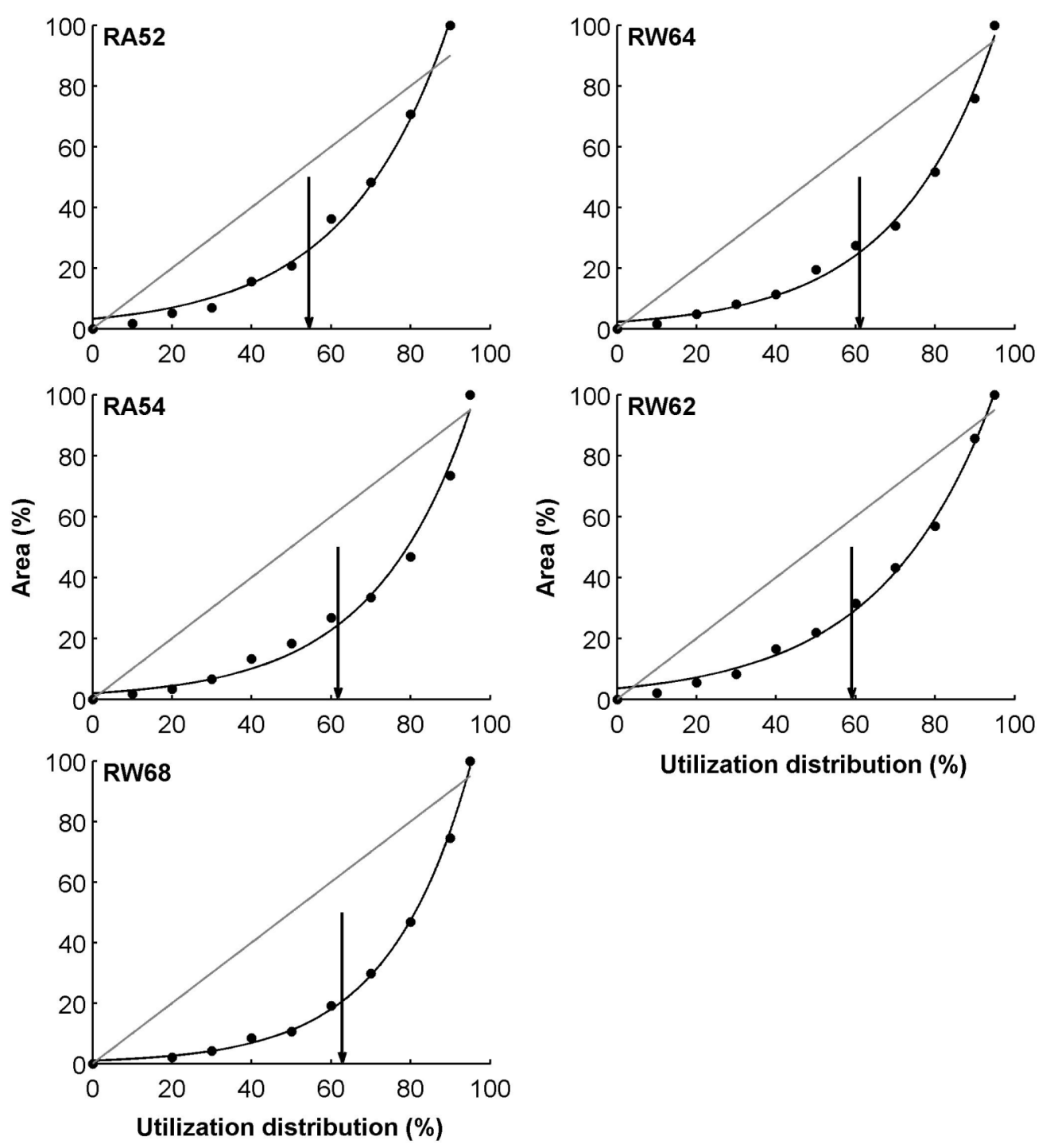
Appendix 34. Percentage utilization distribution versus percentage area plots to determine dividing point between home range core and periphery for RA seals. The bestfitting exponential curve was used, and the arrow indicates the dividing point. The portion of the curve to the left of the arrow is the core area.
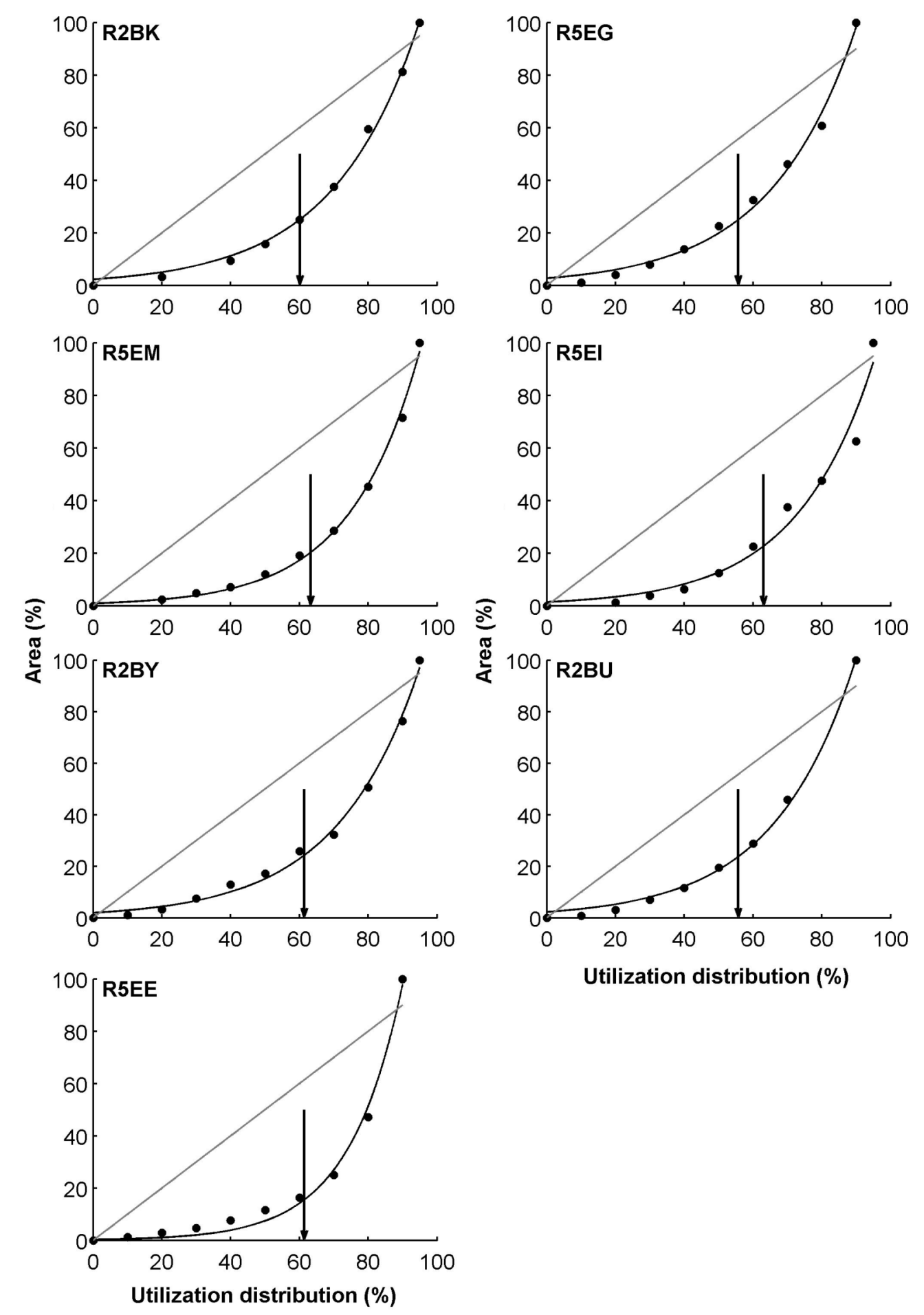

Utilization distribution (\%) 
Appendix 35. Home range (HR) and core area summary statistics for each seal.

Parameters for the exponential equation $\left(\mathrm{y}=B^{*} \mathrm{e}^{B l^{*} \mathrm{x}}\right)$ and adjusted $\mathrm{r}^{2}$ value $\left(\mathrm{r}_{\mathrm{a}}{ }^{2}\right)$ are provided for the curve of best fit for the individual percentage utilization distribution (UD) versus percentage area plot along with the range of interpolated locations per $2-\mathrm{km}^{2}$ grid cell within each individual's core area. The dividing point was rounded down to the nearest 10\% UD isopleth to separate the HR core and periphery. Core area was divided by HR area to calculate percent core area. All curve fitting statistics are for exponential clumped-use curves that were not fitted through the origin (i.e. $0 \%$ area corresponding to $0 \%$ UD). Fitting through the origin would have changed the dividing point between the HR core and periphery from the $50 \%$ to $60 \%$ UD for three seals (YA10, YA20, RW62) and from the $60 \%$ to $50 \%$ UD for R5EE.

\begin{tabular}{|c|c|c|c|c|c|c|c|c|}
\hline \multirow[b]{2}{*}{ ID } & \multirow{2}{*}{$\begin{array}{l}\text { Dividing } \\
\text { point } \\
(\% \text { UD) }\end{array}$} & \multicolumn{2}{|c|}{ Parameters } & \multirow{2}{*}{$\mathrm{r}_{\mathrm{a}}^{2}$} & \multirow{2}{*}{$\begin{array}{l}\text { Core } \\
\text { area } \\
\left(\mathrm{km}^{2}\right)\end{array}$} & \multirow{2}{*}{$\begin{array}{c}\mathrm{HR} \\
\text { area } \\
\left(\mathrm{km}^{2}\right)\end{array}$} & \multirow{2}{*}{$\begin{array}{l}\text { Percent } \\
\text { core area }\end{array}$} & \multirow{2}{*}{$\begin{array}{l}\text { Locations/cell } \\
\text { in core area }\end{array}$} \\
\hline & & $B$ & $B 1$ & & & & & \\
\hline \multicolumn{9}{|c|}{ Translocated weanlings } \\
\hline YW07 & 62.1 & 1.520 & 0.044 & 0.993 & 54 & 230 & 23.5 & $108-20$ \\
\hline YW19 & 61.5 & 1.238 & 0.046 & 0.997 & 20 & 110 & 18.2 & $185-20$ \\
\hline YW24 & 64.5 & 0.690 & 0.052 & 0.982 & 46 & 252 & 18.3 & $123-33$ \\
\hline YA08 & 60.0 & 4.003 & 0.033 & 0.989 & 82 & 238 & 34.5 & $88-24$ \\
\hline YA10 & 59.1 & 4.373 & 0.033 & 0.993 & 24 & 98 & 24.5 & $89-33$ \\
\hline YA20 & 59.0 & 5.719 & 0.030 & 0.987 & 36 & 124 & 29.0 & $39-19$ \\
\hline YA26 & 65.3 & 0.472 & 0.056 & 0.981 & 36 & 214 & 16.8 & $63-20$ \\
\hline YA42 & 60.3 & 3.022 & 0.037 & 0.995 & 42 & 144 & 29.2 & $200-42$ \\
\hline \multicolumn{9}{|c|}{ Resident weanlings } \\
\hline RW62 & 59.1 & 3.547 & 0.035 & 0.995 & 64 & 292 & 21.9 & $49-14$ \\
\hline RW64 & 61.1 & 2.236 & 0.040 & 0.994 & 34 & 124 & 27.4 & $71-22$ \\
\hline RW68 & 62.8 & 0.980 & 0.048 & 0.998 & 18 & 94 & 19.2 & $378-57$ \\
\hline RA52 & 54.5 & 3.235 & 0.038 & 0.994 & 24 & 116 & 20.7 & $32-8$ \\
\hline RA54 & 61.8 & 1.945 & 0.041 & 0.988 & 32 & 120 & 26.7 & $129-31$ \\
\hline \multicolumn{9}{|c|}{ Resident adults } \\
\hline $\mathrm{R} 2 \mathrm{BK}$ & 60.1 & 2.273 & 0.040 & 0.996 & 16 & 64 & 25.0 & $85-12$ \\
\hline $\mathrm{R} 2 \mathrm{BU}$ & 55.7 & 2.260 & 0.042 & 0.997 & 50 & 258 & 19.4 & $54-8$ \\
\hline R2BY & 61.4 & 1.922 & 0.041 & 0.994 & 48 & 186 & 25.8 & $40-11$ \\
\hline R5EE & 61.4 & 0.296 & 0.064 & 0.991 & 56 & 344 & 16.3 & $147-26$ \\
\hline R5EG & 55.7 & 2.692 & 0.040 & 0.992 & 46 & 204 & 22.6 & $82-12$ \\
\hline R5EI & 63.1 & 1.412 & 0.044 & 0.970 & 36 & 160 & 22.5 & $87-7$ \\
\hline R5EM & 63.3 & 0.900 & 0.049 & 0.996 & 16 & 84 & 19.1 & $63-15$ \\
\hline
\end{tabular}


Appendix 36. Percentage utilization distribution versus percentage area plots to determine dividing point between home range core and periphery for each group. The best-fitting exponential curve was used, and the arrow indicates the dividing point. The portion of the curve to the left of the arrow is the core area. The exponential equation and adjusted $\mathrm{r}^{2}$ value $\left(\mathrm{r}_{\mathrm{a}}{ }^{2}\right)$ are provided for the curve of best fit. TW $=$ translocated weanlings, $\mathrm{RW}=$ resident weanlings, $\mathrm{RA}=$ resident adults, and $\mathrm{All}=$ all seals combined.
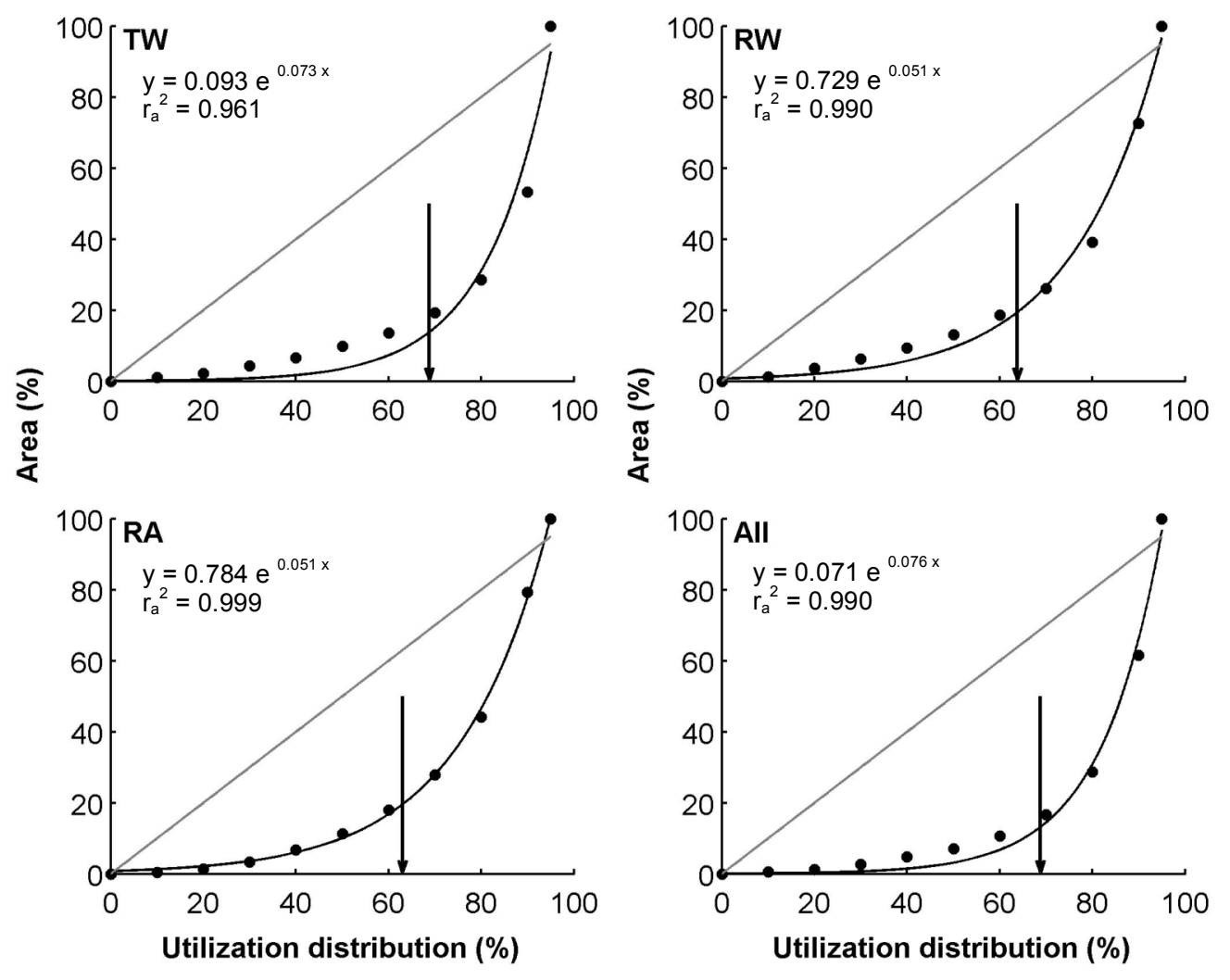
Appendix 37. Foraging trip statistics for each individual. Means \pm standard deviations were calculated for maximum trip distance, total trip distance, relative search index, trip duration, and trip direction.

\begin{tabular}{|c|c|c|c|c|c|c|}
\hline ID & $\begin{array}{c}\text { Maximum } \\
\text { distance }(\mathrm{km})\end{array}$ & $\begin{array}{l}\text { Total distance } \\
\qquad(\mathrm{km})\end{array}$ & $\begin{array}{c}\text { Relative } \\
\text { search index }\end{array}$ & $\begin{array}{l}\text { Duration } \\
\text { (d) }\end{array}$ & $\begin{array}{l}\text { Direction } \\
\text { (deg) }\end{array}$ & $\begin{array}{c}\# \\
\text { trips }\end{array}$ \\
\hline \multicolumn{7}{|c|}{ Translocated weanlings } \\
\hline YW07 & $8.7 \pm 5.2$ & $29.5 \pm 27.4$ & $3.1 \pm 1.2$ & $2.1 \pm 1.8$ & $119.2 \pm 67.9$ & 80 \\
\hline YW19 & $8.1 \pm 6.5$ & $22.3 \pm 20.1$ & $2.6 \pm 0.7$ & $1.6 \pm 1.3$ & $142.5 \pm 89.2$ & 56 \\
\hline YW24 & $11.3 \pm 7.4$ & $37.9 \pm 62.3$ & $2.9 \pm 1.1$ & $2.8 \pm 2.7$ & $109.4 \pm 32.5$ & 67 \\
\hline YA08 & $11.4 \pm 5.9$ & $53.4 \pm 49.9$ & $4.1 \pm 2.3$ & $3.6 \pm 3.4$ & $114.2 \pm 79.8$ & 64 \\
\hline YA10 & $9.9 \pm 3.8$ & $41.6 \pm 33.3$ & $3.8 \pm 1.9$ & $3.5 \pm 3.1$ & $112.5 \pm 64.3$ & 30 \\
\hline YA20 & $11.3 \pm 5.6$ & $49.1 \pm 35.7$ & $4.0 \pm 1.9$ & $4.5 \pm 3.0$ & $91.4 \pm 68.5$ & 18 \\
\hline YA26 & $10.4 \pm 9.8$ & $38.8 \pm 46.0$ & $3.4 \pm 1.6$ & $3.2 \pm 3.1$ & $253.2 \pm 49.0$ & 31 \\
\hline YA42 & $12.2 \pm 4.6$ & $52.2 \pm 33.6$ & $4.1 \pm 2.0$ & $3.4 \pm 2.7$ & $90.5 \pm 35.0$ & 65 \\
\hline \multicolumn{7}{|c|}{ Resident weanlings } \\
\hline RW62 & $13.0 \pm 6.5$ & $42.8 \pm 30.3$ & $3.1 \pm 1.1$ & $2.4 \pm 1.6$ & $122.8 \pm 76.4$ & 58 \\
\hline RW64 & $7.6 \pm 3.6$ & $25.1 \pm 17.7$ & $3.1 \pm 1.2$ & $1.9 \pm 1.4$ & $123.0 \pm 81.3$ & 54 \\
\hline RW68 & $10.0 \pm 3.2$ & $34.0 \pm 20.0$ & $3.2 \pm 1.3$ & $3.1 \pm 2.4$ & $70.0 \pm 26.2$ & 68 \\
\hline RA52 & $8.3 \pm 6.3$ & $31.6 \pm 30.0$ & $3.5 \pm 1.1$ & $2.0 \pm 1.4$ & $146.6 \pm 91.2$ & 18 \\
\hline RA54 & $7.9 \pm 3.3$ & $43.9 \pm 47.4$ & $5.1 \pm 3.3$ & $3.4 \pm 4.3$ & $138.0 \pm 103.6$ & 36 \\
\hline \multicolumn{7}{|c|}{ Resident adults } \\
\hline $\mathrm{R} 2 \mathrm{BK}$ & $10.6 \pm 4.3$ & $31.0 \pm 19.4$ & $2.8 \pm 1.0$ & $1.8 \pm 1.0$ & $122.7 \pm 16.3$ & 23 \\
\hline $\mathrm{R} 2 \mathrm{BU}$ & $15.5 \pm 16.3$ & $44.2 \pm 78.6$ & $2.5 \pm 0.6$ & $1.8 \pm 2.9$ & $87.1 \pm 56.1$ & 36 \\
\hline $\mathrm{R} 2 \mathrm{BY}$ & $28.3 \pm 19.5$ & $116.5 \pm 124.9$ & $3.4 \pm 2.2$ & $8.3 \pm 8.4$ & $266.4 \pm 42.5$ & 8 \\
\hline R5EE & $89.8 \pm 57.1$ & $337.5 \pm 232.2$ & $3.3 \pm 0.9$ & $14.4 \pm 10.1$ & $268.6 \pm 18.7$ & 14 \\
\hline R5EG & $16.0 \pm 5.2$ & $77.5 \pm 40.8$ & $4.7 \pm 2.0$ & $4.7 \pm 2.9$ & $65.3 \pm 24.7$ & 20 \\
\hline R5EI & $5.8 \pm 5.8$ & $14.4 \pm 15.7$ & $2.4 \pm 0.7$ & $0.8 \pm 0.7$ & $143.9 \pm 111.9$ & 71 \\
\hline R5EM & $18.3 \pm 15.2$ & $59.8 \pm 51.4$ & $3.0 \pm 0.8$ & $3.7 \pm 3.1$ & $205.0 \pm 84.6$ & 8 \\
\hline
\end{tabular}


Appendix 38. Habitat classifications for 28 camera drop sites on NIH terrace. Induration (Ind) was either hard-bottom (HB) or unconsolidated (UN). Roughness (Rough) was classified as none, low, moderate (mod), or high. Live coral and macroalgal cover could not be determined for sites (--) with severe camera kiting above the seafloor. Dense heart urchin aggregations and large features were categorized as present (P) or absent (A). Distance and direction to NIH were calculated from the start drift coordinates to island center. Site 26 was surveyed twice (18 Nov 2010 and 19 Aug 2011), and on both dates the habitat classifications were identical. Loose rubble or talus also may have been present at sites $5,7,9,11,16$, and 19 .

\begin{tabular}{|c|c|c|c|c|c|c|c|c|c|}
\hline Site & Ind & Rough & $\begin{array}{l}\text { Coral } \\
\text { cover }\end{array}$ & $\begin{array}{l}\text { Algal } \\
\text { cover }\end{array}$ & Urchins & Features & $\begin{array}{c}\text { Depth } \\
(\mathrm{m})\end{array}$ & $\begin{array}{c}\text { Distance } \\
(\mathrm{km})\end{array}$ & $\begin{array}{c}\text { Direction } \\
\text { (deg) }\end{array}$ \\
\hline 1 & $\mathrm{HB}$ & high & $\leq 10 \%$ & $\bmod$ & A & $\mathrm{P}$ & 34.0 & 1.14 & 168.9 \\
\hline 2 & $\mathrm{HB}$ & $\bmod$ & -- & -- & A & $\mathrm{P}$ & 32.3 & 1.29 & 255.5 \\
\hline 3 & $\mathrm{HB}$ & $\bmod$ & -- & -- & A & A & 37.0 & 2.59 & 261.5 \\
\hline 4 & UN & none & none & none & $\mathrm{P}$ & A & 45.8 & 5.15 & 221.1 \\
\hline 5 & $\mathrm{HB}$ & low & $\leq 10 \%$ & $\bmod$ & A & A & 46.2 & 7.69 & 228.2 \\
\hline 6 & $\mathrm{HB}$ & $\bmod$ & $>10 \%$ & dense & A & A & 38.8 & 6.49 & 194.5 \\
\hline 7 & $\mathrm{HB}$ & $\bmod$ & none & sparse & A & A & 70.7 & 9.24 & 186.1 \\
\hline 8 & $\mathrm{HB}$ & $\bmod$ & $\leq 10 \%$ & $\bmod$ & A & A & 51.0 & 7.26 & 166.2 \\
\hline 9 & $\mathrm{HB}$ & low & $\leq 10 \%$ & $\bmod$ & A & A & 52.8 & 7.73 & 135.5 \\
\hline 10 & $\mathrm{HB}$ & low & $\leq 10 \%$ & $\bmod$ & A & A & 60.8 & 8.29 & 118.9 \\
\hline 11 & $\mathrm{HB}$ & high & -- & -- & A & A & 60.1 & 8.65 & 104.0 \\
\hline 12 & $\mathrm{HB}$ & $\bmod$ & $>10 \%$ & $\bmod$ & A & A & 45.6 & 5.98 & 99.7 \\
\hline 13 & $\mathrm{HB}$ & high & $>10 \%$ & dense & A & A & 41.5 & 3.92 & 155.6 \\
\hline 14 & $\mathrm{HB}$ & $\bmod$ & -- & -- & A & A & 34.8 & 2.02 & 311.7 \\
\hline 15 & $\mathrm{HB}$ & $\bmod$ & $\leq 10 \%$ & $\bmod$ & A & $\mathrm{P}$ & 40.5 & 2.81 & 343.2 \\
\hline 16 & UN & low & $\leq 10 \%$ & sparse & A & $\mathrm{P}$ & 51.0 & 7.97 & 328.4 \\
\hline 17 & $\mathrm{HB}$ & $\bmod$ & none & dense & A & A & 67.2 & 9.74 & 327.4 \\
\hline 18 & $\mathrm{HB}$ & low & $\leq 10 \%$ & sparse & A & A & 51.2 & 6.70 & 315.1 \\
\hline 19 & $\mathrm{HB}$ & low & $\leq 10 \%$ & sparse & A & A & 51.2 & 5.56 & 316.2 \\
\hline 20 & $\mathrm{HB}$ & low & $\leq 10 \%$ & sparse & A & A & 52.3 & 7.07 & 300.7 \\
\hline 21 & UN & none & none & none & $\mathrm{P}$ & A & 55.3 & 9.39 & 268.6 \\
\hline 22 & UN & low & none & sparse & A & A & 56.7 & 8.47 & 265.5 \\
\hline 23 & UN & none & none & none & $\mathrm{P}$ & A & 54.1 & 10.18 & 256.6 \\
\hline 24 & $\mathrm{UN}$ & none & none & none & $\mathrm{P}$ & A & 54.9 & 11.58 & 251.8 \\
\hline 25 & UN & none & none & none & $\mathrm{P}$ & A & 53.6 & 5.86 & 258.2 \\
\hline 26 & UN & low & -- & sparse & A & A & 44.6 & 3.73 & 269.8 \\
\hline 27 & $\mathrm{HB}$ & $\bmod$ & -- & -- & A & A & 50.1 & 14.67 & 270.9 \\
\hline 28 & $\mathrm{HB}$ & $\bmod$ & $\leq 10 \%$ & $\bmod$ & A & A & 51.4 & 13.66 & 245.9 \\
\hline
\end{tabular}


Appendix 39. Habitat classifications for 17 camera drop sites on WNB terrace. Induration (Ind) was either hard-bottom (HB) or unconsolidated (UN). Roughness (Rough) was classified as none, low, moderate (mod), or high. Live coral and macroalgal cover could not be determined for sites (--) with severe camera kiting above the seafloor. Dense heart urchin aggregations and large features were categorized as present $(\mathrm{P})$ or absent (A). Distance and direction to NIH were calculated from the start drift coordinates to island center. Site 32 was surveyed twice (19 Apr 2011 and 19 Aug 2011), and on both dates the habitat classifications were identical. Loose rubble or talus also may have been present at sites $31,34-36,38,39,41$, and 42 .

\begin{tabular}{cccccccccc}
\hline Site & Ind & Rough & $\begin{array}{c}\text { Coral } \\
\text { cover }\end{array}$ & $\begin{array}{c}\text { Algal } \\
\text { cover }\end{array}$ & Urchins & Features & $\begin{array}{c}\text { Depth } \\
(\mathrm{m})\end{array}$ & $\begin{array}{c}\text { Distance } \\
(\mathrm{km})\end{array}$ & $\begin{array}{c}\text { Direction } \\
(\mathrm{deg})\end{array}$ \\
\hline 29 & HB & high & $\leq 10 \%$ & mod & A & A & 38.1 & 23.34 & 79.7 \\
30 & HB & high & -- & -- & A & A & 69.0 & 23.88 & 84.7 \\
31 & HB & high & $>10 \%$ & mod & A & A & 31.6 & 25.62 & 81.3 \\
32 & HB & high & $>10 \%$ & mod & A & A & 31.0 & 27.03 & 76.8 \\
33 & HB & high & $>10 \%$ & mod & A & A & 29.2 & 25.99 & 72.4 \\
34 & HB & low & $\leq 10 \%$ & sparse & A & A & 50.2 & 26.86 & 64.3 \\
35 & HB & low & none & mod & A & A & 53.9 & 28.79 & 61.6 \\
36 & UN & low & none & sparse & A & A & 50.3 & 29.72 & 61.7 \\
37 & HB & high & $\leq 10 \%$ & dense & A & P & 94.2 & 28.53 & 59.5 \\
38 & HB & high & $\leq 10 \%$ & mod & A & P & 66.2 & 32.24 & 57.4 \\
39 & HB & mod & none & mod & A & A & 51.3 & 31.36 & 59.7 \\
40 & UN & low & none & sparse & A & A & 48.5 & 31.45 & 61.6 \\
41 & HB & mod & none & mod & A & A & 50.8 & 32.64 & 59.8 \\
42 & UN & none & none & sparse & A & A & 46.0 & 32.95 & 61.6 \\
43 & HB & high & -- & -- & A & A & 65.3 & 32.78 & 87.8 \\
44 & HB & high & $\leq 10 \%$ & mod & A & A & 36.8 & 33.14 & 86.8 \\
45 & HB & mod & $\leq 10 \%$ & mod & A & A & 33.6 & 29.66 & 86.0 \\
\hline
\end{tabular}


Appendix 40. Relationship between depth and proportion of locations per area of influence for resident adults (RA) and all seals combined.

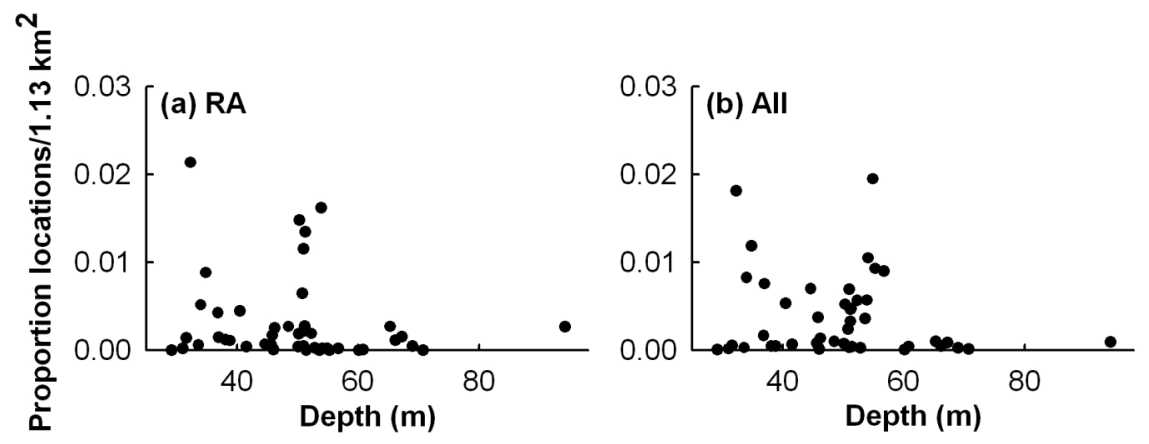




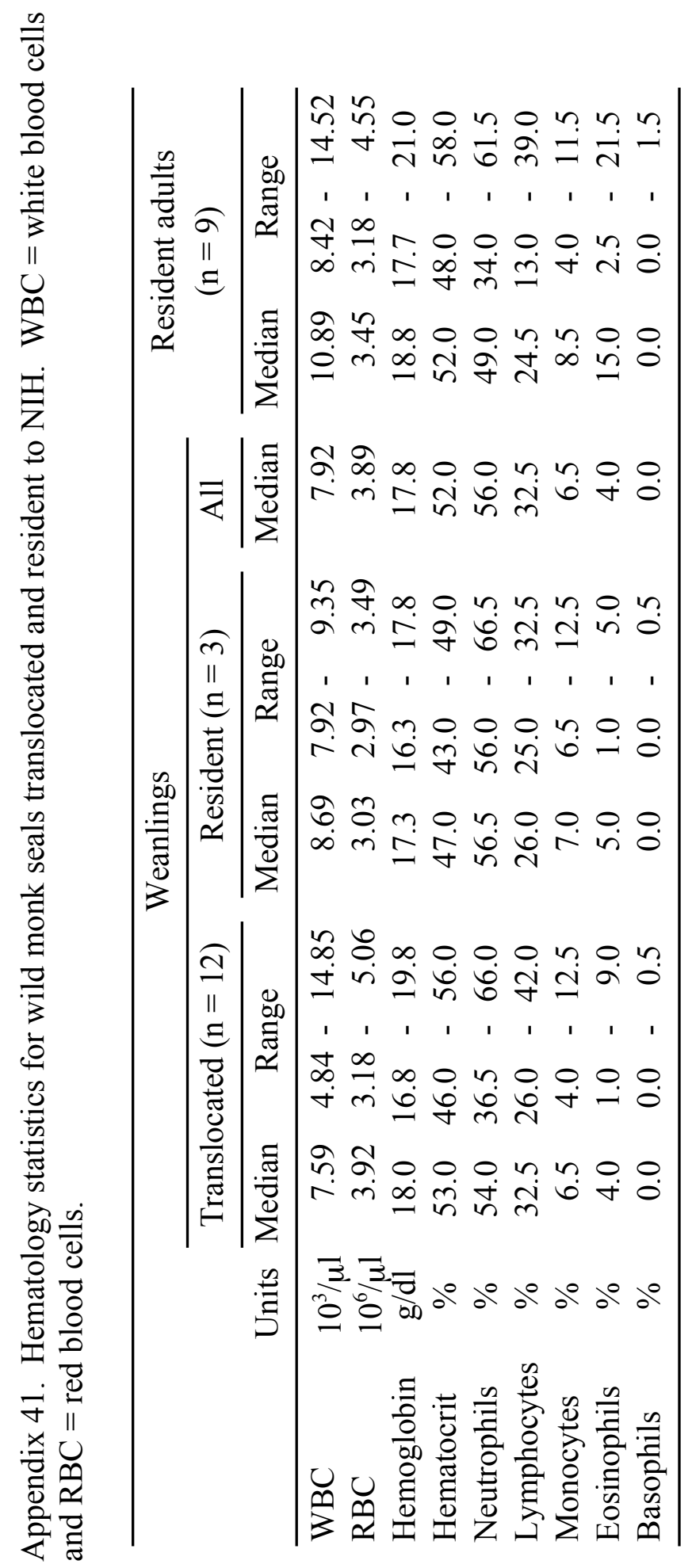


Appendix 42. Hematology values for each individual. Published reference ranges for weanling (RBC, HCT: Banish \& Gilmartin 1988; WBC differentials: Sloan 1999; ---) and non-weanling (HCT: Reif et al. 2004; WBC differentials: Aguirre 2000; - ) Hawaiian monk seals. $\mathrm{TW}=$ translocated weanlings, $\mathrm{RW}=$ resident weanlings, $\mathrm{RA}=$ resident adults, $\mathrm{RBC}=$ red blood cells, and $\mathrm{HCT}=$ hematocrit.
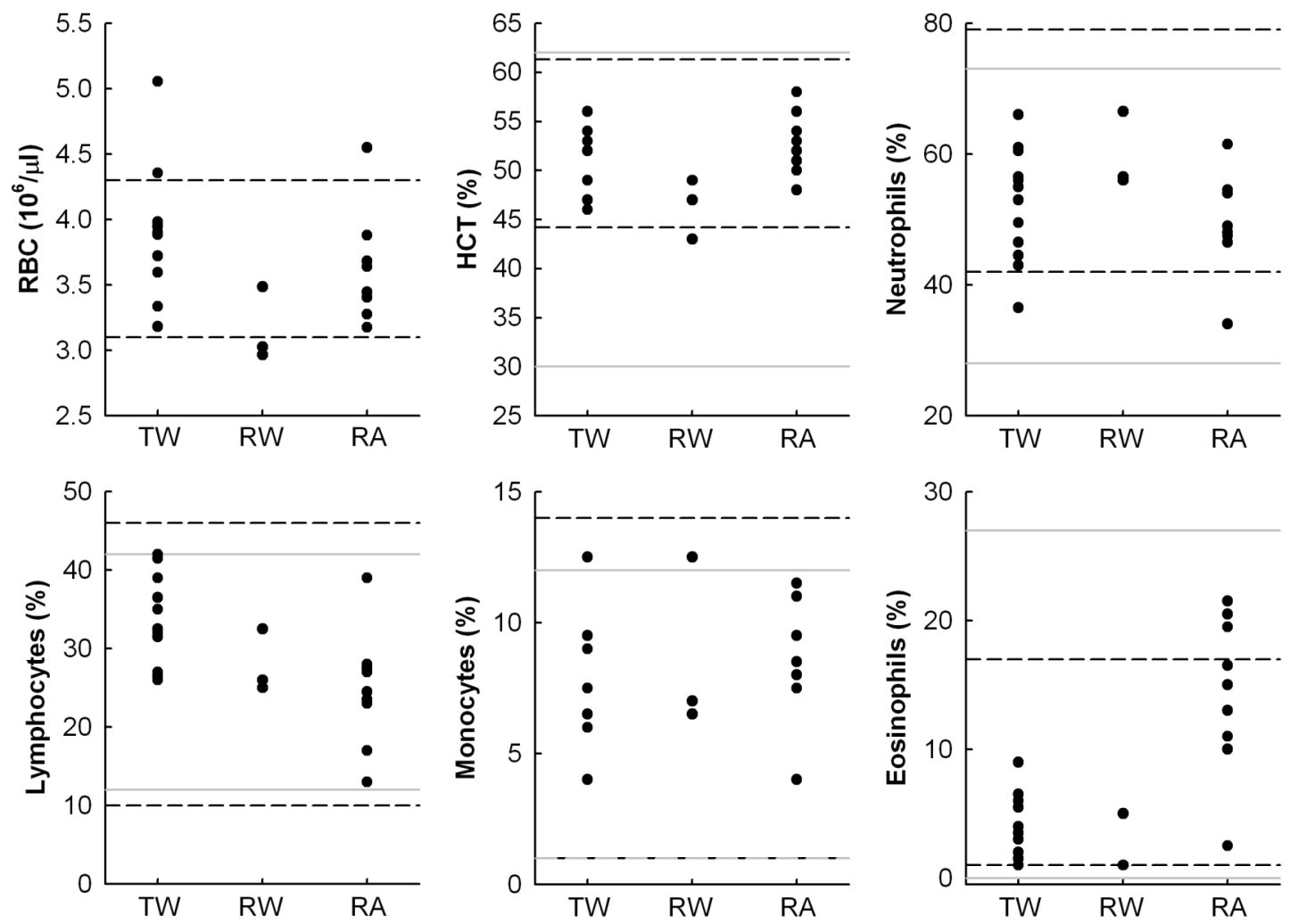

Aguirre A (2000) Health assessment and disease status studies of the Hawaiian monk seal (Monachus schauinslandi). NOAA, SWFSC Admin Rep H-00-01, US Department of Commerce

Banish LD, Gilmartin WG (1988) Hematology and serum chemistry of the young Hawaiian monk seal (Monachus schauinslandi). J Wildl Dis 24:225-230

Reif JS, Bachand A, Aguirre AA, Borjesson DL, Kashinsky L, Braun R, Antonelis G (2004) Morphometry, hematology, and serum chemistry in the Hawaiian monk seal (Monachus schauinslandi). Mar Mamm Sci 20:851-860

Sloan A (1999) Health determination, hematology, serum chemistry, and morphometrics of Hawaiian monk seals (Monachus schauinslandi) in rehabilitation. MS thesis, University of Hawaii, HI 


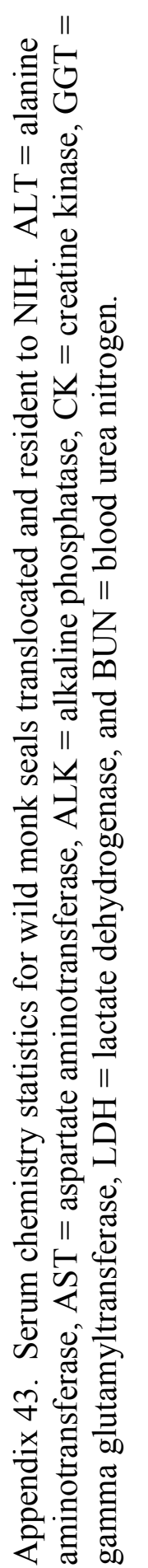

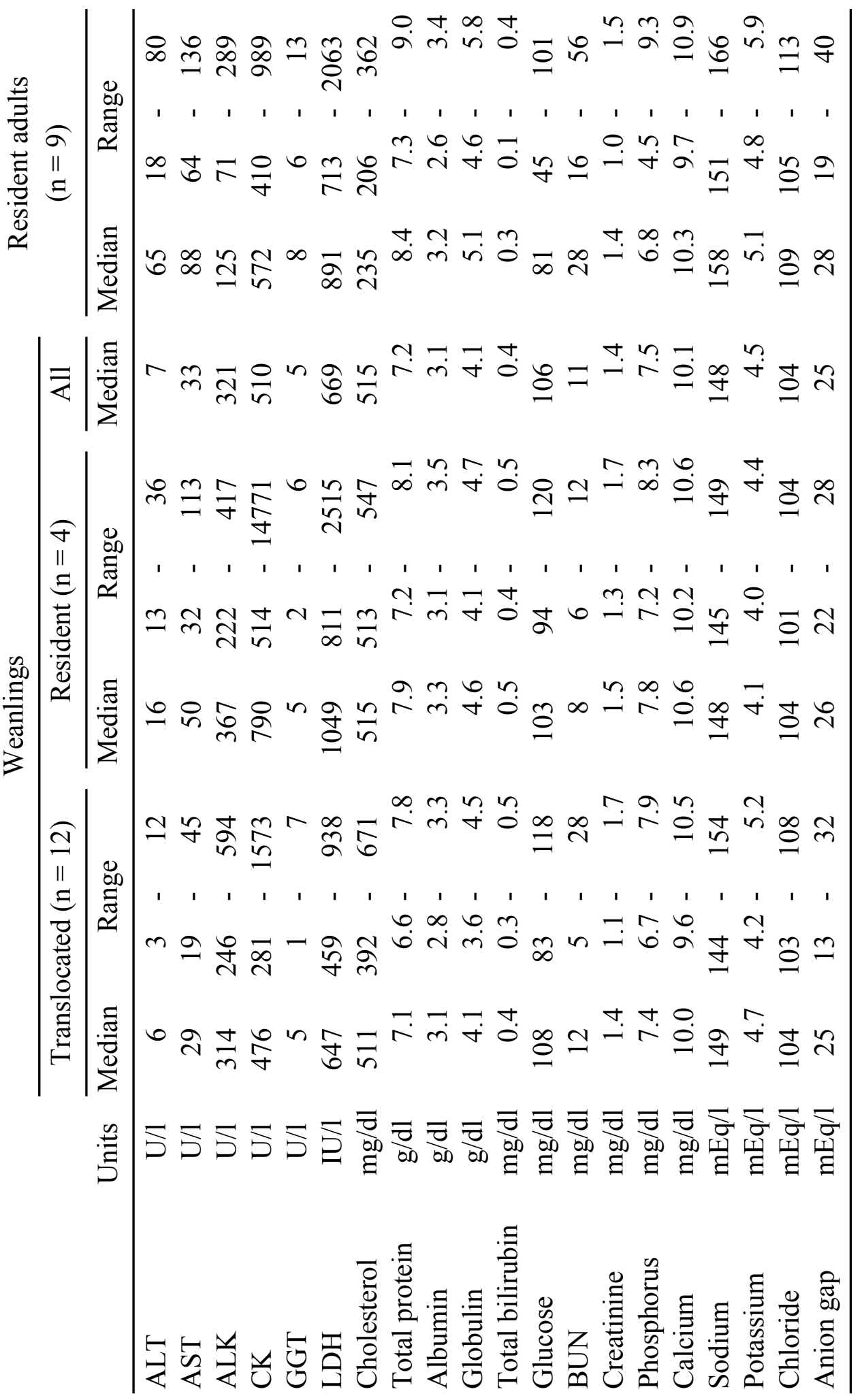




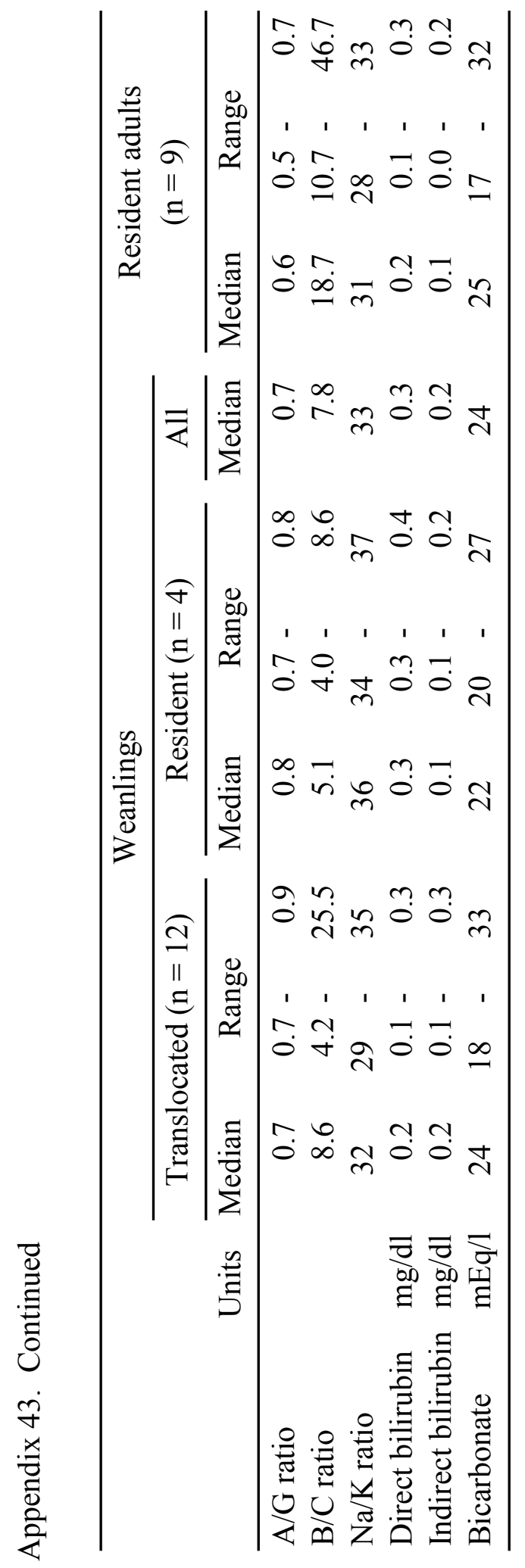


Appendix 44. Serum chemistry values for each individual. Published reference ranges for weanling (Banish \& Gilmartin 1988, except CK: Sloan 1999; ---) and non-weanling (Reif et al. 2004; -) Hawaiian monk seals. TW $=$ translocated weanlings, RW $=$ resident weanlings, $\mathrm{RA}=$ resident adults, $\mathrm{AST}=$ aspartate aminotransferase, $\mathrm{ALK}=$ alkaline phosphatase, $\mathrm{CK}=$ creatine kinase, $\mathrm{GGT}=$ gamma glutamyltransferase, $\mathrm{LDH}=$ lactate dehydrogenase, and $\mathrm{BUN}=$ blood urea nitrogen .
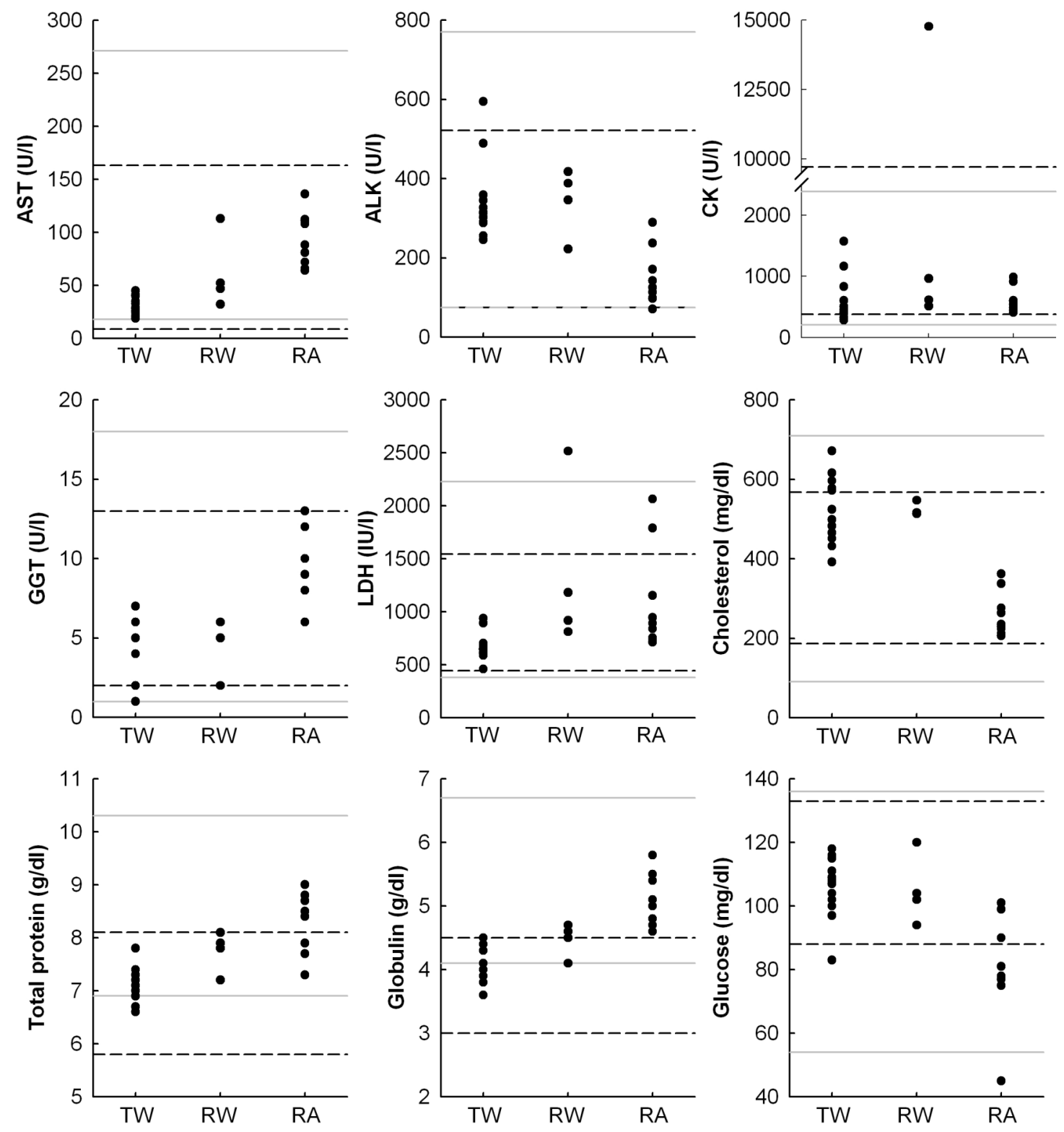
Appendix 44. Continued
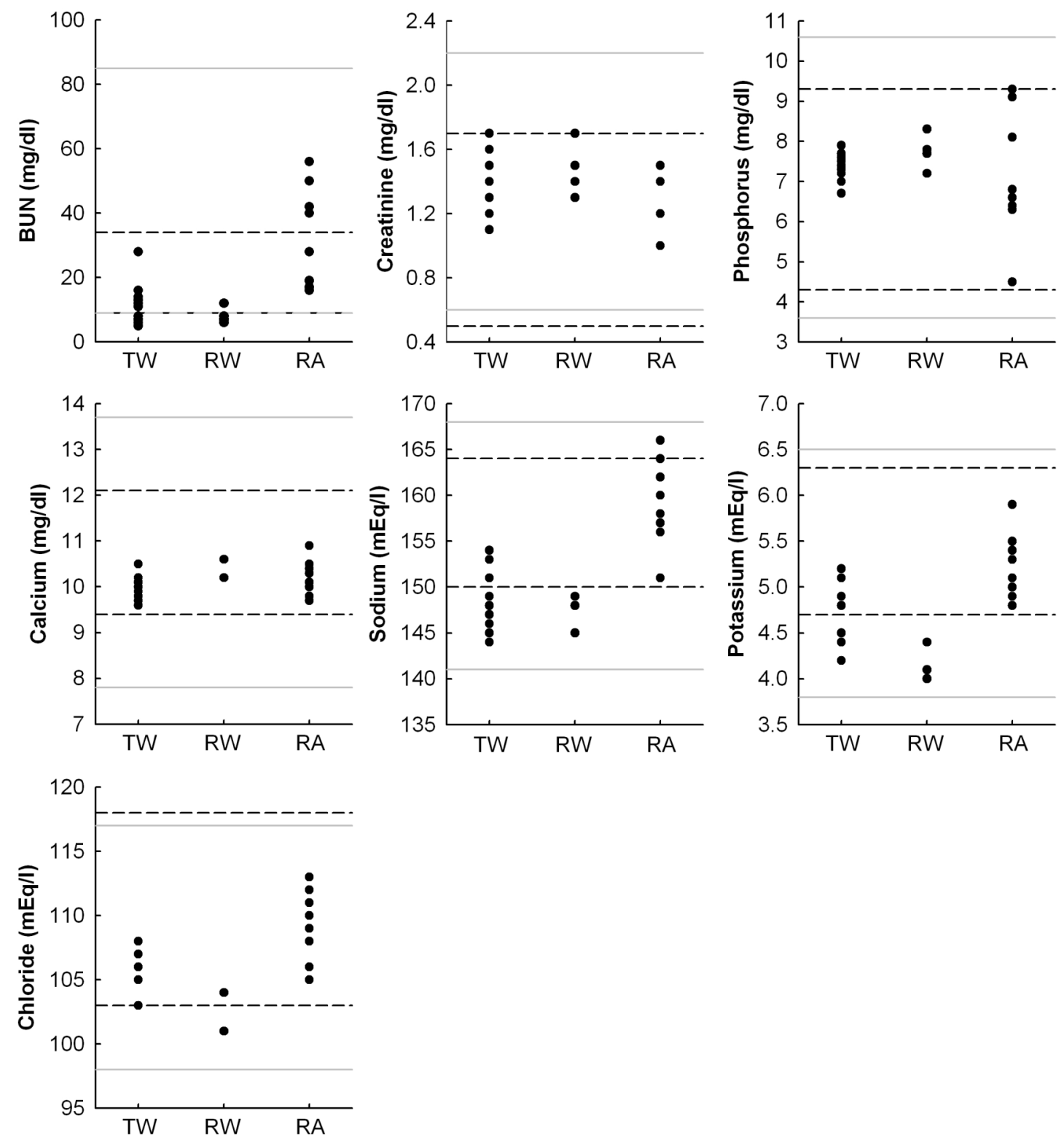

Banish LD, Gilmartin WG (1988) Hematology and serum chemistry of the young Hawaiian monk seal (Monachus schauinslandi). J Wildl Dis 24:225-230

Reif JS, Bachand A, Aguirre AA, Borjesson DL, Kashinsky L, Braun R, Antonelis G (2004) Morphometry, hematology, and serum chemistry in the Hawaiian monk seal (Monachus schauinslandi). Mar Mamm Sci 20:851-860 
Sloan A (1999) Health determination, hematology, serum chemistry, and morphometrics of Hawaiian monk seals (Monachus schauinslandi) in rehabilitation. MS thesis, University of Hawaii, HI 
Appendix 45. Last sighting date and location for re-sighted translocated and resident monk seals. Re-sights were through the end of the 2011 field season. NIH = Nihoa Island, $\mathrm{MHI}=$ main Hawaiian Islands, and FFS $=$ French Frigate Shoals .

\begin{tabular}{ccc}
\hline ID & Last sighting date & Last sighting location \\
\hline \multicolumn{2}{c}{ Translocated weanlings } \\
YW07 & 19 Aug 2011 & NIH \\
YW24 & 17 Nov 2010 & NIH \\
YW29 & 19 Aug 2010 & NIH \\
YA08 & 18 Nov 2010 & NIH \\
YA10 & 19 Aug 2010 & NIH \\
YA42 & 18 Nov 2010 & NIH \\
Resident weanlings & \\
RW62 & 14 May 2010 & NIH \\
RW64 & 17 Nov 2010 & NIH \\
RW68 & 19 Aug 2010 & NIH \\
RA50 & 15 Oct 2011 & MHI \\
RA52 & 19 Aug 2011 & NIH \\
RA54 & 17 Nov 2010 & NIH \\
RA58 & 02 Jun 2010 & NIH \\
Resident adults & \\
R2BY & 17 Nov 2010 & NIH \\
R5EE & 18 Nov 2010 & NIH \\
R5EG & 15 Jul 2011 & FFS \\
R5EI & 18 Nov 2010 & NIH \\
R5EP & 02 Jun 2010 & NIH \\
\hline
\end{tabular}


Appendix 46. Discriminant function scores for weaning body size. Scores for the translocated weanling (TW) seals and all non-translocated weanling seals born in 2008 and 2009 at French Frigate Shoals (FFS control) and Nihoa Island (NIH control) were overlaid with weaning body size group centroids (squares with same color coding).

Discriminant function 1 explained most of the variance in weaning body size whereas discriminant function 2 explained only $0.7 \%$ of the variance (canonical $r^{2}=0.002, x^{2}=$ $0.092, d f=4, p=0.762$ ). Arrow size represents the factor loading weight (function 1 loading values in text, axillary girth $(\mathrm{AG})$ function 2 loading $=0.665$, and dorsal standard length $(\mathrm{DSL})$ function 2 loading $=0.103$ ). Arrow direction indicates the relationship between each variable and discriminant function (e.g. greater AG and DSL associated with greater function 1 scores).

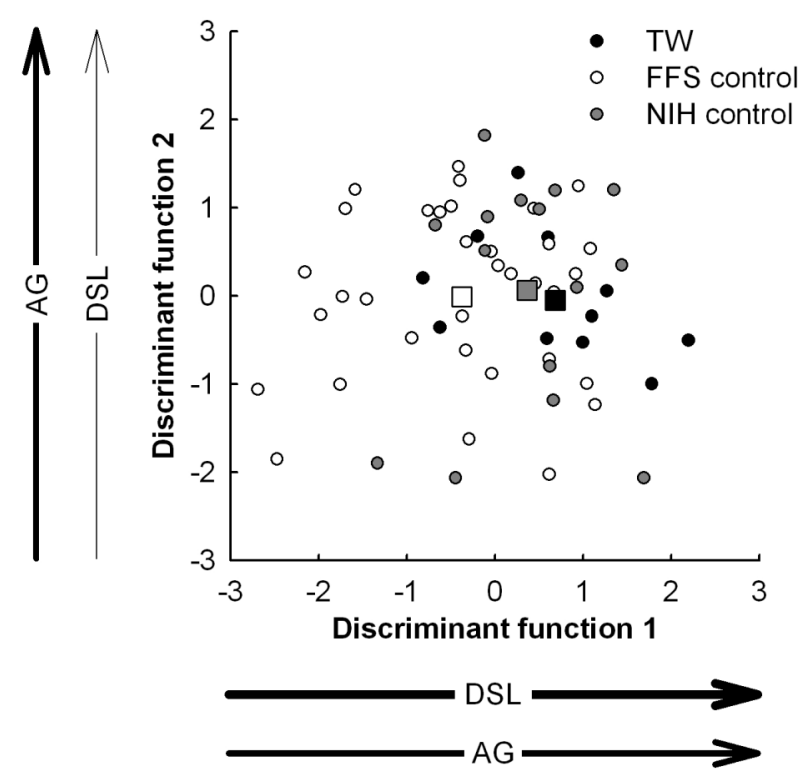


Appendix 47. Relationship between girth and first-year survivorship. Observed firstyear survival (a) and predicted probability of survival (b) for translocated weanling (TW) seals and all non-translocated weanling seals born in 2008 and 2009 at French Frigate Shoals (FFS control) and Nihoa Island (NIH control). The predicted probabilities were plotted as a response curve (black line) for the most parsimonious model that included only axillary girth (AG) and as individual points for each seal for the model that included $\mathrm{AG}+$ group. A predicted probability $\geq 0.5$ was classified as alive at age one.
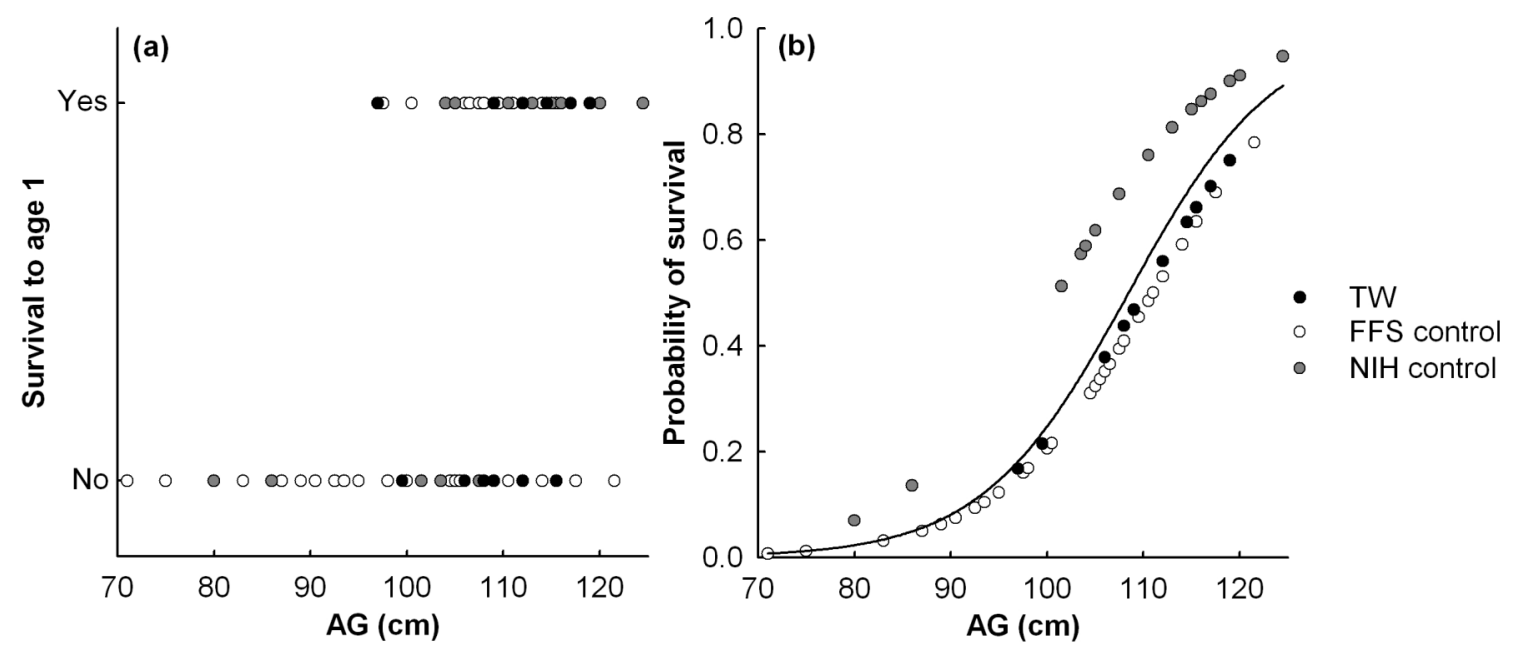
Appendix 48. First-year survivorship models for subset of weanling seals with axillary girth $(\mathrm{AG}) \geq 97 \mathrm{~cm}$. The change in $\mathrm{AIC}_{\mathrm{C}}(\triangle \mathrm{AIC} C)$ is relative to the best fitting model. The null model includes only the intercept term, $\mathrm{LL}=\log$ likelihood, $d f=$ degrees of freedom, $\mathrm{r}_{\mathrm{N}}^{2}=$ Nagelkerke-adjusted $\mathrm{r}^{2}$, and $\%$ correct $=$ percentage of corrected classified survival outcomes.

\begin{tabular}{lcccccc}
\hline & $\mathrm{LL}$ & $\mathrm{AIC}_{\mathrm{C}}$ & $\Delta \mathrm{AIC}_{\mathrm{C}}$ & $d f$ & $\mathrm{r}_{\mathrm{N}}{ }^{2}$ & $\%$ correct \\
\hline $\mathrm{AG}$ & -32.682 & 69.609 & & 45 & 0.123 & 61.5 \\
$\mathrm{AG}+$ group & -31.160 & 71.172 & 1.563 & 43 & 0.192 & 61.5 \\
Group & -32.612 & 71.723 & 2.114 & 44 & 0.126 & 61.5 \\
AG + sex + group & -31.123 & 73.550 & 3.941 & 42 & 0.194 & 61.5 \\
Null model & -35.197 & 72.473 & 2.864 & 46 & -- & 53.8 \\
\hline
\end{tabular}

